12

13

\title{
Rapid adaptation of endocytosis, exocytosis and eisosomes after an acute increase in membrane tension in yeast cells
}

Joël Lemière ${ }^{a, b, d^{*}}$, Yuan Ren $^{\mathrm{a}, \mathrm{b},{ }^{*}}$, Julien Berro $^{\mathrm{a}, \mathrm{b}, \mathrm{c}, \S}$

a Department of Molecular Biophysics and Biochemistry, Nanobiology Institute, Yale University, New Haven, CT, USA

${ }^{\mathrm{b}}$ Nanobiology Institute, Yale University, West Haven, CT 06516, USA

${ }^{\mathrm{c}}$ Department of Cell Biology, Yale University School of Medicine, New Haven, CT 06520, USA

d Current address: UCSF, Department of Cell and Tissue Biology, San Francisco, CA, USA

*Authors contributed equally

$\S$ Contact: julien.berro@yale.edu 
During clathrin-mediated endocytosis in eukaryotes, actin assembly is required to overcome large membrane tension and turgor pressure. However, the molecular mechanisms that enable the actin machinery to adapt to varying membrane tension remain unclear. Here, we used quantitative microscopy to determine that, upon increased membrane tension, the endocytic actin machinery of fission yeast cells rapidly adapts. We also demonstrate that cells rapidly reduce their membrane tension using three parallel mechanisms. In addition to using their cell wall for mechanical protection, yeast cells disassemble eisosomes to buffer moderate changes in membrane tension on a minute time scale. Meanwhile, a temporary reduction of the rate of endocytosis for 2 to 6 minutes, and an increase in the rate of exocytosis for at least 5 minutes allow cells to add large pools of membrane to the plasma membrane. Our study sheds light on the tight connection between membrane tension regulation, endocytosis and exocytosis.

\section{Introduction}

During clathrin-mediated-endocytosis (CME), the cell plasma membrane undergoes a dramatic change in topology to form an invagination that is subsequently pinched off into a vesicle. During this process, the endocytic machinery has to overcome the forces produced by membrane tension and the osmotic pressure that oppose membrane deformation and engulfment. In yeast cells, these resisting forces are particularly large because their internal turgor pressure is high, ranging from $\sim 0.6 \mathrm{MPa}$ for Saccharomyces cerevisiae to more than $1 \mathrm{MPa}$ for Schizosaccharomyces pombe (Davì et al., 2018; Minc et al., 2009; Schaber et al., 2010). Consequently the formation of a vesicle requires several thousands of $\mathrm{pN}$ (Dmitrieff and Nédélec, 2015; Ma and Berro, 2020).

Previous studies have shown that actin dynamics are required for productive endocytosis in yeast (Aghamohammadzadeh et al., 2014; Basu et al., 2013; Carlsson and Bayly, 2014; Lacy et al., 2018; Palmer et al., 2015) and in mammalians cells when membrane tension is high (Aghamohammadzadeh and Ayscough, 2009; Boulant et al., 2011; Hassinger et al., 2017), or when membrane scission proteins are absent (Ferguson et al., 2009). Actin assembly at the endocytic site is believed to provide the forces that overcome turgor pressure and membrane tension to deform the plasma membrane, but the precise mechanisms of force production remain unknown. We also lack a quantitative understanding of the regulation of actin dynamics in response to membrane tension and turgor pressure changes. We expect that a better quantitative characterization of this response will allow us to infer the molecular mechanisms of force production and force sensing during clathrinmediated endocytosis.

In this study, we applied hypotonic shocks to fission yeast cells to determine how the actin machinery responds to increased membrane tension and turgor pressure during clathrin-mediated endocytosis. After a hypotonic shock, the difference in osmolarity inside and outside the cell instantaneously increases the turgor pressure and the membrane tension. Since cell membranes are virtually unstretchable, yeast cells must rapidly adapt their membrane tension while they let 
water flow inward to equilibrate their cytosol osmolarity to the new environment (Hohmann, 2015, 2002; Suescún-Bolívar and Thomé, 2015).

The mechanisms by which membrane tension is regulated are not fully understood. The yeast cell wall is believed to buffer abrupt changes in turgor pressure thanks to its high stiffness of $\sim 50 \mathrm{MPa}$ (Atilgan et al., 2015). In addition, similarly to mammalian cells' caveolae which change shape or disassemble in response to increased membrane tension, yeast eisosomes can also disassemble when cells without a cell wall, called protoplasts, are placed in low osmolarity media (Kabeche et al., 2015; Parton et al., 2019; Sinha et al., 2011). However, it remains unknown how eisosomes may regulate plasma membrane tension in intact cells, and whether eisosomes disassembly directly influences cellular processes such as CME.

Fission yeast is an ideal model system to quantitatively study the regulation mechanisms of membrane tension and its influence on the endocytic machinery. First, because yeast turgor pressure is high, actin is required for CME. Second, contrary to mammalian cells, yeast cells are devoid of any adhesion machinery or actin cortex, which usually complicates membrane tension manipulation and result interpretation. Last, quantitative microscopy methods developed in fission yeast are able to uncover fine regulations of the endocytic machinery (Arasada and Pollard, 2011; Berro et al., 2010; Berro and Lacy, 2018; Berro and Pollard, 2014a, 2014b; Chen and Pollard, 2013; Sirotkin et al., 2010).

To probe the contribution of each possible mechanisms of membrane tension regulation and their influence on $\mathrm{CME}$, we submitted yeast cells with or without a cell wall to different hypotonic shocks. Using quantitative fluorescence microscopy, we showed that, on the one hand, actin assembly adapts to increased membrane tension to allow endocytosis to proceed, and, on the other hand, yeast cells rapidly reduce their membrane tension by a) disassembling eisosomes, b) reducing their rate of endocytosis and c) increasing their rate of exocytosis. 
97

98

99

100

101

102

103

104

105

106

107

108

109

110

111

112

113

114

115

116

117

118

119

120

121

122

123

124

125

126

127

128

129

130

131

132

133

134

135

136

137

138

139

140

141

142

143

144

\section{Results}

\section{Clathrin-mediated endocytosis in wild-type walled cells is robust over a wide range of chronic and acute changes in media osmolarity}

To monitor actin dynamics during clathrin-mediated endocytosis, we imaged fission yeast cells expressing the actin filament crosslinking protein fimbrin (Fim1p) tagged with a monomeric enhanced green fluorescent protein (mEGFP), hereafter called Fim1p-mEGFP (Figure 1A, 1B and 1C). Fimbrin is a bona fide marker for endocytosis in yeast since it has spatial and temporal co-localization with the classical endocytic marker End4p (the fission yeast homolog of mammalian Hip1R and budding yeast Sla2) during endocytosis (Figure 1D, 1E). Fimbrin's time of appearance, disappearance, peak number of molecules and spatial localization follows those of actin in wild-type and all mutants tested so far (Arasada et al., 2018; Berro and Pollard, 2014b; Chen and Pollard, 2013; Sirotkin et al., 2010). Fimbrin is the most abundant endocytic proteins that is fully functional when tagged with a fluorescent protein at either $\mathrm{N}$ - or $\mathrm{C}$-terminal, which makes it a more robust marker for actin dynamics than tagged actin or actin-binding markers such as LifeAct or calponin-homology domains, because they require over-expression which is difficult to control precisely in fission yeast, and potentially creates artifacts (Courtemanche et al., 2016; Suarez et al., 2015). We optimized our imaging protocols, and improved tracking tools and temporal super-resolution alignment methods (Berro and Pollard, 2014a) to a) easily collect hundreds of endocytic events in an unbiased manner and b) achieve high reproducibility between different samples, fields of view and days of experiment (Figure 1F, 1G). These improvements in our quantitative microscopy protocol have allowed us to detect small differences between mutants or conditions that would be missed with previous methods. We confirmed that Fim1p accumulates at endocytic sites for about 10 seconds, and then disassembles while the vesicle diffuses away from the plasma membrane (Figure 1F, 1G) (Sirotkin et al., 2010; Skau et al., 2011). As a convention, the peak of Fim1p is set to time $0 \mathrm{~s}$ and corresponds to vesicle scission in intact wild-type cells (Berro and Pollard, 2014a, 2014b; Sirotkin et al., 2010). In the rest of the paper, intact cells with a cell wall will be referred to as "walled cells", and cells devoid of a cell wall will be referred to as "protoplasts".

We aimed to increase the tension of cells' plasma membrane by rapidly reducing media osmolarity, referred to as acute hypotonic shock. To prevent artifacts due to nutrient concentration changes, we supplemented Edinburgh Minimum Media (EMM5S) with varying sorbitol concentrations (0 to $1.2 \mathrm{M})$. Before performing hypotonic shocks, we exposed cells to this media for more than 15 minutes. In the rest of the paper, we will refer to this experimental condition as steady state at X M or chronic exposure to $X \mathrm{M}$ sorbitol, where $X$ is the sorbitol concentration. To perform acute hypotonic shocks, we used a microfluidic system to rapidly exchange the steady state media with media containing a lower sorbitol concentration, hereafter noted $\Delta \mathrm{P}=-\mathrm{Y} M$ where $\mathrm{Y}$ is the difference in media osmolarity (note that the pressure $P^{*}$ in Pascal is related to $P$ in Molar as $P^{*}=P \cdot R T \sim 2.45 \cdot 10^{6} \cdot P$, where $R$ is the gas constant and $T$ the absolute temperature) (Figure $2 \mathrm{~A}$ ). For all tested osmolarities at steady state in walled wild-type cells, we observed no significant difference in the dynamics of fimbrin recruitment or disassembly, maximum molecule number or endocytic patch movements (Figure 2B). Our results indicate that wild-type walled cells have adaptation mechanisms for chronic exposure to a wide range of osmolarities, which allows them to perform CME in a highly reproducible manner. 
We then tested the robustness of the endocytic actin machinery when cells experienced a hypotonic shock, which aimed to abruptly increase the tension of their plasma membrane. To observe the highest possible effect, we imaged cells grown at steady state in 1.2 $\mathrm{M}$ sorbitol and rapidly exchanged the media with a buffer free of sorbitol (Figure $2 \mathrm{~A}$ and $2 \mathrm{E}$ ), therefore performing an acute hypotonic shock of $\triangle \mathrm{P}=-$ 1.2 M. Despite the high hypotonic shock, which represents a $\sim 3 \mathrm{MPa}$ drop in pressure, CME proceeded quite similarly to steady state conditions (Figure 2C, 2D and $2 \mathrm{E}$ ). The maximum number of fimbrin proteins was the same before and after the hypotonic shock, but fimbrin assembly and disassembly were $\sim 15 \%$ faster after the shock (Figure 2E).

\section{Eisosomes mitigate the response of the endocytic machinery to acute and chronic changes in media osmolarity}

The robustness of the endocytic process under a wide range of chronic and acute exposure to different media osmolarity suggests that fission yeast has mechanisms that rapidly regulate plasma membrane tension. Previous studies proposed that eisosomes, furrows at the inner surface of the plasma membrane, have a mechanoprotective role under increased membrane tension in fungi, similar to the protective role of caveolae in endothelial cells (Cheng et al., 2015; Kabeche et al., 2015; Lo et al., 2016; Sens and Turner, 2006; Sinha et al., 2011). Because loss of Pil1p, the core eisosome component, is sufficient to prevent eisosome assembly (Kabeche et al., 2011; Olivera-Couto et al., 2011; Ziółkowska et al., 2011), we repeated our experiments in cells lacking the gene coding for Pil1p (pil14) (Figure 3).

Dynamics of Fim1p during CME for wild-type and pil1 $\Delta$ walled cells at steady state in media free of sorbitol were identical (Figure 3 Supplement 1). However, at steady state in media with high sorbitol concentration, cells lacking eisosomes recruited slightly fewer fimbrin molecules to endocytic patches than wild-type cells (Figure $3 \mathrm{~A}$ and $\mathrm{B}$ ). The maximum number of Fim 1p assembled at CME sites in pil1 $\Delta$ cells in buffer containing $0.8 \mathrm{M}$ and $1.2 \mathrm{M}$ sorbitol was $10 \%$ and $17 \%$ lower, respectively. Within the first two minutes of an acute hypotonic shock from $1.2 \mathrm{M}$ sorbitol to $0 \mathrm{M}(\triangle \mathrm{P}=-1.2 \mathrm{M})$, the maximum number of Fim1p increased by $30 \%$, while its timing was shortened by $\sim 30 \%$ compared to steady-state (Figure $3 \mathrm{C} \& 3 \mathrm{D}$ ). Four minutes after the hypotonic shock, the dynamics of fimbrin stabilized at its steady state dynamics in $0 \mathrm{M}$ sorbitol (Figure 3B \& 3D). Overall, our data show that the endocytic actin machinery in cells lacking eisosomes is more sensitive to acute and chronic changes in media osmolarity than in wild-type cells.

\section{Eisosomes participate in the regulation of protoplasts' membrane tension during hypotonic shocks}

The yeast cell wall plays a role in the maintenance of cell integrity under extreme conditions, thanks to its high stiffness of $\sim 50 \mathrm{MPa}$ (Atilgan et al., 2015). We hypothesized that the cell wall prevents large variations in membrane tension under hypotonic shocks, which would explain why endocytosis in wild-type walled cells remains virtually unchanged in the extreme conditions we tested (Figure 2E). Hence, to exclude the effect of the cell wall, we reiterated our experiments using protoplasts instead of intact cells.

First, we characterized how the removal of the cell wall affects eisosomes' reorganization and $\mathrm{CME}$. We used a protocol that allowed us to manipulate protoplasts for up to $\sim 1$ hour after their formation, since they remain void of cell wall for about 3 hours (Flor-Parra et al., 2014). Because protoplasts are more fragile than 
195 walled cells, they were prepared in media containing 0.25 to $1.2 \mathrm{M}$ sorbitol to balance 196 turgor pressure and prevent cells from bursting (Basu et al., 2013; Kabeche et al., 197 2015; Stachowiak et al., 2014), and were imaged 15 minutes later, once they 198 reached steady state.

199 Our data show that endocytic patches and eisosomes in protoplasts at steady 200 state in $1.2 \mathrm{M}$ sorbitol are qualitatively similar to those in walled cells (Figure 4A) and 201 the cellular concentration of Pi1lp is the same in both conditions (Figure 4 202 Supplement 1A). However, the surface area of the protoplasts' plasma membrane 203 covered by eisosomes decreased with decreasing media osmolarity at steady state 204 (Figure 4B and 4C), and correlated with increasing cell volume (Figure 4 205 Supplement 1B). This result confirms previous results (Kabeche et al., 2015) showing that eisosomes are disassembled in media with
of eisosomes may reduce membrane tension.

To test whether membrane tension is indeed buffered by eisosomes, we measured membrane tension using a micropipette aspiration assay (Figure 4D). At steady state in $0.8 \mathrm{M}$ sorbitol, the membrane tension was $4.5 \pm 1.410^{-4} \mathrm{~N} \cdot \mathrm{m}^{-1}$ for wildtype protoplasts and $3.9 \pm 1.310^{-4} \mathrm{~N} \cdot \mathrm{m}^{-1}$ for pil1 $\Delta$ protoplasts (Figure 4E). We then repeated these measurements within 5 minutes after inducing a hypotonic shock of $\Delta \mathrm{P}=-0.2 \mathrm{M}$. We observed a 1.6-fold increase in membrane tension for wild-type protoplasts $\left(7.3 \pm 2.1 \quad 10^{-4} \mathrm{~N} \cdot \mathrm{m}^{-1}\right)$ and a 4.5 -fold increase for protoplasts lacking eisosomes $\left(17.4 \pm 6.110^{-4} \mathrm{~N} \cdot \mathrm{m}^{-1}\right)$. This result demonstrates that eisosomes participate in the adjustment of plasma membrane tension.

To confirm that eisosomes disassemble in protoplasts after a hypotonic treatment (Kabeche et al., 2015), and quantitatively characterize this disassembly, we measured the temporal evolution of the decrease in surface area covered by eisosomes after an acute hypotonic shock of $\Delta \mathrm{P}=-0.2 \mathrm{M}$ (Figure $4 \mathrm{H}$ and $4 \mathrm{I}$ ). Eisosomes disassembled rapidly after hypotonic shock, dropping to $\sim 50 \%$ of the surface area covered by eisosomes before the shock within $5 \mathrm{~min}$, indicating a fast response to counteract changes in membrane tension.

\section{CME in protoplasts is sensitive to chronic changes in osmolarity}

Endocytosis in wild-type protoplasts at steady state in medium containing 0.4 or $0.8 \mathrm{M}$ sorbitol was able to proceed normally by recruiting almost the same number of fimbrin molecules as in walled cells, but with a slightly longer timing (Figure 4F). In contrast, in medium with $1.2 \mathrm{M}$ sorbitol, the timing of fimbrin recruitment was dramatically longer, and endocytosis failed to proceed normally, as reported by the virtually null speed of patches during the entire time fimbrin was present at the endocytic site (Figure 4F). Cells lacking eisosomes showed very similar phenotypes but endocytosis started failing at $0.8 \mathrm{M}$ sorbitol (Figure $4 \mathrm{G}$ ).

At $0.25 \mathrm{M}$ sorbitol, both wild-type and pil1 10 protoplasts were able to perform endocytosis but required a larger amount of Fim1p (Figure 4F and 4G). In these conditions, the eisosomes covered only half of the plasma membrane surface area they cover at $0.4 \mathrm{M}$ sorbitol (Figure $4 \mathrm{~B}$ and $\mathrm{C}$ ) and our data suggest the plasma membrane was under high tension (Figure 4E). This result indicates that during $\mathrm{CME}$ the actin machinery is able to adapt to mechanical cues by mechanisms that are independent of the cell wall.

For both wild-type and pil1 $1 \Delta$ protoplasts in $0.4 \mathrm{M}$ sorbitol, the temporal evolution of the number of fimbrin molecules and the speed of patches were close to the same metrics measured in walled cells in media without sorbitol (Figure 4F and 4G). These results suggest that the osmotic pressure at these concentrations, which are 
245 equivalent to a pressure of $1 \mathrm{MPa}$, is close to the naturally maintained turgor

246 pressure of walled fission yeast cells, in good agreement with previous

247 measurements (Minc et al., 2009). Therefore, to keep protoplasts in conditions close

248 to walled cells, the steady state media used in our following experiments on

249 protoplasts contained $0.4 \mathrm{M}$ sorbitol.

250

251

252

253

254

255

256

257

258

259

260

261

262

263

264

265

266

267

268

269

270

271

272

273

274

275

276

277

In protoplasts, eisosomes buffer moderate hypotonic shocks, and the endocytic actin machinery rapidly adapts to increases in membrane tension

To characterize the adaptation of the endocytic actin machinery to a rapid increase in turgor pressure and membrane tension, we repeated our acute hypotonic shocks $(\Delta \mathrm{P}=-0.05 \mathrm{M},-0.1 \mathrm{M}$ or $-0.2 \mathrm{M})$ on protoplasts initially at steady state in media containing $0.4 \mathrm{M}$ sorbitol. After low $(\Delta \mathrm{P}=-0.05 \mathrm{M})$ and medium $(\Delta \mathrm{P}=-0.1 \mathrm{M})$ acute shocks in wild-type protoplasts, we did not observe any stalled endocytic events when cells started the recruitment of the actin machinery, endocytosis proceeded to successful completion (Figure 5A, 5B, 5C and Figure 5 Supplement 3). The recruitment of fimbrin did not significantly change over time. In contrast, two minutes after a $\Delta \mathrm{P}=-0.2 \mathrm{M}$ shock, endocytic sites recruited $20 \%$ more fimbrin and it took $\sim 25 \%$ longer to perform endocytosis (Figure 5C, 5D, and Figure 5 Supplement 3). The actin machinery restored its steady state behavior less than 4 minutes after the shock (Figure 5D).

We repeated these experiments with pil1 $1 \Delta$ protoplasts to eliminate the role of eisosomes in the reduction of membrane tension during hypotonic shocks. Immediately ( 0 minutes) after the lowest hypotonic shock tested $(\Delta P=-0.05 M)$, fimbrin recruitment took slightly longer and the number of proteins recruited was higher than at steady state (Figure 5E, 5F and 5G, Figure 5 Supplement 4). While fimbrin restored its steady-state dynamics in less than 4 minutes after high acute hypotonic shock $(\triangle P=-0.2 \mathrm{M})$ in wild-type protoplasts (Figure $5 \mathrm{D})$, recovery of fimbrin dynamics to its steady state behavior in pil1 $\Delta$ protoplasts occurred over 10 minutes, even for the most modest hypotonic shock, $\Delta \mathrm{P}=-0.05 \mathrm{M}$ (Figure $5 \mathrm{G}$ ). The changes in fimbrin dynamics in pil1 $\Delta$ protoplasts became increasingly larger for $\Delta P=-0.1 \mathrm{M}$ and $\Delta \mathrm{P}=-0.2 \mathrm{M}$ hypotonic shocks - endocytic sites assembled a peak number of fimbrin respectively $\sim 25 \%$ and $\sim 50 \%$ larger and took $\sim 85 \%$ and $\sim 50 \%$ longer. In addition, most cells were unable to survive more than two minutes after these high hypotonic shocks (Figure 6A, 6B, 6C and Figure 6 Supplement 1), which prevented us from determining how the actin machinery recovers after large hypotonic shocks in pil1 $\triangle$ protoplasts.

Wild-type protoplasts at steady state in $0.25 \mathrm{M}$ sorbitol contain significantly fewer assembled eisosomes despite expressing normal amounts of Pil1p (Figure 4B and 4C). We took advantage of this condition to test whether the absence of eisosomes structures at the plasma membrane and not the absence of the protein Pil1p is responsible for changes in actin dynamics after an acute hypotonic shock. We subjected wild-type protoplasts at steady state in $0.25 \mathrm{M}$ sorbitol to an acute hypotonic shock of $\Delta \mathrm{P}=-0.1 \mathrm{M}$ (Figure $5 \mathrm{H}$ and $5 \mathrm{I}$ ). Two minutes after the shock, endocytic sites accumulated $73 \%$ more fimbrin and took $\sim 60 \%$ longer (Figure $5 \mathrm{H}$, Figure 5 Supplement $5 \mathrm{~A}$ ). This behavior was nearly identical to fimbrin dynamics in pil1 $\mathrm{p}$ protoplasts under the same conditions (Figure 5I, Figure 5 Supplement 5B). Moreover, most wild-type and pil1 $\Delta$ protoplasts were unable to survive longer than 4 minutes after these high hypotonic shocks (Figure 5 Supplement $5 \mathrm{C}$ ). This result further demonstrates that the presence of assembled eisosomes at the plasma 
294 membrane is indeed responsible for the adaptation of cells to acute hypotonic

295

296

297

298

299

300

301

302

303

304

305

306

307

308

309

310

311

312

313

314

315

316

317

318

319

320

321

322

323

324

325

326

327

328

329

330

331

332

333

334

335

336

337

338

339

340

341

342

343 shocks, and the presence of Pil1p in the cytoplasm is not sufficient for this response.

Altogether, these series of experiments demonstrate that a) eisosomes protect protoplasts from changes in their membrane tension, but only to a small extent, b) without eisosomes, protoplasts can withstand only minor increase in their membrane tension, c) the endocytic actin machinery adapts to compensate the increase in membrane tension, and d) actin dynamics restores its steady state behavior within a few minutes, providing the protoplasts survived the hypotonic shock.

\section{Eisosomes protect the integrity of walled cells during consecutive osmotic shocks}

We observed that a significant number of both wild-type and pil1 $\Delta$ protoplasts died after osmotic shocks, and the percentage of pil1 $1 \Delta$ protoplasts that remained alive was significantly smaller than for wild-type protoplasts even under moderate shocks $\triangle \mathrm{P}$ of $-0.05 \mathrm{M},-0.1 \mathrm{M}$ and $-0.2 \mathrm{M}$ (Fig. 6A-C). In contrast, we found that both wild-type and pil1 $\Delta$ walled cells can survive a single hypotonic shock of $\Delta P=-1.2 \mathrm{M}$, which initially led us to think that eisosomes only have a minor protective role in walled cells. However, we noticed that subsequent osmotic shocks lead to higher mortality of pil $1 \Delta$ compare to wild-type walled cells. While almost all the wild-type walled cells remained alive after several shocks, around $10 \%$ of pil1 $1 \Delta$ walled cells died after each subsequent shock (Fig. 6D-F; supplementary video 1 and 2). These results demonstrate that, even in walled cells, eisosomes exert a protective role, likely by buffering sudden changes in membrane tension.

\section{Membrane tension and eisosomes modulate the rate of endocytosis in cells}

The fast recovery of the actin machinery after an acute change in turgor pressure and membrane tension (Figures 5D and 5G) cannot be explained by the sole release of membrane via eisosome disassembly which happens on a slightly shorter timescale and releases only a small surface area of membrane (Figure $4 \mathrm{H}$ and $4 \mathrm{I}$ ). We hypothesized that a decrease in the number of endocytic events happening in the cell over the same period of time would gradually increase the surface area of the plasma membrane, and therefore reduce membrane tension. We measured the endocytic density, i.e. the number of endocytic events in a cell normalized by the cell length, in wild-type and pil1 $\Delta$ cells after a hypotonic shock using a ratiometric method (Berro and Pollard, 2014a). For all shocks tested in wild-type ( $\triangle \mathrm{P}=-0.05 \mathrm{M},-0.1 \mathrm{M}$, $0.2 \mathrm{M})$ and pil1 $\Delta$ protoplasts $(\Delta \mathrm{P}=-0.025 \mathrm{M},-0.05 \mathrm{M},-0.1 \mathrm{M})$ initially at steady state in $0.4 \mathrm{M}$ sorbitol, the endocytic density in protoplasts significantly decreased immediately after the hypotonic shock (Figure 7A). The difference increased for increasing hypotonic shocks, up to $36 \%$ for wild-type protoplasts after a $\triangle P=-0.2 \mathrm{M}$ shock, and $79 \%$ for pil1 $\Delta$ protoplasts after a $\Delta \mathrm{P}=-0.1 \mathrm{M}$ shock (Figure $7 \mathrm{~B}$ ). These abrupt changes in the endocytic density were followed by a 2- to 6-minute recovery back to the steady-state endocytic density, and recovery time depended on the magnitude of the hypotonic shock. The temporal variations of the endocytic density after hypotonic shocks mirrored the changes in Fim1p dynamics in endocytic patches in similar conditions (Figure $5 \mathrm{C}, 5 \mathrm{D}, 5 \mathrm{~F}$ and $5 \mathrm{G}$ ). Note that the change in cell volume (Figure 7A \& 7B, insets) could not exclusively account for the observed decrease in the endocytic density as the volume increased faster than the change in endocytic density.

Building on these results in protoplasts, we wondered whether the endocytic density in walled cells also adapts to hypotonic shocks. Indeed, immediately after the 
344 largest shock tested $(\Delta \mathrm{P}=-1.2 \mathrm{M})$, we observed a similar decrease in the endocytic 345 density for both wild-type and pil1 $1 \Delta$ walled cells, $36 \%$ and $46 \%$ respectively (Figure 346 7C). Recovery to steady-state endocytic densities occurred in less than 2 minutes in 347 both wild-type and pil1 $1 \Delta$ walled cells, faster than in protoplasts (Figure 7A, 7B and 348 7C). These results were surprising because we detected virtually no difference in the 349 dynamics of fimbrin recruitment to endocytic sites in both strains (Figure 2E). Our 350 data show that the cell wall limits but does not completely cancel the effect of hypotonic shocks. They also suggest that the regulation of the endocytic density supplements the regulation performed by the eisosomes to reduce membrane tension and enable normal actin machinery dynamics at endocytic sites.

Wild-type and pil1 $\Delta$ walled cells had a very similar adaptation after hypotonic shocks. However, we noticed a difference in the endocytic density at steady state in different sorbitol concentrations. For all concentrations tested ( 0 to $2 \mathrm{M}$ ), wild-type cells maintained roughly the same endocytic density. In contrast, the steady state endocytic density in pil1 1 cells increased with increasing media osmolarity, up to $56 \%$ in $2 \mathrm{M}$ sorbitol (Figure 7D). Our results suggest that eisosomes participate in maintaining a constant density of endocytosis independently of the media osmolarity, not only after an abrupt change in membrane tension, but also when they are at steady state in different osmolarity.

\section{The exocytosis rate increases after a hypotonic shock in protoplasts but not in walled cells}

Reciprocal to the decrease in the number of endocytic events observed after a hypotonic shock, we wondered whether the rate of exocytosis increases in the meantime to provide more surface area to the plasma membrane, as it has been observed in mammalian cells (Gauthier et al., 2009).

To measure the rate of exocytosis in different conditions, we used the cell impermeable styryl dye FM4-64, whose fluorescence dramatically increases when it binds to membranes, to measure the increase of cell surface area due to vesicle fusion (Cochilla et al., 1999; Gachet and Hyams, 2005; Richards et al., 2000). After FM4-64 is introduced to the media, fusion of unstained intracellular vesicles to the plasma membrane results in an increase of total cell fluorescence, because after each fusion event new unstained membrane is exposed to the dye. Note that endocytic events do not increase the total cell fluorescence because they transfer already stained patches of the plasma membrane into the interior of the cell (Figure $8 \mathrm{~A})$. Note also that the increase in total cell fluorescence could also be due to putative transfer of lipids by non-exocytic mechanisms but for simplicity and by lack of further evidence, onwards we will interpret the increase in fluorescence to an increase in the exocytosis rate.

Staining of wild-type fission yeast with $20 \mu \mathrm{M}$ FM4-64 in EMM5S (Figure 8B) showed that after a brief phase of rapid staining of the cell surface, the total cell fluorescence intensity grows linearly for at least 20 minutes, and the slope of the normalized intensity corresponds to the exocytosis rate as a percentage of the plasma membrane surface area per unit of time (see materials and methods) (Gauthier et al., 2009; Smith and Betz, 1996; Vida and Emr, 1995). Using this method, we measured that wild-type walled cells at steady state in EMM5S exocytose $4.6 \%$ of their plasma membrane surface area per minute (Figure $8 \mathrm{~B}$ ). FM4-64 staining did not seem to affect the endocytic and exocytic membrane trafficking of yeast cells, since stained vesicles are successfully released after washing cells with fresh media (Figure 8B). 
We measured the exocytosis rates in the conditions that had the largest effects on endocytosis while keeping most cells alive, i.e. we used protoplasts at steady state in $0.4 \mathrm{M}$ and performing a $\Delta \mathrm{P}=-0.2 \mathrm{M}$ shock for wild-type and $\Delta \mathrm{P}=-0.05$ $\mathrm{M}$ shock for pil1 $\Delta$. At steady state in $0.4 \mathrm{M}$ sorbitol (Figure $8 \mathrm{C}$ and $8 \mathrm{E}$ ), wild-type protoplasts had an exocytosis rate similar to walled cells in EMM5S in $0 \mathrm{M}\left(\mathrm{k}_{0}\right.$ $\left.{ }_{5}=4.4 \pm 0.2 \% \mathrm{~min}^{-1}\right)$. After a $\Delta \mathrm{P}=-0.2 \mathrm{M}$ shock, the exocytosis rate increased by $41 \%$ $\left(\mathrm{k}_{0-5}=6.2 \pm 0.4 \% \mathrm{~min}^{-1}\right)$. At steady state in $0.4 \mathrm{M}$ sorbitol (Figure $8 \mathrm{D}$ and $8 \mathrm{E}$ ), the exocytosis rate of pil1 $\Delta$ protoplasts was higher than for walled cells in $0 \mathrm{M}$ sorbitol $\left(\mathrm{k}_{0-5}=6.2 \pm 0.4 \% \mathrm{~min}^{-1}\right)$. After a $\Delta \mathrm{P}=-0.05 \mathrm{M}$ shock, the exocytosis rate increased modestly $\left(\mathrm{k}_{0-5}=6.8 \pm 0.5 \% \mathrm{~min}^{-1}\right)$. Therefore, in both wild-type and pil1 $\Delta$ protoplasts, an acute hypotonic shock leads to an increased exocytosis rate, which increases surface area and likely reduces membrane tension. The change in exocytosis rate in pil1 1 protoplasts being more modest than in wild-type cells highlights the role of eisosomes in buffering the change in the exocytosis rate in response to change in osmolarity and membrane tension.

We wondered whether these changes in exocytosis rate also happen in walled cells. First, we measured exocytosis rate at steady state in solutions with different molarities and found that the rates were smaller than in protoplasts (Figures 8F, 8G, and $8 \mathrm{H}$ ). The exocytosis rate of wild-type walled cells at steady state in $1.2 \mathrm{M}$ sorbitol $\left(\mathrm{k}_{0-5}=3.1 \pm 0.1 \% \mathrm{~min}^{-1}\right.$, Figure $8 \mathrm{~F}$ and $\left.8 \mathrm{H}\right)$ was $35 \%$ smaller than in $0 \mathrm{M}$ sorbitol $\left(\mathrm{k}_{0-}\right.$ ${ }_{5}=4.8 \pm 0.1 \% \mathrm{~min}^{-1}$, Figure $\left.8 \mathrm{~B}\right)$. In addition, in pil $1 \Delta$ walled cells, the exocytosis rate of walled cells lacking eisosomes in $1.2 \mathrm{M}$ sorbitol was only slightly smaller than wildtype cells in the same conditions $\left(\mathrm{k}_{0-5}=2.6 \pm 0.1 \% \mathrm{~min}^{-1}\right.$, Figure $8 \mathrm{G}$ and $\left.8 \mathrm{H}\right)$. After hypotonic shocks, the change of exocytosis rate in walled cells was very limited (Figure 8F-H). In fact, our strongest hypotonic shock of $\Delta \mathrm{P}=-1.2 \mathrm{M}$ did not significantly increase the exocytosis rate of wild-type or pil1 $1 \Delta$ cells walled cells (Figure $8 \mathrm{H}$ ). These data corroborate our previous finding that the cell wall limits but does not completely cancel the effect of hypotonic shocks in intact cells. In addition, they also demonstrate that eisosomes are involved in the regulation of the exocytosis rate.

\section{Inhibition of exocytosis decreased the survival rate of protoplasts under acute hypotonic shock.}

To further test our hypothesis that reducing the endocytosis rate and increasing the exocytosis rate help regulate membrane tension after a hypotonic shock, we wondered whether blocking endocytosis or exocytosis with drugs would affect the survival rates of cells. We hypothesized that inhibition of endocytosis or exocytosis would have opposite effects on the survival of protoplasts under acute hypotonic shock. Specifically, inhibition of endocytosis would help retain membrane on the surface of protoplasts, thereby reducing the probability of membrane rupture, and, conversely, inhibition of exocytosis would reduce the transfer of membrane from intracellular vesicles to the surface of protoplasts, exasperating the lack of plasma membrane in the face of imminent protoplast expansion. To observe the largest effects, we used pil1 $\Delta$ protoplasts under $\Delta \mathrm{P}=-0.2 \mathrm{M}$ shock, and exposed the cells to either Latrunculin A (LatA) or Brefeldin A (BFA) for 30 minutes before the shocks.

Blocking exocytosis with BFA increases the death rate of protoplasts after hypotonic shocks, confirming our hypothesis (Figure 9 and Figure 9 Supplement 1 ). Blocking actin assembly, and therefore endocytosis, with LatA made the protoplasts more resistant starting 4 minutes after the hypotonic shock, also confirming our 
443 hypothesis. Note that LatA treatment made the protoplasts less resistant to shock in 444 the initial 2 minutes after the hypotonic shock, which seems in contradiction with our 445 hypothesis. However, it is possible that prolonged treatment with LatA had other 446 unidentified effects on protoplasts survival or may indirectly affect the exocytosis rate since LatA affects all actin structures in the cell, including actin cables which are needed for the transport of exocytic vesicles (Lo Presti et al., 2012).

\section{Discussion}

\section{Robustness of CME in fission yeast}

Our data demonstrate that CME is able to proceed in a wide range of osmolarities and membrane tension. Even cells devoid of a cell wall and eisosomes were able to perform endocytosis after an acute change in membrane tension, as long as their plasma membrane was not damaged and cells remained alive. Even in the most extreme conditions tested, i.e. cells devoid of a cell wall and lacking the majority of their eisosomes, the dynamics of fimbrin at endocytic sites was only two times larger than what was observed in wild-type walled cells. These results demonstrate that not only are cells able to adapt their endocytic machinery to acute changes in membrane tension but, they are also able to rapidly regulate their membrane tension.

\section{Mechanisms of tension regulation and homeostasis of the plasma membrane}

Our results demonstrate that the regulation of membrane tension in hypotonic environment is performed via a combination of at least three mechanisms: the mechanical protection by the cell wall, the disassembly of the eisosomes and the temporary shift in the balance between endocytosis and exocytosis (Figure 10). Our data indicate that all three mechanisms are used in parallel, since wild-type walled cells are less sensitive to acute hypotonic shocks than wild-type protoplasts and pil1 $\Delta$ walled cells, and they experience a temporary decrease in their endocytic density for about 2 minutes after the shock. In addition, our data allow us to estimate the relative contribution of each mechanism in the regulation of membrane tension.

The cell wall provides the largest protection during chronic and acute changes in media osmolarity. Wild-type walled cells are virtually insensitive to osmotic changes, and pil1 $\Delta$ walled cells are much less sensitive than pil1 $\Delta$ protoplasts. Removal of the cell wall dramatically affects actin dynamics at endocytic sites and eisosome assembly at the plasma membrane (Figure 4B, 4C, 4F and 4G), and greatly increased the effect of hypotonic shock on exocytosis (Figure $8 \mathrm{C}-\mathrm{F}$ ). It is surprising that endocytosis in protoplasts still proceeds in media with osmolarity as low as $0.25 \mathrm{M}$, where a large fraction of eisosomes is disassembled. In fact, the actin endocytic machinery can overcome membrane tensions high enough to rupture the plasma membrane since we did not see stalled actin patches, or actin comet tails, in any of our experiments. Our results contrast with recent data in S. cerevisiae (Riggi et al., 2019) where endocytosis is blocked and actin comet tails are formed within 2 minutes of a hypotonic shock. These differences may highlight species specificities.

Our results add to a growing body of evidence that eisosomes play a critical role in the regulation of membrane tension and membrane integrity through dynamic remodeling and scaffolding of the plasma membrane (Kabeche et al., 2015; Moseley, 2018). Endocytosis in wild-type walled cells are not sensitive to chronic or acute 490 hypotonic changes, whereas pil14 walled cells are (Figure 2 and Figure 3). 
491 Conversely, exocytosis seems to respond more strongly to acute hypotonic shock in 492 wild-type walled cells than in pil1 1 walled cells (Figure 8E and 8F). The protective 493 role of eisosomes is even more striking in protoplasts under acute hypotonic shocks. 494 Wild-type protoplasts whose plasma membrane is covered with eisosomes are 495 largely insensitive to increases in membrane tension whereas protoplasts with little to 496 no eisosomes are extremely sensitive to increases in membrane tension and their 497 plasma membrane is easily damaged (Figure 6A-C). Eisosomes retain this protective 498 function even in walled cells, which becomes evident when cells are put under 499 repeated osmolarity shocks (Figure 6D-F). Our micropipette aspiration experiments 500 also demonstrate that eisosomes are critical to keep membrane tension low during an acute hypotonic shock. Therefore, our data indicate that membrane tension is decreased via the disassembly of eisosomes, through release of excess membrane surface area. Assuming eisosomes are hemi-cylinders with diameter $\sim 50 \mathrm{~nm}$ and cells contain $1.6 \mu \mathrm{m}$ of eisosomes per $\mu \mathrm{m}^{2}$ of plasma membrane on average, total eisosome disassembly could release about $5 \%$ of the total surface area of the plasma membrane over $\sim 3$ minutes after a hypotonic shock (Kabeche et al., 2015), although a mild shock of $\Delta \mathrm{P}=-0.2 \mathrm{M}$ disassembled close to $\sim 50 \%$ eisosomes over 5 minutes, or about $2.5 \%$ of the surface area of the plasma membrane (Figure $4 \mathrm{H}$ and 4I). Recent single-molecule imaging in our lab demonstrated that at steady state Pil1p undergoes rapid exchange at the eisosome ends (Lacy et al., 2017), potentially providing a convenient route for rapid disassembly of the BAR domain-mediated scaffold, analogous to filament depolymerization, in combination with eisosome breaking. Disassembled eisosome components have altered phosphorylation level or sub-cellular localization, which potentially relays the signaling from eisosome integrity to endocytosis and/or exocytosis (Riggi et al., 2018; Walther et al., 2007), possibly via TORC2 (Riggi et al., 2019).

Our study highlights a third mechanism to reduce membrane tension by increasing the surface area of the plasma membrane via a temporary reduction in the endocytosis rate and an increase in the exocytosis rate. Using our data, we estimate that cells endocytose about $2 \%$ of their surface area per minute through clathrin mediated endocytosis, confirming our previous measurements (Berro and Pollard, $2014 a, 2014 b)$. During acute hypotonic shock, a reduction of the endocytosis rate plus an increase in the exocytosis rate for a few minutes would allow for a net addition of surface area to the plasma membrane. For example, in pil1 $\Delta$ protoplasts initially at steady state in $0.4 \mathrm{M}$ sorbitol the endocytosis rate is reduced by $\sim 25 \%$ for $\sim 10$ minutes after an acute hypotonic shock of $\Delta \mathrm{P}=-0.05 \mathrm{M}$, while the exocytosis rate increased by $\sim 10 \%$. The net surface area added over that period by reduction in endocytosis and increase in exocytosis corresponds to a $5 \%+6 \%=11 \%$ increase in the protoplast surface area, close to the $\sim 12 \%$ surface area increase we measured. These results confirm and quantify previous reports of control of surface tension by increasing the surface area via a modulation of endocytosis and exocytosis rates in other eukaryotes (Apodaca, 2002; Homann, 1998; Morris and Homann, 2001). These estimates demonstrate that modulating the endocytosis and exocytosis rates is an efficient way to increase the surface area of the plasma membrane by large amounts, but this process is relatively slow compared to eisosome disassembly. The slowness of this process might explain why pil1 $\Delta$ and pre-stretched wild-type protoplasts that have about half the normal amount of eisosomes on their surface do not survive even relatively small hypotonic shocks, being unable to provide enough membrane in a short amount of time to reduce the tension of their plasma membrane. 
541 Molecular mechanisms driving the adaptation of the actin endocytic machinery 542 and the rate of endocytosis under various membrane tensions

Under conditions where membrane tension and turgor pressure were significantly increased, we observed that the endocytic actin machinery took longer and assembled a larger number of fimbrin molecules to successfully produce endocytic vesicles. This effect increased with increasing membrane tension, up to tensions high enough to rupture the cell plasma membrane. This result strongly supports the idea that the actin machinery provides the force that counteracts membrane tension and turgor pressure and deforms the plasma membrane into an endocytic pit.

The precise molecular mechanism that regulates this enhanced assembly remains to be uncovered. Our data suggest that actin dynamics is controlled via a mechanical or geometrical regulation, where actin assembles until the plasma membrane is deformed and pinched off. An alternative, and non-mutually exclusive, hypothesis is that the activity and/or recruitment of proteins upstream of the actin nucleators may be enhanced by increased membrane tension. A third hypothesis is that the decrease in the number of endocytic events after an increase in membrane tension leads to an increase in the concentration of endocytic proteins in the cytoplasm, which can then enhance the reactions performed at the endocytic sites. Sirotkin et al (Sirotkin et al., 2010) measured that $65 \%$ to $85 \%$ of the total cellular content of key proteins involved in the endocytic actin machinery are localized to endocytic sites at any time. A $20 \%$ decrease in the number of endocytic sites would increase their cytoplasmic abundance by roughly $40 \%$ to $80 \%$. This percentage is larger than the volume changes we measured, resulting in a net increase in the cytoplasmic concentration of these proteins, which would allow larger amount of protein to assemble at the endocytic sites.

Conversely, the decreased endocytosis rate could be attributed to the larger number of endocytic proteins assembled at each endocytic sites, which would decrease their cytoplasmic concentration. Indeed, Burke et al. (Burke et al., 2014) showed that modulating actin concentration modulates the number of endocytic sites in the same direction. However, it is more likely that one or several early endocytic proteins are sensitive to membrane tension, and either fail to bind the plasma membrane or prevent the triggering of actin assembly when membrane tension is high. This idea would be consistent with results from mammalian cells demonstrating that the proportion of stalled clathrin-coated pits increases when membrane tension increases (Ferguson et al., 2017). In addition, several endocytic proteins that arrive before or concomitantly with the activators of the actin machinery contain BAR domains (such as Syp1p, Bzz1p and Cdc15p), and other members of this domain family (which also includes Pil1p) have been shown to bind membranes in a tensionsensitive manner. Further quantitative study of early endocytic proteins will help uncover the validity and relative contributions of each one of these hypotheses.

We expect our results to be relevant to the study of CME and membrane tension regulation in higher order eukaryotes. Indeed, the molecular machineries for endocytosis, exocytosis and osmotic response are highly conserved between fission yeast and other eukaryotes. In addition, regulation of membrane tension and CME are particularly critical during cell polarization (Mostov et al., 2000), during neuron development and shape changes (Urbina et al., 2018) and at synapses where large pools of membranes are added and retrieved on a very fast time scale (NicholsonFish et al., 2016; Watanabe and Boucrot, 2017). 
592 Yeast strains and media

593

594

595

596

597

598

599

600

601

602

603

604

605

606

607

608

609

610

611

612

613

614

615

616

617

618

619

The S. pombe strains used in this study are listed in Supplemental Table S1. Yeast cells were grown in YE5S (Yeast Extract supplemented with $0.225 \mathrm{~g} / \mathrm{L}$ of uracil, lysine, histidine, adenine and leucine), which was supplemented with 0 to 1.2 $\mathrm{M}$ D-Sorbitol, at $32^{\circ} \mathrm{C}$ in exponential phase for about 18 hours. Cells were washed twice and resuspended in filtered EMM5S (Edinburgh Minimum media supplemented with $0.225 \mathrm{~g} / \mathrm{L}$ of uracil, lysine, histidine, adenine and leucine), which was supplemented with the same concentration of D-Sorbitol, at least 10 minutes before imaging so they can adapt and reach steady state.

\section{Protoplasts preparation}

S. pombe cells were grown in YE5S at $32^{\circ} \mathrm{C}$ in exponential phase for about 18 hours. $10 \mathrm{~mL}$ of cells were harvested and washed two times with SCS buffer $(20 \mathrm{mM}$ citrate buffer, $1 \mathrm{M}$ D-Sorbitol, $\mathrm{pH}=5.8$ ), and resuspended in SCS supplemented with $0.1 \mathrm{~g} / \mathrm{mL}$ Lallzyme (Lallemand, Montreal, Canada) (Flor-Parra et al., 2014). Cells were incubated with gentle shaking for 10 minutes at $37^{\circ} \mathrm{C}$ in the dark except for experiments in Figure 9, where cells were digested at room temperature with gentle shaking for 30 minutes in the presence of inhibitors. The resulting protoplasts were gently washed twice in EMM5S with 0.25 to $1.2 \mathrm{M}$ D-Sorbitol, spun down for 3 minutes at $0.4 \mathrm{rcf}$ between washes, and resuspended in EMM5S buffer supplemented with 0.25 to $1.2 \mathrm{M}$ D-Sorbitol at least 10 minutes before imaging so they can adapt and reach steady state.

\section{Microscopy}

Microscopy was performed using a spinning disk confocal microscope, built on a TiE inverted microscope (Nikon, Tokyo, Japan), equipped with a CSU-W1 spinning head (Yokogawa Electric Corporation, Tokyo, Japan), a 100X/1.45NA Phase objective, an iXon Ultra888 EMCCD camera (Andor, Belfast, UK), and the NISElements software v. 4.30.02 (Nikon, Tokyo, Japan) on. The full system was switched on at least 45 minutes prior to any experiments to stabilize the laser power and the room temperature. Cells were loaded into commercially available microfluidics chambers for haploid yeast cells (Y04C-02-5PK, Millipore-Sigma, SaintLouis, USA) for the CellASIC ONIX2 microfluidics system (Millipore-Sigma, SaintLouis, USA). Each field of view was imaged for 60 seconds, and each second a stack of $6 \mathrm{z}$-slices separated by $0.5 \mu \mathrm{m}$ was imaged. The microscope was focused such that the part of the cell closest to the coverslip was captured.

\section{Acute hypotonic shocks}

Walled cells or protoplasts were first imaged in their steady state media (EMM5S supplemented with 0 to $1.2 \mathrm{M}$ D-Sorbitol). The steady state media was exchanged with media supplemented with a lower D-Sorbitol concentration (the concentration difference is noted $\Delta \mathrm{P})$, with inlet pressure of $5 \mathrm{psi}$. This hypotonic shock media was labelled with $6.7 \mu \mathrm{g} / \mathrm{mL}$ of sulforhodamine B (MP Biomedicals LLC, Santa Ana, USA), a red cell-impermeable dye that allowed us to a) monitor the full exchange of the solution in the microfluidic chamber prior to image acquisition, and b) monitor the plasma membrane integrity of the cells after the shock. In each

638 condition, the first movie was started when the sulforhodamine B dye was visible in 
639 the field of view. For clarity, this time point is labelled $t=0 \mathrm{~min}$ in all our figures, but 640 note that we estimate it may vary by up to 30 seconds between movies and 641 conditions. We imaged cells by taking one stack of 6 Z-slices per second for 60 642 seconds. After the end of each movie, we rapidly changed field of view and restarted 643 acquisition one minute after the end of the previous movie, so that movies started 644 every 2 minutes after the acute hypotonic shock. Tracks from cells that contained red fluorescence from the sulforhodamine B dye were excluded from the analysis, because this indicated that cell membrane had been damaged.

\section{Inhibition of endocytosis and exocytosis during acute hypotonic shock}

Endocytosis or exocytosis was inhibited by including respectively $25 \mathrm{uM}$ Latrunculin A (Millipore, MA, USA) or 2mM Brefeldin A (Santa Cruz Biotechnology Inc., TX, USA) in the solution used to prepare the protoplasts and and to perform the hypotonic shocks. Hypotonic shock solution also included $20 \mu \mathrm{M}$ FM4-64 (Biotium, Fremont, CA, USA) to stain dead protoplasts (Vida and Gerhardt, 1999) (Figure 9 Supplement 1), and inlet pressure was set at 4 psi.

\section{Measurement of the temporal evolution of the number of proteins and speed}

Movies were processed and analyzed using an updated version of the PatchTrackingTools toolset for the Fiji (Schindelin et al., 2012) distribution of ImageJ (Berro and Pollard, 2014a; Schneider et al., 2012). This new version includes automatic patch tracking capabilities based on the Trackmate library (Tinevez et al., 2017), and is available on the Berro lab website: http://campuspress.yale.edu/berrolab/

publications/software/. Prior to any quantitative measurements, we corrected our movies for uneven illumination and camera noise. The uneven illumination was measured by imaging a solution of Alexa 488 dye and the camera noise was measured by imaging a field of view with $0 \%$ laser power. We tracked Fim1-mEGFP spots with a circular 7-pixel diameter region of interest (ROI), and measured the temporal evolution of the fluorescence intensities and the position of the centers of mass. The spot intensity was corrected for cytoplasmic background using a 9-pixel median filter, and was then corrected for photobleaching. The photobleaching rate was estimated by fitting a single exponential to the temporal evolution of the intensity of cytoplasmic ROls void of any identifiable spots of fluorescence (Berro and Pollard, 2014a). Only tracks longer than $5 \mathrm{~s}$ and displaying an increase followed by a decrease in intensity were kept for the analysis. Individual tracks were aligned and averaged with the temporal super-resolution algorithm from (Berro and Pollard, 2014a), and post-processed using custom scripts in Matlab R2016a (Mathworks). In brief, this method realigns temporal signals that have low temporal resolution and where no absolute time reference is available to align them relatively to each other. It iteratively finds the temporal offset which has a higher precision than the measured signal and minimizes the mean square difference between each measured signal and a reference signal. For the first round of alignments, the reference signal is one of the measurements. After each realignment round, a new reference is calculated as the mean of all the realigned signals, which is an estimator of the true underlying signal.

To control and calibrate the intensity of our measurements, we imaged wildtype walled cell expressing Fim1p-mEGP each imaging day. Intensities were converted into number of molecules with a calibration factor such that the peak 688 intensity of our control strain corresponded to 830 molecules (Berro and Pollard, 
689

690

691

692

693

694

695

696

697

698

699

700

701

702

703

704

705

706

707

708

709

710

711

712

713

714

715

716

717

718

719

720

721

722

723

724

725

726

727

728

729

730

731

732

733

734

735

736

2014a).

In all figures presenting the temporal evolution of the number of molecules or the speed, time $0 \mathrm{~s}$ corresponds to the time point when the number of molecules is maximum (also called the peak number). Satistical tests between conditions were performed at time $0 \mathrm{~s}$ with a one-way ANOVA test using the number of tracks collected to build the figure. To avoid extrapolating the data, we compared the relative duration of assembly and disassembly between conditions using the time at which the average number of molecules reach half the peak number.

\section{Measurement of the density of CME events}

We used the $S$. Pombe profiling tools for ImageJ (Berro and Pollard, 2014a) to measure the number of endocytic events at a given time in each cell. In brief, on a sum-projected z-stack, we manually outlined individual cells, and, for each position along the long axis of a cell, we measured the sum of fluorescence orthogonal to the long axis. We corrected the intensity profile in each cell for its cytoplasmic intensity and media fluorescence outside the cell. We estimated the number of patches in each cell by dividing the corrected fluorescence signal with the temporal average of the fluorescence intensity of one endocytic event. We calculated the linear density of endocytic events as the ratio between the number of endocytic events in a cell and its length.

\section{Measurement of the exocytosis rate with FM4-64 staining}

The exocytosis rate was measured by combining the acute hypotonic shock with FM4-64 staining, in a similar approach as has been reported (Gauthier et al., 2009; Smith and Betz, 1996; Vida and Emr, 1995). The cell impermeable dye FM464 (Biotium, Fremont, CA, USA) was diluted to a final concentration of $20 \mu \mathrm{M}$ in any of the media used. When cells are exposed to FM4-64, the dye rapidly stains the outer leaflet of the plasma membrane. Upon endocytosis, the dye is trafficked inside the cell without change in fluorescence. The total cell fluorescence intensity was measured after segmenting the cells by thresholding the fluorescence signal above background levels. The fluorescence intensity was normalized to the intensity reached at the end of the fast increase $\sim 1$ min after the dye was flowed in, which corresponds to the intensity of total surface area of the plasma membrane (Figure $8 \mathrm{~B})$. After this fast phase ( $<20$ seconds), the fluorescence signal increased more slowly every time unstained membrane was exposed to the cell surface by exocytosis. At short time scale ( 5 to 20 min depending on the exocytosis rate), recycling of stained membrane is negligible and one can assume that all exocytosed membrane is virtually unstained. Since the intensity at the beginning of the slow phase was normalized to 1 , the slope of the linear increase of fluorescence is equal to the amount of membrane exocytosed per minute, expressed as a fraction of the surface area of the plasma membrane. For all measurements, images were taken at $5 \mathrm{~s}$ interval at the midline of cells with the help of Perfect Focusing System (Nikon, Tokyo, Japan), with minimal laser excitation in order to reduce toxicity and photobleaching to negligible values. Curve fitting and slope calculation was performed in GraphPad Prism (GraphPad Software, La Jolla, CA, USA).

\section{Measurement of eisosomes' density on the plasma membrane}

We imaged full cells expressing Pil1p-mEGFP by taking stacks of $0.5 \mu \mathrm{m}$ spaced Z-slices. We corrected these Z-stacks for uneven illumination and manually outlined individual cells to determine the surface area of each cell. To determine the 
737 total amount of eisosome-bound Pil1p-mEGFP we subtracted the cytosolic intensity

738 of Pil1-mEGFP using a pre-determined threshold and summed all the Z-slices. We

739 measured the mean membrane intensity of each cell on the thresholded sum-

740 projection image. The eisosome density was determined by dividing this mean

741 intensity by the surface area of each protoplast.

742

743

To quantify the relative changes in area fraction of eisosomes after acute hypotonic shock, wild-type protoplasts expressing Pil1p-mEGFP were loaded into ONIX2 microfluidics system (Millipore-Sigma, Saint-Louis, USA), and time lapse fluorescent images were taken at a single Z-slice at the top of protoplasts during media change. After background correction, the total area fraction of eisosomes at the beginning of hypotonic shock was set to 1.0 for normalization, and the normalized values of area fraction were fit to a single exponential decay curve in GraphPad Prism (GraphPad Software, La Jolla, CA, USA).

\section{Measurement of membrane tension}

Protoplasts were loaded in a custom-built chamber which was passivated with $0.2 \mathrm{mg} / \mathrm{mL}$ $\beta$-casein (Millipore-Sigma, Saint-Louis, USA) for 30 minutes and preequilibrated with EMM5S supplemented with $0.8 \mathrm{M}$ D-Sorbitol. A glass micropipette (\#1B100-4, World Precision Instruments, Sarasota, USA) was forged to a diameter smaller than the average protoplast radius $(\sim 2.5 \mu \mathrm{m})$, and was connected to a water reservoir of adjustable height to apply a defined aspiration pressure. Before and after each experiment the height of the water reservoir was adjusted to set the aspiration pressure to 0 . Cells were imaged with a bright field IX-71 inverted microscope (Olympus, Tokyo, Japan) equipped with a 60X/1.4NA objective, and images were recorded every second. Aspiration pressure was gradually increased every $30 \mathrm{~s}$ and the membrane tension $\sigma$ was calculated as $\sigma=\Delta P . R_{p} /\left[2\left(1-R_{p} / R_{c}\right)\right]$, where $R_{p}$ and $R_{c}$ are respectively the micropipette and the cell radius, $\Delta P$ is the aspiration pressure for which the length of the tongue $l$ of the protoplast in the micropipette is equal to $R_{p}$ (Evans and Yeung, 1989). To limit the effects of the adaptation of cells' membrane tension, all measurements were performed within the first five minutes after the hypotonic shock, which greatly limited the throughput of our assay (1 measurement per sample), compared to the measurements at steady state (around 6 measurements per sample).

We thank Yale West Campus Imaging core for providing access to the spinning disc confocal microscope, members of the Berro lab for insightful discussions and $\mathrm{R}$. Fernandez for providing mutant yeast strains. We thank Ramesh Ramji and Kathryn Miller-Jensen for initial help with the microfluidics part of this project. We gratefully thank Millipore Sigma for lending us a CellASIC unit and Erdem Karatekin for access to his micropipette aspiration setup. We also thank Samantha Dundon, Mike Lacy and Matt Akamatsu for their comments on our manuscript. This research was supported in part by National Institutes of Health/National Institute of General Medical Sciences Grant R01GM115636 and by seed funding from the American Cancer Society Institutional Research Grant \#IRG 58-012-58. 
bioRxiv preprint doi: https://doi.org/10.1101/342030; this version posted January 27, 2021. The copyright holder for this preprint (which was not certified by peer review) is the author/funder, who has granted bioRxiv a license to display the preprint in perpetuity. It is made available under aCC-BY-NC-ND 4.0 International license.

783 
Aghamohammadzadeh S, Ayscough KR. 2009. Differential requirements for actin during yeast and mammalian endocytosis. Nature cell biology 11:1039-1042. doi:10.1038/ncb1918

Aghamohammadzadeh S, Smaczynska-de Rooij II, Ayscough KR. 2014. An Abp1dependent route of endocytosis functions when the classical endocytic pathway in yeast is inhibited. PLOS ONE 9. doi:10.1371/journal.pone.0103311

Apodaca G. 2002. Modulation of membrane traffic by mechanical stimuli. American Journal of Physiology-Renal Physiology 282:F179-F190. doi:10.1152/ajprenal.2002.282.2.F179

Arasada R, Pollard TD. 2011. Distinct Roles for F-BAR Proteins Cdc15p and Bzz1p in Actin Polymerization at Sites of Endocytosis in Fission Yeast. Current Biology 21:1450-1459. doi:10.1016/j.cub.2011.07.046

Arasada R, Sayyad WAWA, Berro J, Pollard TDTD. 2018. High-speed superresolution imaging of the proteins in fission yeast clathrin-mediated endocytic actin patches. Molecular Biology of the Cell 29:295-303. doi:10.1091/mbc.E17-06-0415

Atilgan E, Magidson V, Khodjakov A, Chang F. 2015. Morphogenesis of the Fission Yeast Cell through Cell Wall Expansion. Current biology $\square:$ CB 25:2150-7. doi:10.1016/j.cub.2015.06.059

Basu R, Munteanu EL, Chang F. 2013. Role of turgor pressure in endocytosis in fission yeast. Molecular biology of the cell 25:679-87. doi:10.1091/mbc.E1310-0618

Berro J, Lacy MM. 2018. Quantitative Biology of Endocytosis, Colloquium Series on Quantitative Cell Biology (Marshall WF, ed). San Rafael (CA): Morgan \& Claypool.

Berro J, Pollard TD. 2014a. Local and global analysis of endocytic patch dynamics in fission yeast using a new "temporal superresolution" realignment method. MBoC 25:3501-3514. doi:10.1091/mbc.e13-01-0004

Berro J, Pollard TD. 2014b. Synergies between Aip1p and capping protein subunits (Acp1p and Acp2p) in clathrin-mediated endocytosis and cell polarization in fission yeast. MBoC 25:3515-3527. doi:10.1091/mbc.e13-01-0005

Berro J, Sirotkin V, Pollard TD. 2010. Mathematical Modeling of Endocytic Actin Patch Kinetics in Fission Yeast: Disassembly Requires Release of Actin Filament Fragments. MBoC 21:2905-2915. doi:10.1091/mbc.e10-06-0494

Boulant S, Kural C, Zeeh J-C, Ubelmann F, Kirchhausen T. 2011. Actin dynamics counteract membrane tension during clathrin-mediated endocytosis. Nature cell biology 13:1124-1131. doi:10.1038/ncb2307

Burke TA, Christensen JR, Barone E, Suarez C, Sirotkin V, Kovar DR. 2014. Homeostatic actin cytoskeleton networks are regulated by assembly factor competition for monomers. Current Biology 24:579-585. doi:10.1016/j.cub.2014.01.072

Carlsson AE, Bayly P V. 2014. Force generation by endocytic actin patches in budding yeast. Biophysical Journal 106:1596-1606. doi:10.1016/j.bpj.2014.02.035

Chen Q, Pollard TD. 2013. Actin Filament Severing by Cofilin Dismantles Actin Patches and Produces Mother Filaments for New Patches. Current Biology 23:1154-1162. doi:10.1016/J.CUB.2013.05.005 
832 Cheng JPX, Mendoza-Topaz C, Howard G, Chadwick J, Shvets E, Cowburn AS,

833

834

835

836

837

838

839

840

841

842

843

844

845

846

847

848

849

850

851

852

853

854

855

856

857

858

859

860

861

862

863

864

865

866

867

868

869

870

871

872

873

874

875

876

877

878

879

Dunmore BJ, Crosby A, Morrell NW, Nichols BJ. 2015. Caveolae protect

endothelial cells from membrane rupture during increased cardiac output. The Journal of Cell Biology 211:53-61. doi:10.1083/jcb.201504042

Cochilla AJ, Angleson JK, Betz WJ. 1999. MONITORING SECRETORY MEMBRANE WITH FM1-43 FLUORESCENCE. Annual Review of Neuroscience 22:1-10. doi:10.1146/annurev.neuro.22.1.1

Courtemanche N, Pollard TD, Chen Q. 2016. Avoiding artefacts when counting polymerized actin in live cells with LifeAct fused to fluorescent proteins. Nature Cell Biology 18:676-683. doi:10.1038/ncb3351

Davì V, Tanimoto H, Ershov D, Haupt A, De Belly H, Le Borgne R, Couturier $E$, Boudaoud A, Minc N. 2018. Mechanosensation Dynamically Coordinates Polar Growth and Cell Wall Assembly to Promote Cell Survival. Developmental cell 45:170-182.e7. doi:10.1016/j.devcel.2018.03.022

Dmitrieff S, Nédélec F. 2015. Membrane Mechanics of Endocytosis in Cells with Turgor. PLoS Computational Biology 11. doi:10.1371/journal.pcbi.1004538

Evans E, Yeung a. 1989. Apparent viscosity and cortical tension of blood granulocytes determined by micropipet aspiration. Biophysical journal 56:151160. doi:10.1016/S0006-3495(89)82660-8

Ferguson JP, Huber SD, Willy NM, Aygün E, Goker S, Atabey T, Kural C. 2017. Mechanoregulation of clathrin-mediated endocytosis. Journal of Cell Science 130:3631-3636. doi:10.1242/jcs.205930

Ferguson S, Raimondi A, Paradise S, Shen H, Mesaki K, Ferguson A, Destaing O, Ko G, Takasaki J, Cremona O, O' Toole E, De Camilli P. 2009. Coordinated Actions of Actin and BAR Proteins Upstream of Dynamin at Endocytic Clathrin-Coated Pits. Developmental Cell 17:811-822. doi:10.1016/j.devcel.2009.11.005

Flor-Parra I, Zhurinsky J, Bernal M, Gallardo P, Daga RR. 2014. A Lallzyme MMXbased rapid method for fission yeast protoplast preparation. Yeast 31:61-66. doi:10.1002/yea.2994

Gachet Y, Hyams JS. 2005. Endocytosis in fission yeast is spatially associated with the actin cytoskeleton during polarised cell growth and cytokinesis. Journal of Cell Science 118:4231-4242. doi:10.1242/jcs.02530

Gauthier NC, Rossier OM, Mathur A, Hone JC, Sheetz MP. 2009. Plasma Membrane Area Increases with Spread Area by Exocytosis of a GPI-anchored Protein Compartment. Molecular Biology of the Cell 20:3261-3272. doi:10.1091/mbc.e09-01-0071

Hassinger JE, Oster G, Drubin DG, Rangamani P. 2017. Design principles for robust vesiculation in clathrin-mediated endocytosis. Proceedings of the National Academy of Sciences 114:E1118-E1127. doi:10.1073/pnas.1617705114

Hohmann S. 2015. An integrated view on a eukaryotic osmoregulation system. Current Genetics 61:373-382. doi:10.1007/s00294-015-0475-0

Hohmann S. 2002. Osmotic Stress Signaling and Osmoadaptation in Yeasts Osmotic. Microbiology and Molecular Biology Reviews 66:300-372. doi:10.1128/MMBR.66.2.300

Homann U. 1998. Fusion and fission of plasma-membrane material accommodates for osmotically induced changes in the surface area of guard-cell protoplasts. Planta 206:329-333. doi:10.1007/s004250050408 
880 Kabeche R, Baldissard S, Hammond J, Howard L, Moseley JB. 2011. The filament-

881

882

883

884

885

886

887

888

889

890

891

892

893

894

895

896

897

898

899

900

901

902

903

904

905

906

907

908

909

910

911

912

913

914

915

916

917

918

919

920

921

922

923

924

925

926

927

928

929 forming protein Pil1 assembles linear eisosomes in fission yeast. Molecular Biology of the Cell 22:4059-4067. doi:10.1091/mbc.E11-07-0605

Kabeche R, Howard L, Moseley JB. 2015. Eisosomes provide membrane reservoirs for rapid expansion of the yeast plasma membrane. Journal of Cell Science 128:4057-4062. doi:10.1242/jcs.176867

Lacy MM, Baddeley D, Berro J, Lidke D. 2017. Single-molecule imaging of the BARdomain protein Pil1p reveals filament-end dynamics. MBoC 28:2251-2259. doi:10.1091/mbc.e17-04-0238

Lacy MM, Ma R, Ravindra NG, Berro J. 2018. Molecular mechanisms of force production in clathrin-mediated endocytosis. FEBS Letters. doi:10.1002/18733468.13192

Lo HP, Hall TE, Parton RG. 2016. Mechanoprotection by skeletal muscle caveolae. BioArchitecture 0992:00-00. doi:10.1080/19490992.2015.1131891

Lo Presti L, Chang F, Martin SG. 2012. Myosin Vs organize actin cables in fission yeast. Molecular Biology of the Cell. doi:10.1091/mbc.E12-07-0499

Ma R, Berro J. 2020. Endocytosis against high turgor pressure is made easier by partial protein coating and a freely rotating base. bioRxiv 558890 . doi:10.1101/558890

Minc N, Boudaoud A, Chang F. 2009. Mechanical forces of fission yeast growth. Current biology $\square: C B$ 19:1096-1101. doi:10.1016/j.cub.2009.05.031

Morris CE, Homann U. 2001. Cell Surface Area Regulation and Membrane Tension. The Journal of Membrane Biology 179:79-102. doi:10.1007/s002320010040

Moseley JB. 2018. Eisosomes. Current Biology 28:R376-R378. doi:10.1016/J.CUB.2017.11.073

Mostov KE, Verges M, Altschuler Y. 2000. Membrane traffic in polarized epithelial cells. Current Opinion in Cell Biology 12:483-490. doi:10.1016/S09550674(00)00120-4

Nicholson-Fish JC, Smillie KJ, Cousin MA. 2016. Monitoring activity-dependent bulk endocytosis with the genetically-encoded reporter VAMP4-pHluorin. Journal of Neuroscience Methods 266:1-10. doi:10.1016/j.jneumeth.2016.03.011

Olivera-Couto A, Grana M, Harispe L, Aguilar PS. 2011. The eisosome core is composed of BAR domain proteins. Molecular Biology of the Cell 22:23602372. doi:10.1091/mbc.E10-12-1021

Palmer SE, Smaczynska-de Rooij II, Marklew CJ, Allwood EG, Mishra R, Johnson S, Goldberg MW, Ayscough KR. 2015. A dynamin-actin interaction is required for vesicle scission during endocytosis in yeast. Current Biology 25:868-878. doi:10.1016/j.cub.2015.01.061

Parton RG, Pozo MA del, Vassilopoulos S, Nabi IR, Lay SL, Lundmark R, Kenworthy AK, Camus A, Blouin CM, Sessa WC, Lamaze C. 2019. Caveolae: The FAQs. Traffic n/a. doi:10.1111/tra.12689

Richards DA, Guatimosim C, Betz WJ. 2000. Two Endocytic Recycling Routes Selectively Fill Two Vesicle Pools in Frog Motor Nerve Terminals. Neuron 27:551-559. doi:10.1016/S0896-6273(00)00065-9

Riggi M, Bourgoint C, Macchione M, Matile S, Loewith R, Roux A. 2019. TORC2 controls endocytosis through plasma membrane tension. The Journal of Cell Biology. doi:10.1083/jcb.201901096

Riggi M, Niewola-Staszkowska K, Chiaruttini N, Colom A, Kusmider B, Mercier V, Soleimanpour S, Stahl M, Matile S, Roux A, Loewith R. 2018. Decrease in plasma membrane tension triggers Ptdlns $(4,5) \mathrm{P} 2$ phase separation to 
930

931

932

933

934

935

936

937

938

939

940

941

942

943

944

945

946

947

948

949

950

951

952

953

954

955

956

957

958

959

960

961

962

963

964

965

966

967

968

969

970

971

972

973

974

975

976

977

978

979

inactivate TORC2. Nature Cell Biology 20:1043-1051. doi:10.1038/s41556018-0150-z

Schaber J, Adrover MÀ, Eriksson E, Pelet S, Petelenz-Kurdziel E, Klein D, Posas F, Goksör M, Peter M, Hohmann S, Klipp E. 2010. Biophysical properties of Saccharomyces cerevisiae and their relationship with HOG pathway activation. European Biophysics Journal 39:1547-1556. doi:10.1007/s00249010-0612-0

Schindelin J, Arganda-Carreras I, Frise E, Kaynig V, Longair M, Pietzsch T, Preibisch S, Rueden C, Saalfeld S, Schmid B, Tinevez JY, White DJ, Hartenstein V, Eliceiri K, Tomancak P, Cardona A. 2012. Fiji: An open-source platform for biological-image analysis. Nature Methods. doi:10.1038/nmeth.2019

Schneider CA, Rasband WS, Eliceiri KW. 2012. NIH Image to ImageJ: 25 years of image analysis. Nature Methods 9:671-675. doi:10.1038/nmeth.2089

Sens P, Turner MS. 2006. Budded membrane microdomains as tension regulators. Physical Review E - Statistical, Nonlinear, and Soft Matter Physics 73:1-4. doi:10.1103/PhysRevE.73.031918

Sinha B, Köster D, Ruez R, Gonnord P, Bastiani M, Abankwa D, Stan R V., ButlerBrowne G, Vedie B, Johannes L, Morone N, Parton RG, Raposo G, Sens P, Lamaze C, Nassoy P. 2011. Cells respond to mechanical stress by rapid disassembly of caveolae. Cell 144:402-413. doi:10.1016/j.cell.2010.12.031

Sirotkin V, Berro J, Macmillan K, Zhao L, Pollard TD. 2010. Quantitative analysis of the mechanism of endocytic actin patch assembly and disassembly in fission yeast. Molecular biology of the cell 21:2894-904. doi:10.1091/mbc.E10-020157

Skau CT, Courson DS, Bestul AJ, Winkelman JD, Rock RS, Sirotkin V, Kovar DR. 2011. Actin filament bundling by fimbrin is important for endocytosis, cytokinesis, and polarization in fission yeast. The Journal of biological chemistry 286:26964-77. doi:10.1074/jbc.M111.239004

Smith CB, Betz WJ. 1996. Simultaneous independent measurement of endocytosis and exocytosis. Nature 380:531-534. doi:10.1038/380531a0

Stachowiak MR, Laplante C, Chin HF, Guirao B, Karatekin E, Pollard TD, O'Shaughnessy B. 2014. Mechanism of cytokinetic contractile ring constriction in fission yeast. Developmental cell 29:547-61. doi:10.1016/j.devcel.2014.04.021

Suarez C, Carroll RT, Burke TA, Christensen JR, Bestul AJ, Sees JA, James ML, Sirotkin V, Kovar DR. 2015. Profilin Regulates F-Actin Network Homeostasis by Favoring Formin over Arp2/3 Complex. Developmental Cell 32:43-53. doi:10.1016/J.DEVCEL.2014.10.027

Suescún-Bolívar LP, Thomé PE. 2015. Osmosensing and osmoregulation in unicellular eukaryotes. World Journal of Microbiology and Biotechnology 31:435-443. doi:10.1007/s11274-015-1811-8

Tinevez JY, Perry N, Schindelin J, Hoopes GM, Reynolds GD, Laplantine E, Bednarek SY, Shorte SL, Eliceiri KW. 2017. TrackMate: An open and extensible platform for single-particle tracking. Methods 115:80-90. doi:10.1016/j.ymeth.2016.09.016

Urbina FL, Gomez SM, Gupton SL. 2018. Spatiotemporal organization of exocytosis emerges during neuronal shape change. Journal of Cell Biology 217:11131128. doi:10.1083/jcb.201709064

Vida T, Gerhardt B. 1999. A Cell-Free Assay Allows Reconstitution of Vps33pDependent Transport to the Yeast Vacuole/Lysosome. J Cell Biol 146:85-98. 
980 Vida TA, Emr SD. 1995. A new vital stain for visualizing vacuolar membrane dynamics and endocytosis in yeast. The Journal of cell biology 128:779-92.

983

984

985

986

987

988

989 doi:10.1083/JCB.128.5.779

Walther TC, Aguilar PS, Fröhlich F, Chu F, Moreira K, Burlingame AL, Walter P. 2007. Pkh-kinases control eisosome assembly and organization. The EMBO journal 26:4946-55. doi:10.1038/sj.emboj.7601933

Watanabe S, Boucrot E. 2017. Fast and ultrafast endocytosis. Current Opinion in Cell Biology 47:64-71. doi:10.1016/j.ceb.2017.02.013

Ziółkowska NE, Karotki L, Rehman M, Huiskonen JT, Walther TC. 2011. Eisosomedriven plasma membrane organization is mediated by BAR domains. Nature

990 structural \& molecular biology 18:854-856. doi:10.1038/nsmb.2080 
bioRxiv preprint doi: https://doi.org/10.1101/342030; this version posted January 27, 2021. The copyright holder for this preprint (which was not certified by peer review) is the author/funder, who has granted bioRxiv a license to display the preprint in perpetuity. It is made available under aCC-BY-NC-ND 4.0 International license.

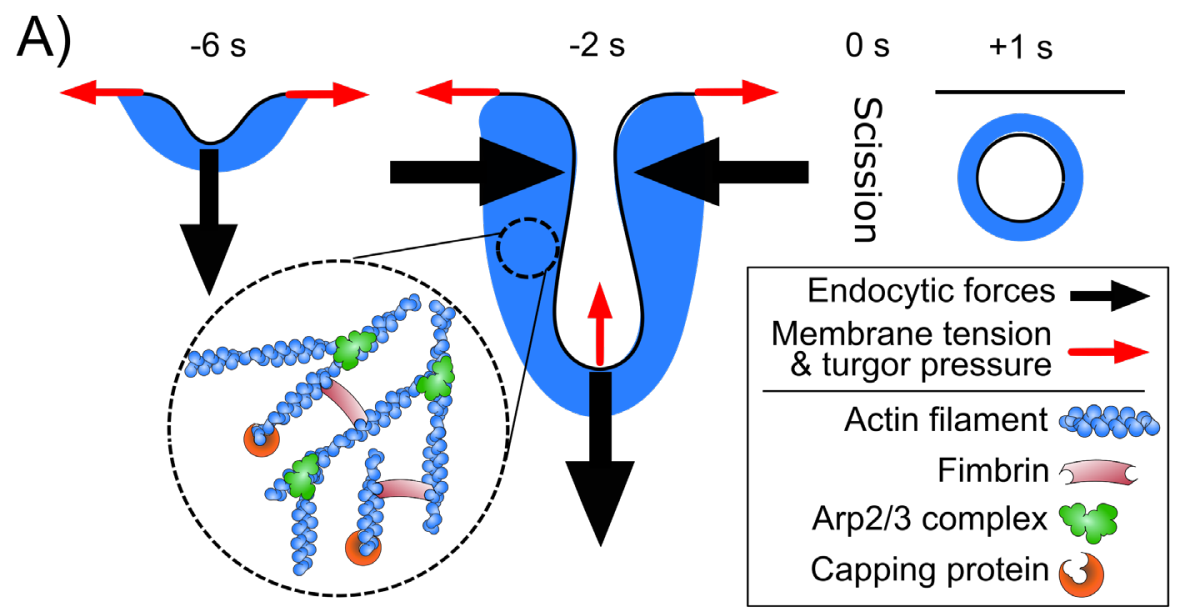

B)

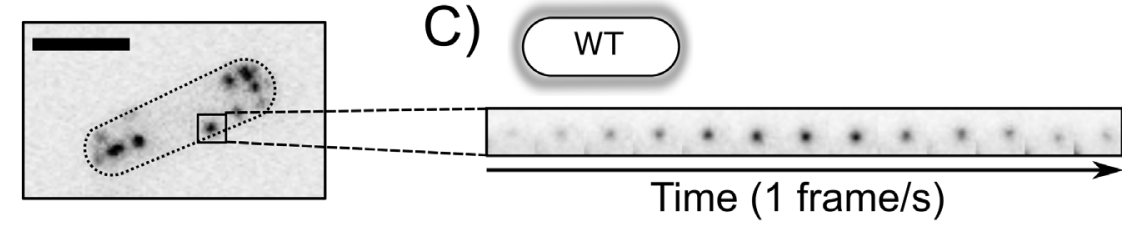

D)
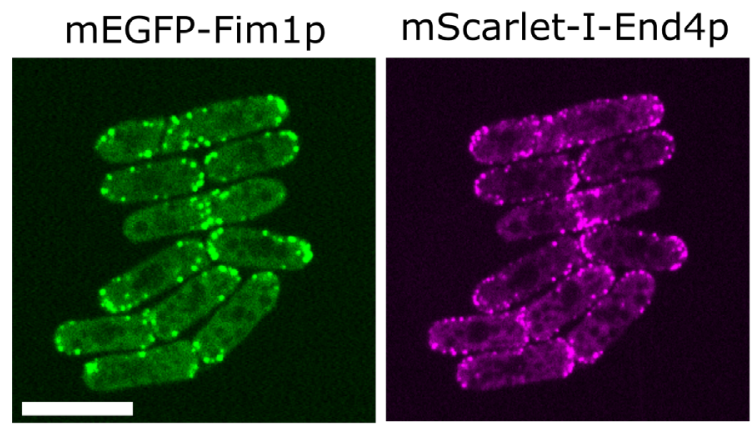

Merge

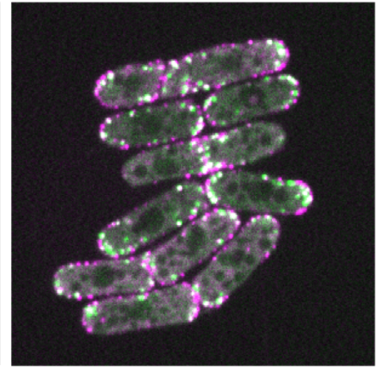

E)

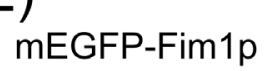

mScarlet-I-End4p

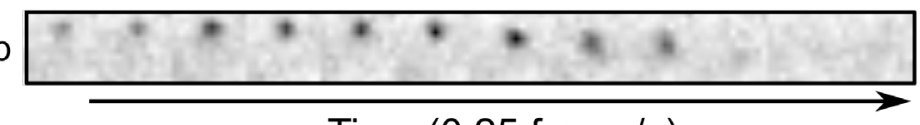

F)

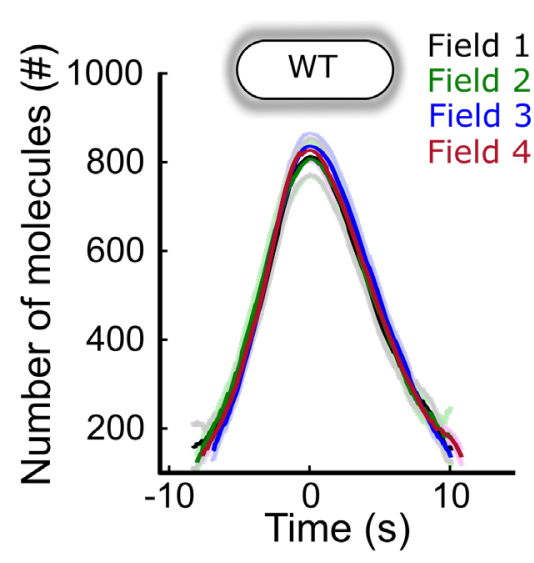

G)

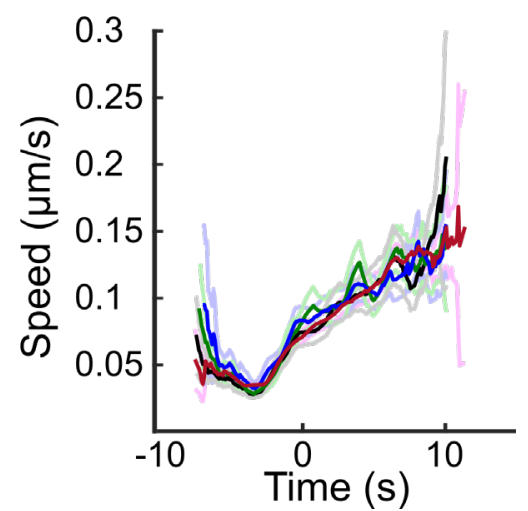


bioRxiv preprint doi: https://doi.org/10.1101/342030; this version posted January 27, 2021. The copyright holder for this preprint (which was not certified by peer review) is the author/funder, who has granted bioRxiv a license to display the preprint in perpetuity. It is made available under

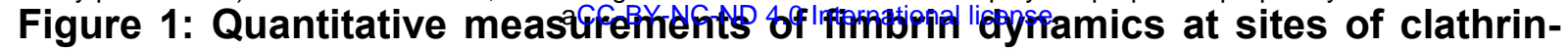
mediated endocytosis are highly reproducible. A) Schematic of the plasma membrane deformations and the main components of the actin machinery during CME. Fimbrin (Fim1p, red) crosslinks actin filaments (blue) present at endocytic sites and is used as a proxy to monitor the amount of actin assembled. B) Wild-type yeast cell expressing Fim1p-mEGFP (inverted contrast). C) Montage of a representative CME event. The interval between each frame is $1 \mathrm{~s}$. D) Colocalization of Fimbrin (mEGFP. Fim1p, green) and End4 (mScarlet-I-End4p, red) during endocytosis. Significant overlapping of signals can be seen in the merged channel. E) Montage of a representative CME event tagged by both mEGFP-Fim1p (top-row) and mScarlet-IEnd4p (bottom row). The interval between each frame is $4 \mathrm{~s}$. F) and $\mathrm{G}$ ) The number of molecules (F) and speed (G) of Fim1p-mEGFP detected, tracked and aligned with temporal super-resolution (Berro \& Pollard, 2014) is highly reproducible between fields of view (one-way ANOVA on the number of molecules at time $0 \mathrm{~s}, \mathrm{p}=0.74$ ). Each curve with a dark color represents the average of several endocytic events from a different field of view of the same sample $(\mathrm{N} \geq 64)$, and the light colors are the $95 \%$ confidence intervals. For each average curve, the peak value corresponds to time $0 \mathrm{sec}$, when vesicles scission happens. The data for each field are plotted separately in Figure 1 Supplement 1. The numbers of endocytic events used in each curve are given in Supplemental Table 2. Scale bars in (B) and (F): $5 \mu \mathrm{m}$. 
bioRxiv preprint doi: https://doi.org/10.1101/342030; this version posted January 27, 2021. The copyright holder for this preprint (which was not certified by peer review) is the author/funder, who has granted bioRxiv a license to display the preprint in perpetuity. It is made available under

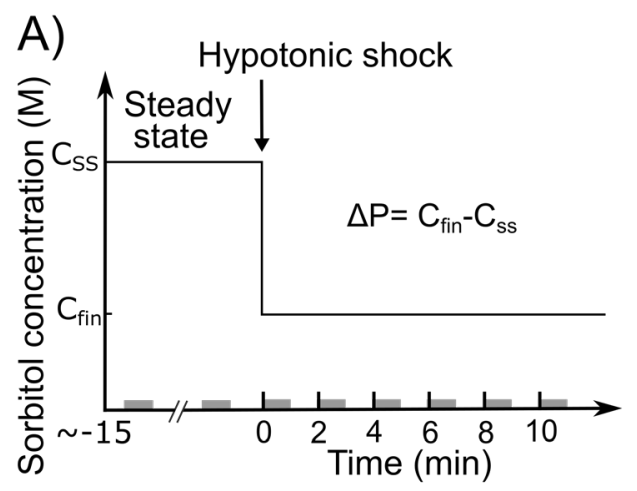

C)

WT WT

D) 0 min after a $\Delta P=-1.2 \mathrm{M}$ shock
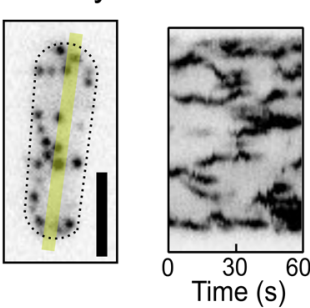

B)

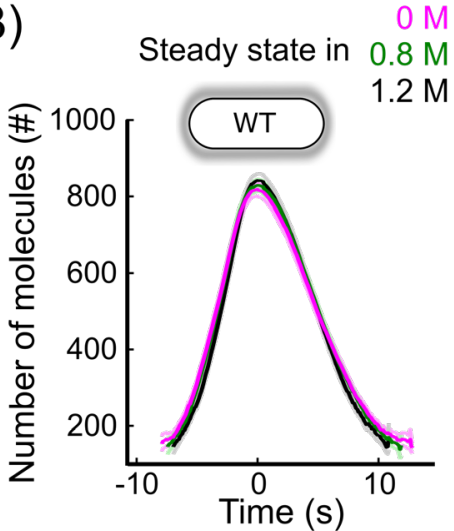

E) Steady state in $1.2 \mathrm{M}$

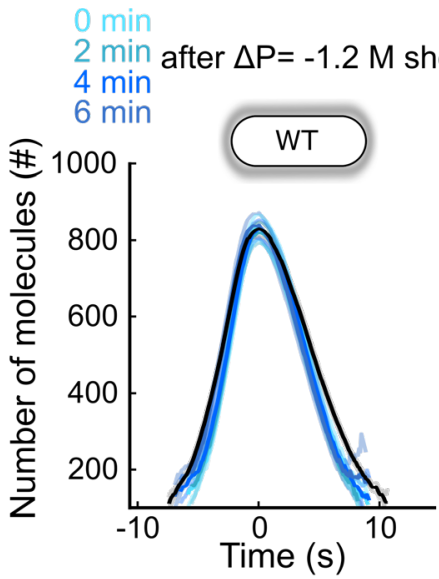

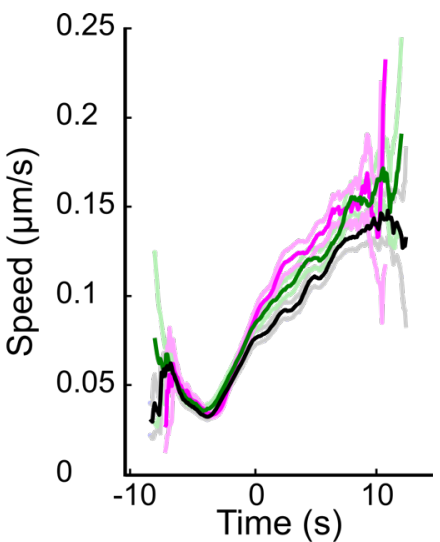

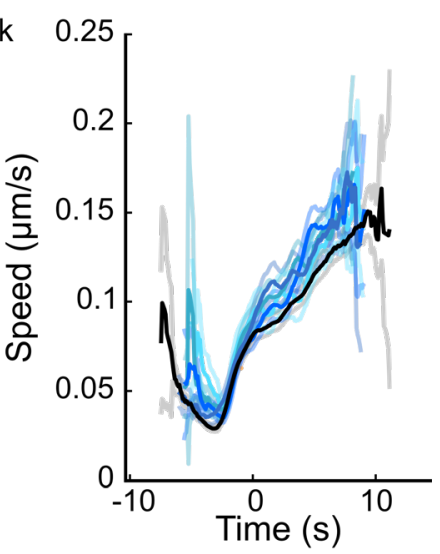

Figure 2: CME in wild-type walled cells is robust over a wide range of osmotic conditions. A) Timeline of the experiments and notations. By convention, hypotonic shocks start at time $0 \mathrm{~min}$ and are defined by the difference in concentration of sorbitol in the steady state media before the shock (Css) and after the hypotonic shock ( $\left.\mathrm{C}_{\text {fin }}\right)$, $\Delta \mathrm{P}=\mathrm{C}_{\text {fin-}}-\mathrm{Css}_{\text {ss. }}$. Data for a given time point correspond to endocytic events happening within 1 minute after this time point (e.g. the data at $t=0$ min correspond to endocytic events happening between 0 and 1 min after the shock). These time intervals are represented by gray bars on the time axis. B) Number of molecules (left panel) and speed (right panel) of Fim1p-mEGFP in wild-type walled cells at steady state in media supplemented with different sorbitol concentrations. There is no statistically significant difference in the number of molecules at time $0 \mathrm{~s}$ between the three conditions (oneway ANOVA, $p=0.29$ ). $N \geq 388$. Data for each condition are plotted separately in Figure 2 Supplement $1 \mathrm{~A}$. The numbers of endocytic events used in each curve are given in Supplemental Table 3. C) and D) Left panels: representative wild-type walled cells expressing Fim1p-mEGFP (inverted contrast) at steady state in $1.2 \mathrm{M}$ sorbitol (D) and immediately $(0 \mathrm{~min})$ after an acute osmotic shock $\Delta P=-1.2 \mathrm{M}(\mathrm{E})$. Right panels: kymographs of the fluorescence under the yellow line in the left panels. Black dashed lines: outline of the cell. Scale bars for all panels: $5 \mu \mathrm{m}$. E) Number of molecules (left panel) and speed (right panel) of Fim1p-mEGFP for wild-type walled cells initially at steady state in $1.2 \mathrm{M}$ sorbitol and after an acute osmotic shock of $\Delta \mathrm{P}=-1.2 \mathrm{M}$. There is no statistically significant difference in the number of molecules at time $0 \mathrm{~s}$ between the three conditions (one-way ANOVA, $\mathrm{p}=0.95$ ). Black: steady state in $1.2 \mathrm{M}$ sorbitol; light to dark blue in top panel: $0 \mathrm{~min}, 2 \mathrm{~min}, 4 \mathrm{~min}$, and $6 \mathrm{~min}$ after the acute hypotonic 
bioRxiv preprint doi: https://doi.org/10.1101/342030; this version posted January 27, 2021. The copyright holder for this preprint (which was not certified by peer review) is the author/funder, who has granted bioRxiv a license to display the preprint in perpetuity. It is made available under

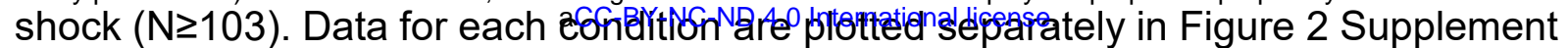
1B. The numbers of endocytic events used in each curve are given in Supplemental Table 4. (B) and (E): dark colors: average; light colors: average $+/-95 \%$ confidence interval. 
bioRxiv preprint doi: https://doi.org/10.1101/342030; this version posted January 27, 2021. The copyright holder for this preprint (which was not certified by peer review) is the author/funder, who has granted bioRxiv a license to display the preprint in perpetuity. It is made available under

A)

Steady state in $1.2 \mathrm{M}$

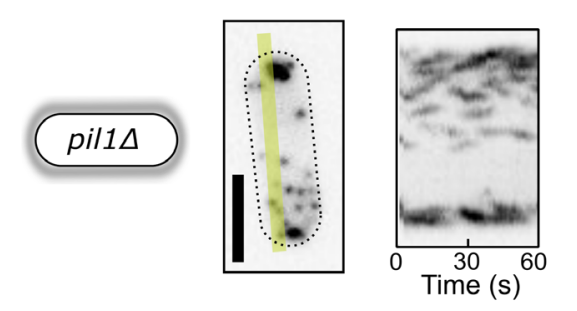

C)

0 min after a $\Delta P=-1.2 \mathrm{M}$ shock
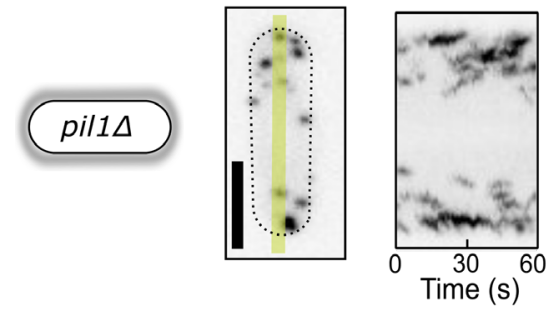

B)

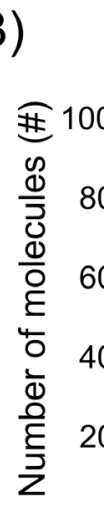

$0 \mathrm{M}$

Steady state in $0.8 \mathrm{M}$

D) Steady state in $1.2 \mathrm{M}$

0 min

4 min

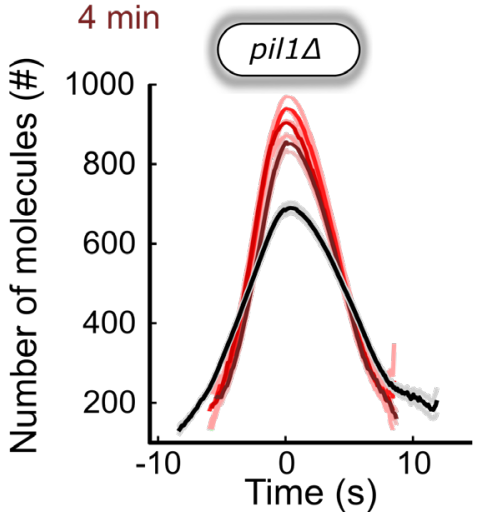

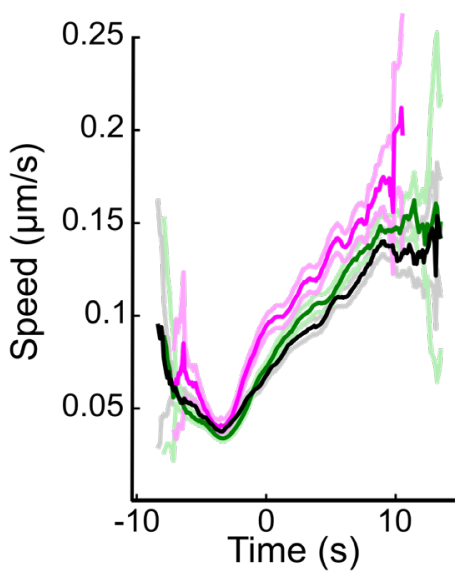

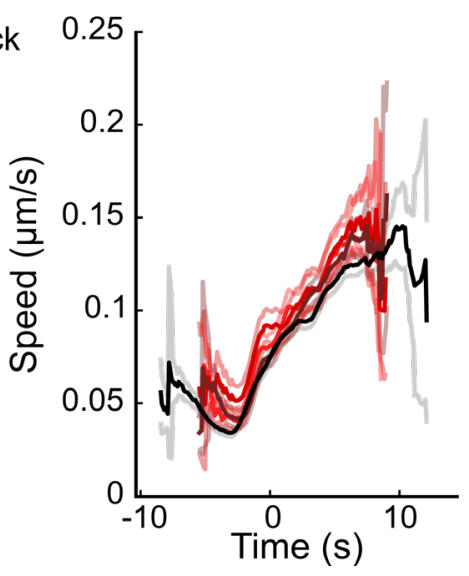

Figure 3: The absence of eisosome makes the dynamics of the CME machinery more sensitive to changes in osmolarity. A) and C) Left panels: representative pil1 $\Delta$ walled cells expressing Fim1p-mEGFP (inverted contrast) at steady state in 1.2 $\mathrm{M}$ sorbitol $(\mathrm{A})$ and immediately $(0 \mathrm{~min})$ after an acute osmotic shock of $\Delta \mathrm{P}=-1.2 \mathrm{M}$ (C). Right panels: kymographs of the fluorescence under the yellow lines in the left panels. Black dashed lines: cell outline. Scale bars: $5 \mu \mathrm{m}$. B) Number of molecules (left panel) and speed (right panel) of Fim1p-mEGFP in pil1 $\Delta$ walled cells at steady state in media supplemented with different sorbitol concentrations $(N \geq 342)$. The difference in the number of molecules at time $0 \mathrm{~s}$ between all pairs of conditions is statistically significant (one-way ANOVA, $p<10^{-5}$ ). Data for each condition are plotted separately in Figure 3 Supplement $1 \mathrm{~A}$. The numbers of endocytic events used in each curve are given in Supplemental Tables 5. D) Number of molecules (left panel) and speed (right panel) of Fim1p-mEGFP in pil1 $\Delta$ walled cells before and after an acute osmotic shock $(\triangle P=-1.2 \mathrm{M})$. The difference in the number of molecules at time $0 \mathrm{~s}$ between all pairs of conditions is statistically significant (one-way ANOVA, $p<0.03$ ) except between 0 min and 2 min after the shock (one-way ANOVA, $p=0.18$ ). Black: steady state in $1.2 \mathrm{M}$ sorbitol before the hypotonic shock $(\mathrm{N}=583)$; light to dark red in top panel: $0 \mathrm{~min}, 2 \mathrm{~min}$ and $4 \mathrm{~min}$ after the acute hypotonic shock ( $\mathrm{N} \geq 145)$. Data for each condition are plotted separately in Figure 3 Supplement 1B. The numbers of endocytic events used in each curve are given in Supplemental Table 6. (B) and (D): dark colors: average; light colors: average $+/-95 \%$ confidence interval. 
bioRxiv preprint doi: https://doi.org/10.1101/342030; this version posted January 27, 2021. The copyright holder for this preprint (which was not certified by peer review) is the author/funder, who has granted bioRxiv a license to display the preprint in perpetuity. It is made available under
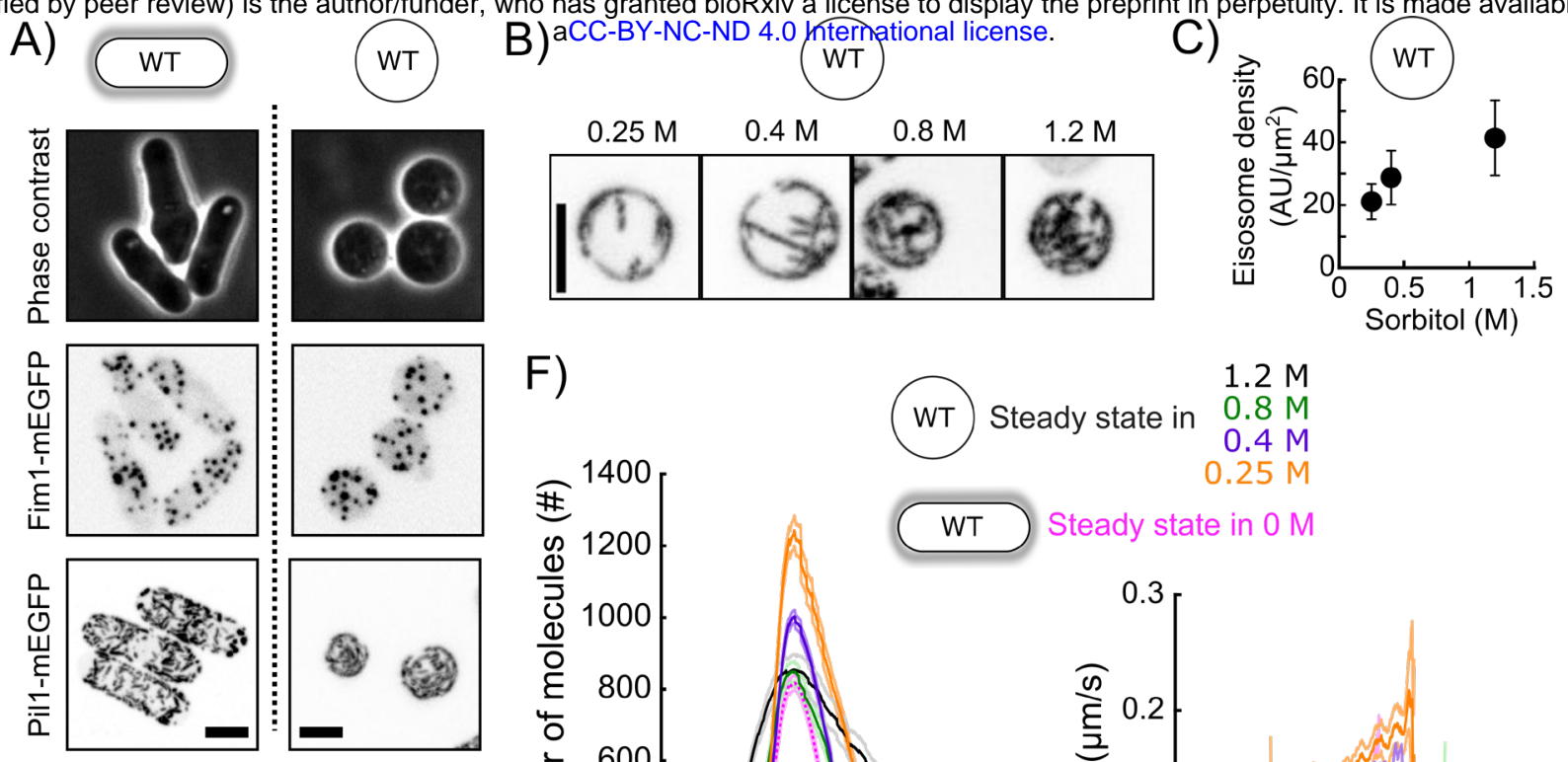

D)
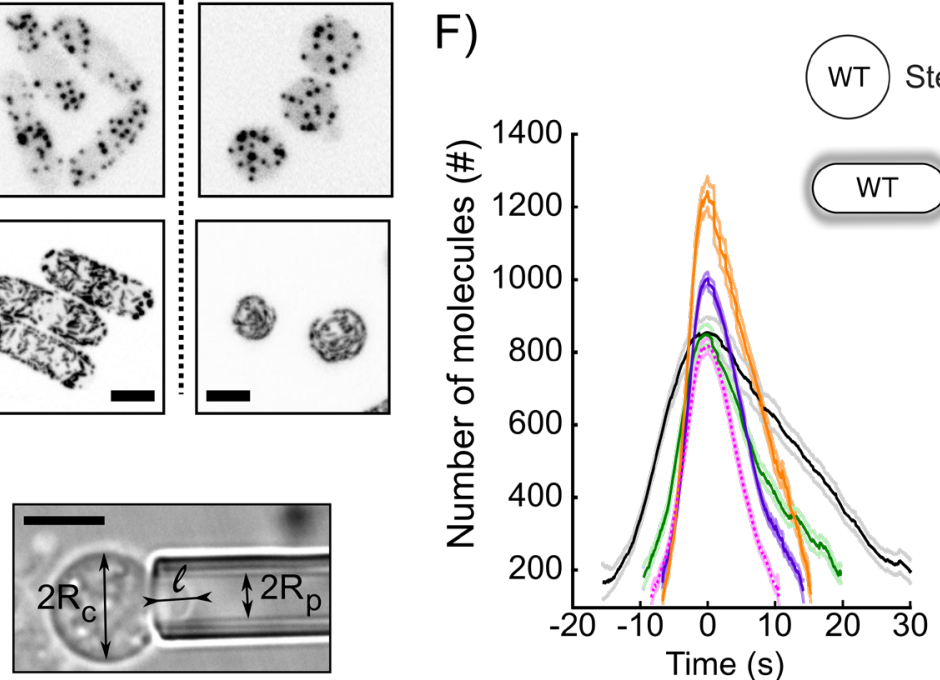

E)

G)
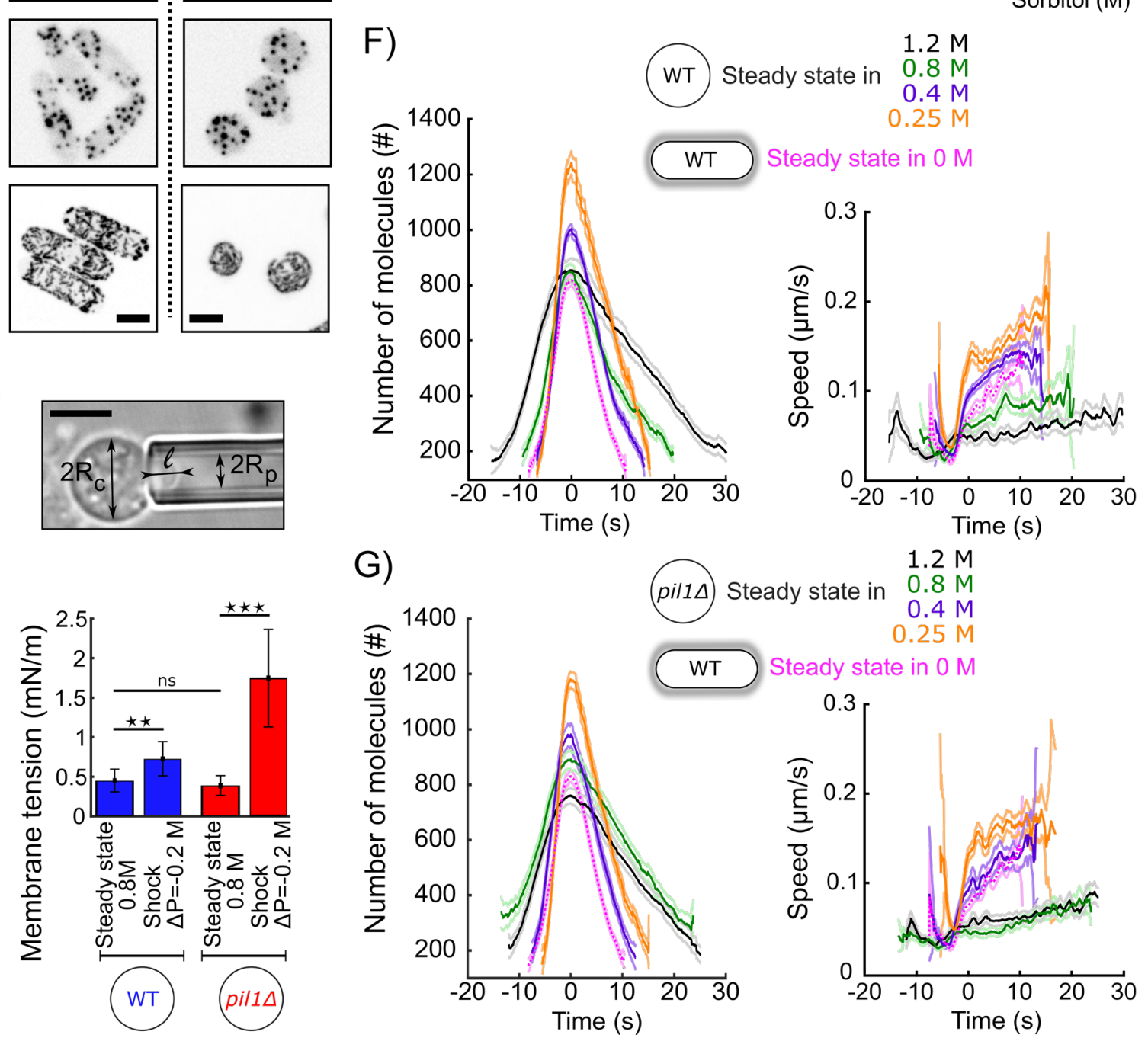

$1.2 \mathrm{M}$

$0.8 \mathrm{M}$

$0.25 \mathrm{M}$

Steady state in $0 \mathrm{M}$

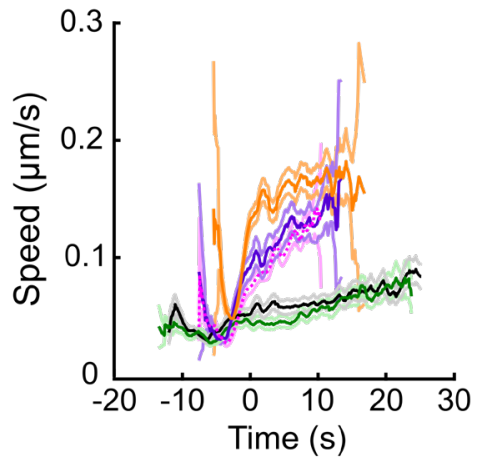

H)
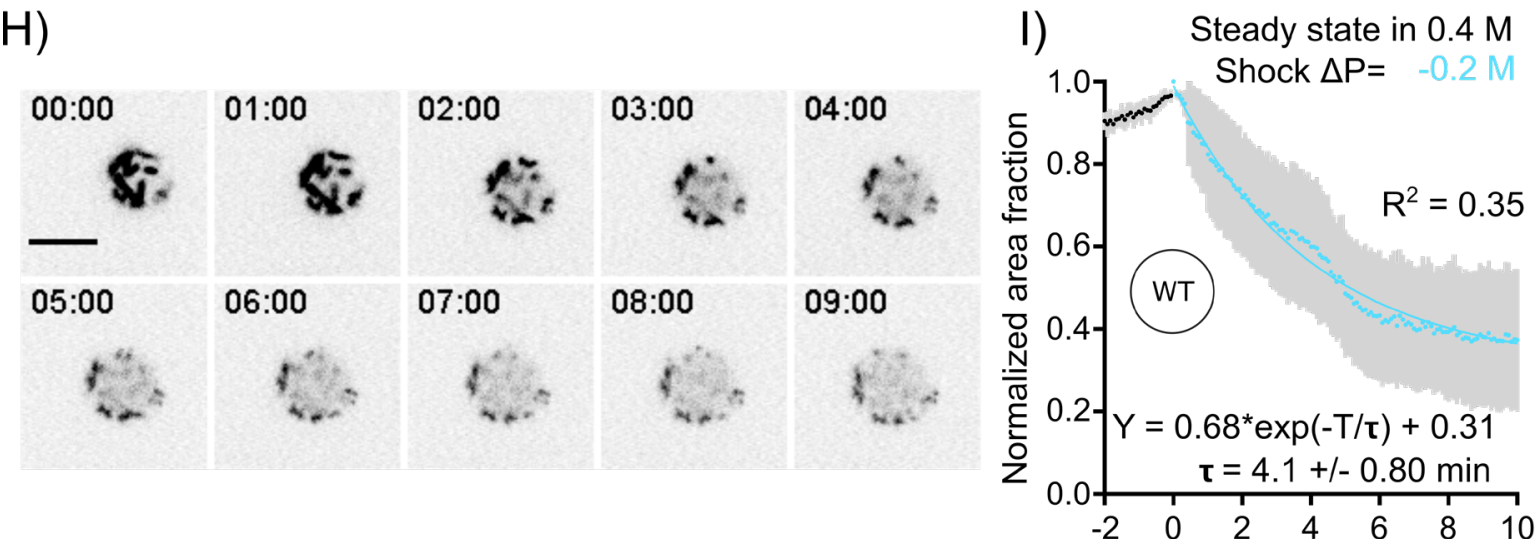
bioRxiv preprint doi: https://doi.org/10.1101/342030; this version posted January 27, 2021. The copyright holder for this preprint (which was not certified by peer review) is the author/funder, who has granted bioRxiv a license to display the preprint in perpetuity. It is made available under

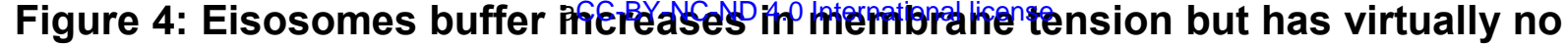
influence on the dynamics of the actin endocytic machinery at steady state in protoplasts. A) Representative walled yeast cells (left column) and protoplasts (right column) at steady state in $1.2 \mathrm{M}$ sorbitol. Top panels: phase contrast; middle panels: cells expressing Fim1-mEGFP (inverted contrast); bottom panels: cells expressing Pil1-mEGFP (inverted contrast). Note that the expression of pil1-mEGFP is the same in walled cells and protoplasts (Figure 4 Supplement 1). B) Eisosomes labelled with Pil1p-mEGFP (inverted contrast) in wild-type protoplasts at steady state in different sorbitol concentrations. From left to right: $0.25 \mathrm{M}, 0.4 \mathrm{M}, 0.8 \mathrm{M}$ and $1.2 \mathrm{M}$ sorbitol. C) Density of eisosomes at the plasma membrane, measured as the ratio between the intensity of Pil1p-mEGFP on the plasma membrane and the surface area of the protoplast, at steady state in $0.25 \mathrm{M}(\mathrm{N}=26), 0.4 \mathrm{M}(\mathrm{N}=34)$ and $1.2 \mathrm{M}(\mathrm{N}=39)$ sorbitol. Error bars: standard deviations. D) Micropipette aspiration was used to measure membrane tension. $R_{c}$ : cell radius; $R_{p}$ : micropipette radius; I: length of the tongue inside the micropipette. E) Membrane tension of protoplasts at steady state in $0.8 \mathrm{M}$ sorbitol and $\sim 5$ min after a hypotonic shock $(\triangle P=-0.2 M)$ for wild-type (blue bars, $N=28$ for steady state and $\mathrm{N}=5$ for the shock) and pil1 $\Delta$ protoplasts (red bars, $\mathrm{N}=42$ for steady state and $\mathrm{N}=7$ for the shock). Error bars: standard deviation. $\mathrm{p}$-values: non-significant (ns), p>0.05; two stars $\left({ }^{* *}\right), p \leq 0.01$; three stars $\left(^{* * *}\right), p \leq 0.001$. F) and G) Number of molecules (left panels) and speed (right panels) of Fim1p-mEGFP for wild-type $(F)$ and pil1 $(\mathrm{G})$ protoplasts at steady state in different sorbitol concentrations. Orange: 0.25 $\mathrm{M}$; purple: 0; green: 0.8 M; black: 1.2 M. Dark colors: average; light colors: average +/$95 \%$ confidence interval $(\mathrm{N} \geq 143)$. Fuchsia dotted curves: wild-type walled cells at steady state in $0 \mathrm{M}$ sorbitol. Data for each condition are plotted separately in Figure 4 Supplement 2. The numbers of endocytic events used in each curve are given in Supplemental Table 7. H) and I) Eisosomes of wild-type protoplasts disassemble rapidly after a hypotonic shock. $(\mathrm{H})$ Time course of a representative protoplast expressing Pil1p-mEGFP over 10 minutes after a hypotonic shock $(\triangle P=-0.2 M)$ and initially at steady-state in $0.4 \mathrm{M}$ sorbitol (just before time $0 \mathrm{~min}$ ). (I) Evolution of the surface area covered by eisosomes over time, as a fraction of the surface area covered at time 0 min (normalized to 1). Data are from three independent experiments $(N=15)$ and presented as mean $+/-95 \%$ confidence interval. Scale bars in (A), (B), (D) and (I): $5 \mu \mathrm{m}$. 
bioRxiv preprint doi: https://doi.org/10.1101/342030; this version posted January 27, 2021. The copyright holder for this preprint (which was not certified by peer review) is the author/funder, who has granted bioRxiv a license to display the preprint in perpetuity. It is made available under

A)

Steady state in $0.4 \mathrm{M}$

aCC-BY-NC-NB 4.0 Integnetionaldicilents $\triangle P=-0.1 \mathrm{M}$ shock
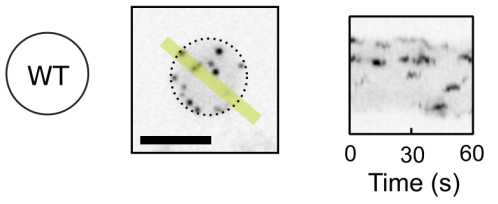

$\Delta \mathrm{P}=-0.05 \mathrm{M}$

C)

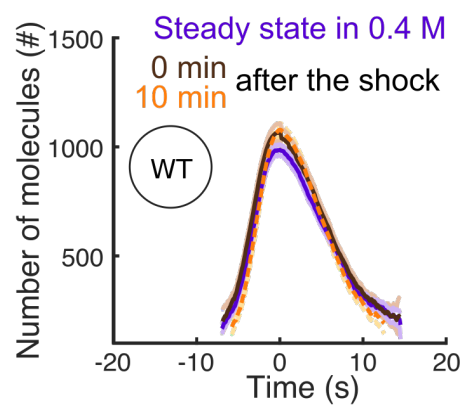

E)
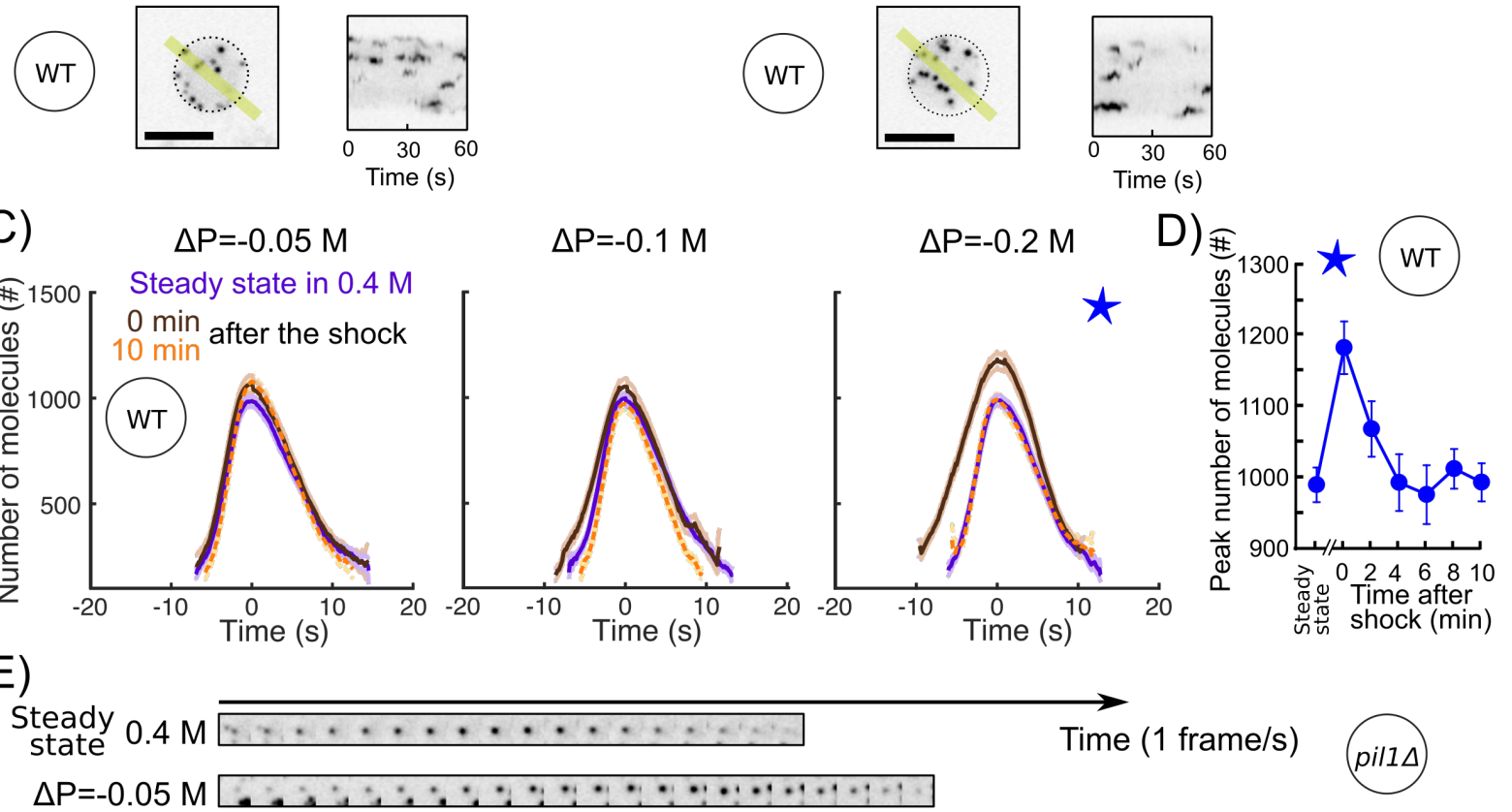

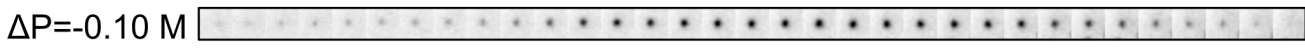

$\Delta \mathrm{P}=-0.20 \mathrm{M}$

F)

$\Delta \mathrm{P}=-0.05 \mathrm{M}$

$\Delta P=-0.1 \mathrm{M}$

$\Delta P=-0.2 \mathrm{M}$

Steady state in $0.4 \mathrm{M}$
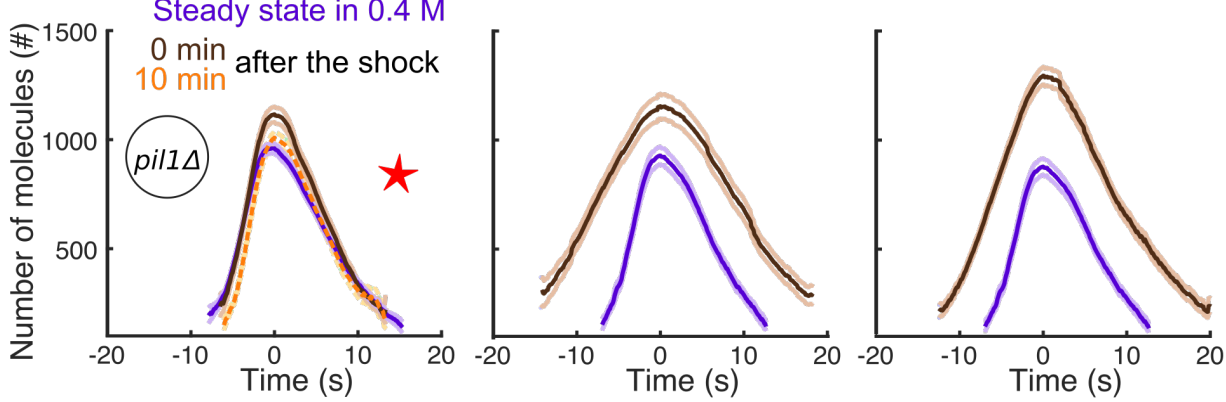

G)

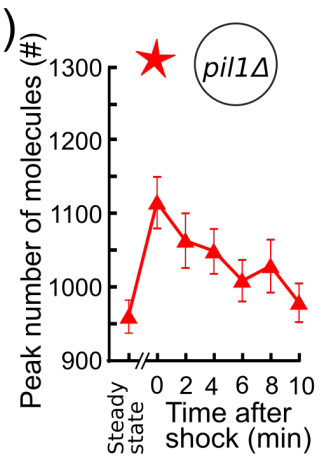

$\mathrm{H}$

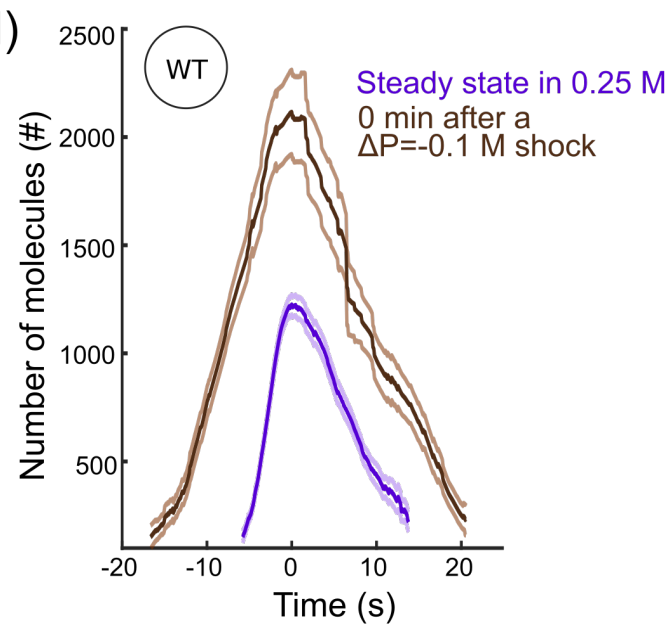

I) 2500 pil1 1 Steady state in $0.25 \mathrm{M}$

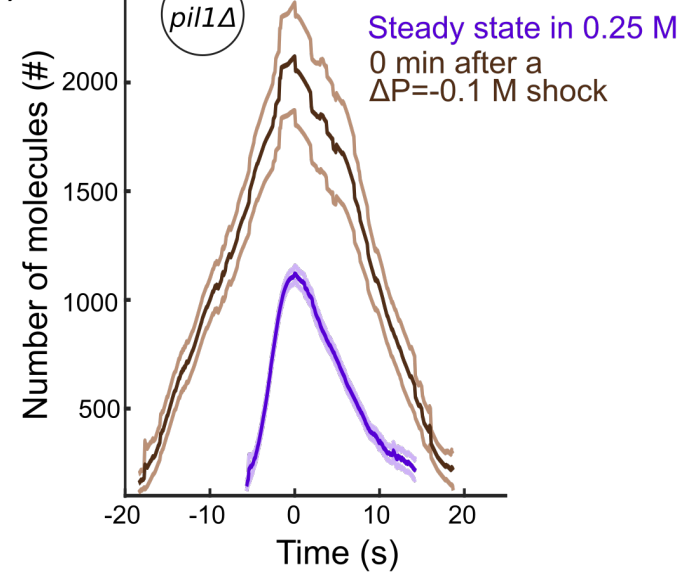


bioRxiv preprint doi: https://doi.org/10.1101/342030; this version posted January 27, 2021. The copyright holder for this preprint (which was not certified by peer review) is the author/funder, who has granted bioRxiv a license to display the preprint in perpetuity. It is made available under

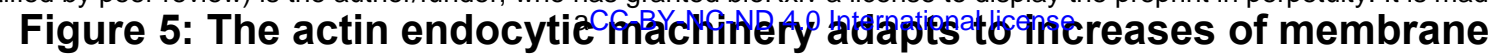

tension in protoplasts. A) and B) Representative wild-type protoplasts expressing Fim1-mEGFP (inverted contrast) at steady-state in $0.25 \mathrm{M}$ sorbitol (A, left panel) and immediately after ( $0 \mathrm{~min})$ an acute osmotic shock of $\triangle P=-0.1 \mathrm{M}$ ( $\mathrm{B}$, left panel). Right panels: kymographs of the fluorescence under the yellow lines in the left panels.

Black dashed lines: protoplast outline. Scale bars: $5 \mu \mathrm{m}$. C) and F) Number of Fim1pmEGFP molecules in wild-type $(C)$ and pil $1 \Delta(F)$ protoplasts at steady-state in $0.4 \mathrm{M}$ sorbitol (purple), $0 \mathrm{~min}$ (brown) and $10 \mathrm{~min}$ (orange) after an hypotonic shock of $\Delta \mathrm{P}=-$ $0.05 \mathrm{M}$ (left panels), $\Delta \mathrm{P}=-0.1 \mathrm{M}$ (middle panels) and $\Delta \mathrm{P}=-0.2 \mathrm{M}$ (right panels), $\mathrm{N} \geq 95$. Data for each condition are plotted separately in Figure 5 Supplements 1 (wild type) and 2 (pil1 $\Delta$ ). The speeds of Fim1p-mEGFP for each condition are shown in Figure 5 Supplements 3 (wild type) and 4 (pil1 $\Delta$ ). The numbers of endocytic events used in each curve are given in Supplemental Table 8. Note that the large majority of pil1 $\Delta$ protoplasts were too damaged or dead 2 minutes after hypotonic shocks larger than or equal to $\Delta \mathrm{P}=-0.1 \mathrm{M}$ to allow us to track enough endocytic events and produce a curve (Figures 6B and C, Figure 6 Supplement 1). In panel (C), the difference in the number of molecules at time $0 \mathrm{~s}$ at steady state and 0 min after the shock is statistically significant for all shocks (one-way ANOVA, $p<0.03$ ) and the difference between steady-state and 10 min after the shock is not statistically significant (oneway ANOVA, $p>0.2$; details in the data file for figure $5 C$ ). In panel $(F)$, the difference at steady state and 0 min after the shock is statistically significant for all shocks (oneway ANOVA, $p<10^{-5}$; details in the data file for figure $5 \mathrm{~F}$ ). D) Temporal adaptation of the peak number of Fim1p-mEGFP in wild-type protoplasts initially at steady state in $0.4 \mathrm{M}$ sorbitol and 0 to $10 \mathrm{~min}$ after a $\Delta P=-0.2 \mathrm{M}$ osmotic shock. The condition for this figure is the same as the condition with the blue star in (C). The difference between steady-state and 0 min or 2 min after shock is statistically significant (one-way ANOVA, $p<10^{-3}$; details in the data file for figure $5 \mathrm{D}$ ). The difference between steadystate and $4 \mathrm{~min}, 6 \mathrm{~min}, 8 \mathrm{~min}$ and $10 \mathrm{~min}$ after shock is not statistically significant (one-way ANOVA, $p>0.2$; details in the data file for figure $5 \mathrm{D}$ ). E) Montage of representative endocytic events (Fim1-mEGFP, inverted contrast) in pil1 $\Delta$ protoplasts ( 1 frame per second) at steady state in $0.4 \mathrm{M}$ sorbitol (first row) and immediately after $(0 \mathrm{~min})$ a hypotonic shocks of $\Delta \mathrm{P}=-0.05 \mathrm{M}$ (second row), $\Delta \mathrm{P}=-0.10$ $\mathrm{M}$ (third row) and $\triangle P=-0.20 \mathrm{M}$ (fourth row).G) Temporal adaptation of the peak number of Fim1p-mEGFP in pil1 $\Delta$ protoplasts initially at steady state in $0.4 \mathrm{M}$ sorbitol and 0 to $10 \mathrm{~min}$ after a $\triangle P=-0.05 \mathrm{M}$ shock. The condition in this figure is the same as the condition with the red star in $(F)$. The difference between steady-state and $0 \mathrm{~min}$, $2 \mathrm{~min}, 4 \mathrm{~min}, 6 \mathrm{~min}$ or $8 \mathrm{~min}$ after shock is statistically significant (one-way ANOVA, $p<0.01$; details in the data file for figure $5 F$ ). The difference between steady-state and 10 min after shock is not statistically significant (one-way ANOVA, $p>0.3$; details in the data file for figure $5 \mathrm{~F}$ ). (D) and (G) error bars are $95 \%$ confidence intervals. The numbers of endocytic events at each time point are given in Supplemental Table 9.

$\mathrm{H})$ and I) Number of molecules of Fim1p-mEGFP for wild-type $(\mathrm{H})$ and pil1 $\Delta(\mathrm{I})$ protoplasts at steady state in $0.25 \mathrm{M}$ sorbitol (purple dashed) and immediately after ( 0 min) a hypotonic shock of $\Delta P=-0.1 \mathrm{M}$ (brown), $\mathrm{N} \geq 67$. The difference in the number of molecules at time $0 \mathrm{~s}$ at steady state and 0 min after the shock is statistically significant for all conditions (one-way ANOVA, $p<10^{-16}$ ). The speed data for each condition are plotted in Figure 5 Supplement 5 . The numbers of endocytic events used in each curve are given in Supplemental Table 10. The survival rates for the wild-type and pil $1 \Delta$ protoplasts in these conditions are plotted in Figure 5- 
bioRxiv preprint doi: https://doi.org/10.1101/342030; this version posted January 27, 2021. The copyright holder for this preprint (which was not certified by peer review) is the author/funder, who has granted bioRxiv a license to display the preprint in perpetuity. It is made available under Supplement $5 \mathrm{C}$.

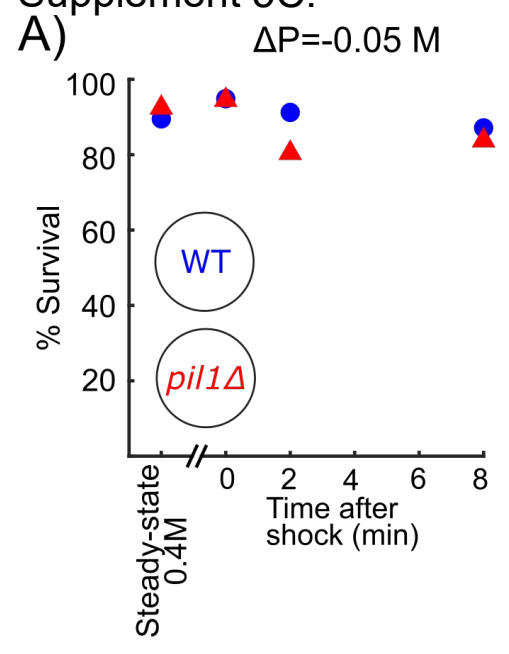

B)

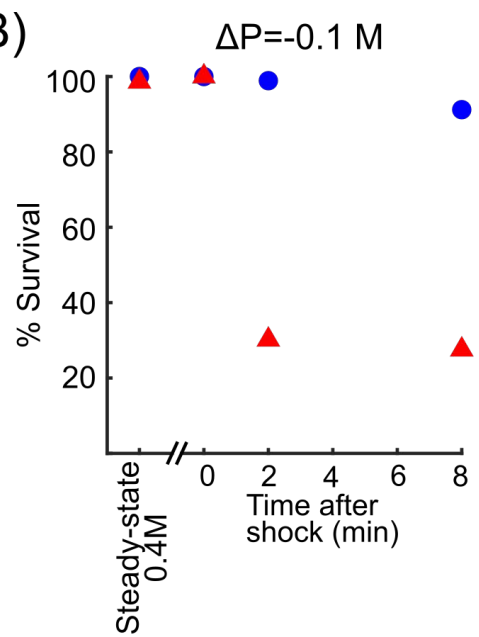

C)

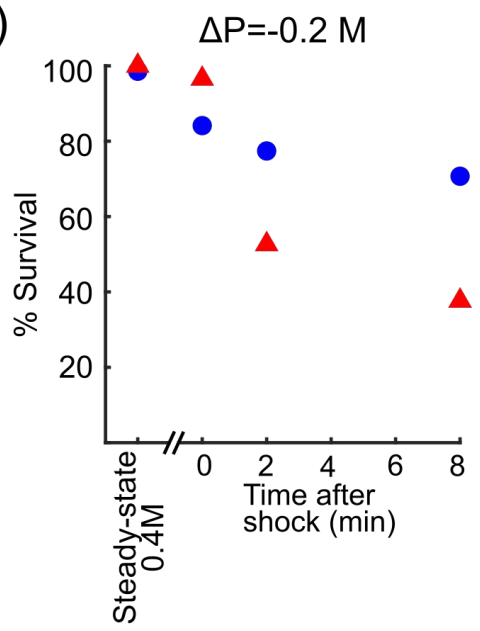

D)

F)

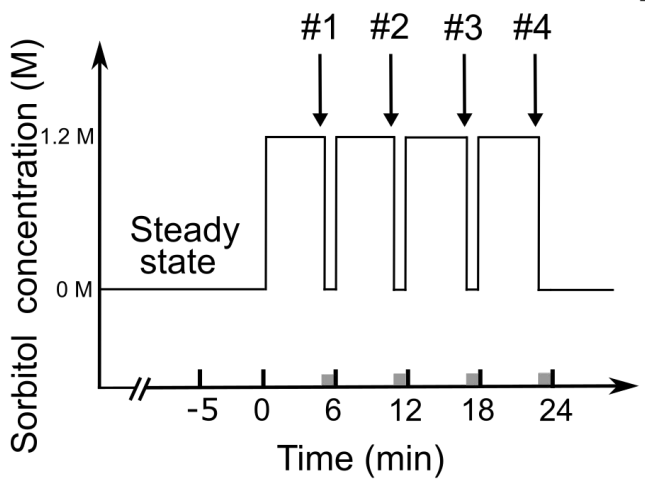

Before shock

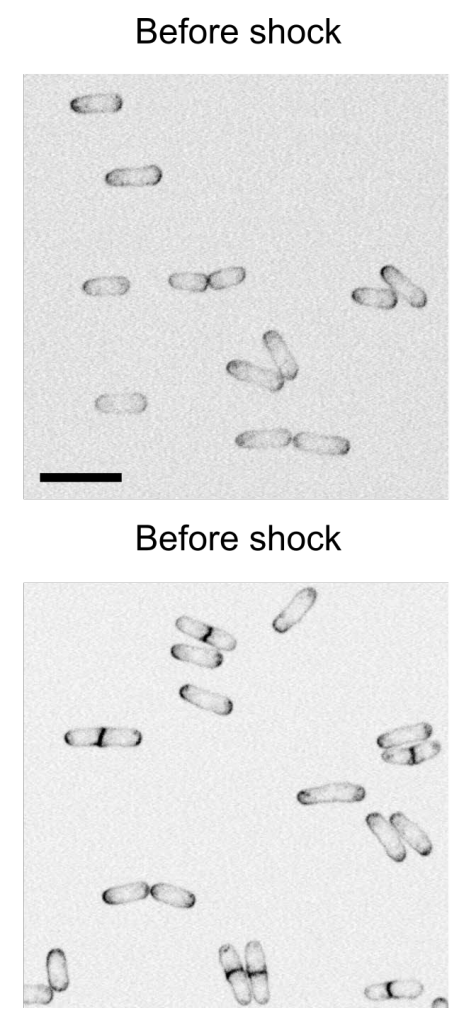

Before shock

$$
\text { pil1 } \Delta
$$

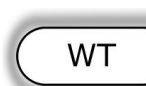

E)

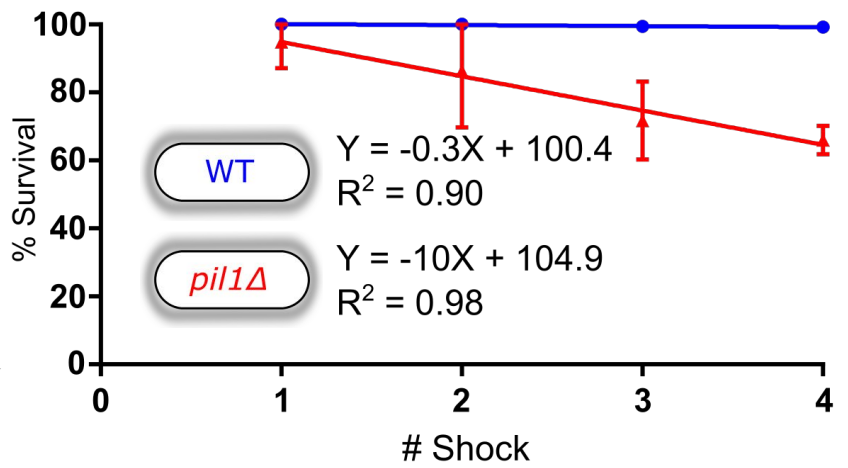

After 4th shock

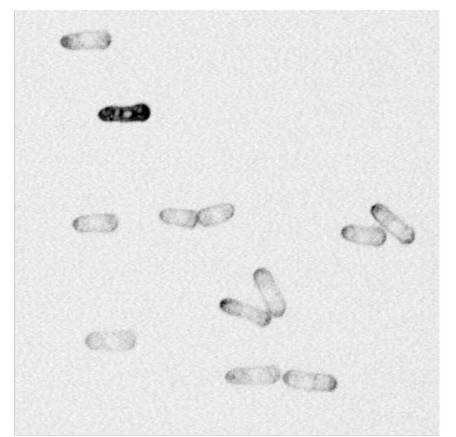

After 4th shock

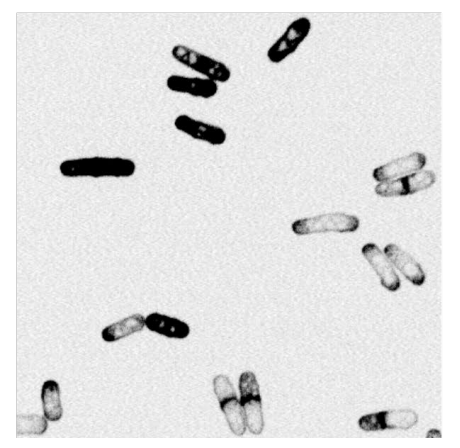


bioRxiv preprint doi: https://doi.org/10.1101/342030; this version posted January 27, 2021. The copyright holder for this preprint (which was not certified by peer review) is the author/funder, who has granted bioRxiv a license to display the preprint in perpetuity. It is made available under

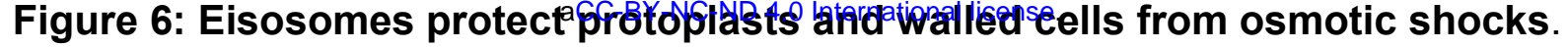

A-C) Percentage of wild-type (blue dots) and pil1 $\Delta$ (red triangle) protoplasts that are alive at steady-state in $0.4 \mathrm{M}$ sorbitol, and after a $\triangle P=-0.05 \mathrm{M}(\mathrm{A}), \Delta \mathrm{P}=-0.1 \mathrm{M}(\mathrm{B})$ and $\Delta P=-0.2 M(C)$ single hypotonic shock. Representative fields of view used to determine these percentages are shown in Figure 6 Supplement 1. D) Timeline of repeated $\Delta \mathrm{P}=1.2 \mathrm{M}$ osmotic shocks for walled cells. Each osmotic shock was performed by exchanging sorbitol concentration from $1.2 \mathrm{M}$ (5 minutes) to $0 \mathrm{M}(1$ minute). E) Percentage of wild-type (blue dots, $\mathrm{N}=273$ ) and pil1 $\Delta$ (red triangle, $\mathrm{N}=197$ ) walled cells that are alive after each osmotic shock. Note the progressive cell death induced by repeated osmotic shocks for pil1 $\Delta$ cells. Combined data are from three independent experiments and plotted as mean $+/$ - standard deviation. F)

Representative images of wild-type (upper panel) and pil1 $\Delta$ (lower panel) walled cells before shock and after the $4^{\text {th }}$ shock. Dead cells are strongly stained by FM4-64 due to membrane damage. Scale bar: $10 \mu \mathrm{m}$. 
bioRxiv preprint doi: https://doi.org/10.1101/342030; this version posted January 27, 2021. The copyright holder for this preprint (which was not certified by peer review) is the author/funder, who has granted bioRxiv a license to display the preprint in perpetuity. It is made available under

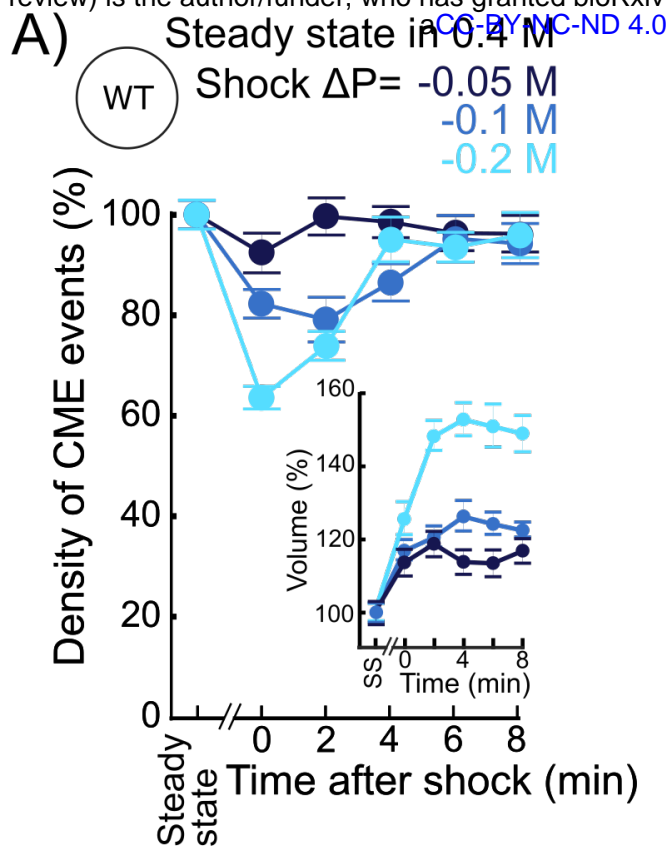

C) $\quad 2$ Steady state in $1.2 \mathrm{M}$
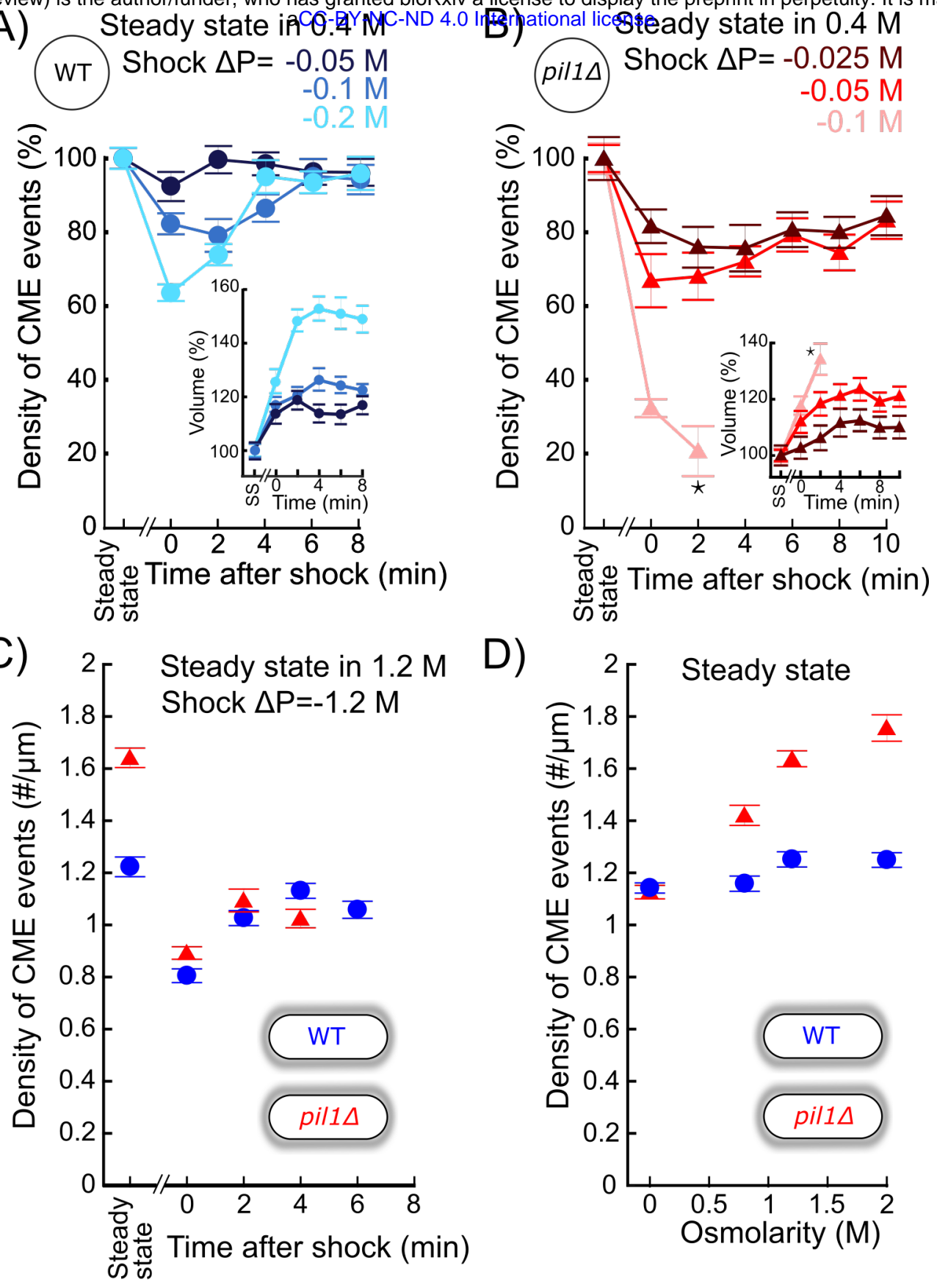

Figure 7: The density of endocytic events rapidly adapts after acute osmotic shocks. A) Temporal evolution of density of endocytic events (average number of endocytic events at a given time in a cell divided by the cell length) in wild-type protoplasts initially at steady state in $0.4 \mathrm{M}$ sorbitol and after an acute hypotonic shock of $\Delta P=-0.05 \mathrm{M}$ (dark blue, $\mathrm{N}_{\text {cell }} \geq 102$ ), $\Delta \mathrm{P}=-0.1 \mathrm{M}$ (blue, $\mathrm{N}_{\text {cell }} \geq 54$ ) and $\Delta \mathrm{P}=-0.2 \mathrm{M}$ (light blue, $N_{\text {cell }} \geq 83$ ). For $\Delta P=-0.1 M$ and $\Delta P=-0.2 M$, the difference in the density of CME events between steady-state and $0 \mathrm{~min}$ or $2 \mathrm{~min}$ after the shock is statistically significant (one-way ANOVA, $p<10^{-4}$ ). In all conditions, the difference after 6 min is not significant (one-way ANOVA, $p>0.12$; details in the data file). B) Same as (A) but with pil1 $\Delta$ protoplasts and hypotonic shocks of $\Delta P=-0.025 \mathrm{M}$ (dark red, $N_{\text {cell }} \geq 70$ ), $\Delta P=-0.05$ $\mathrm{M}$ (red, $\mathrm{N}_{\text {cell }} \geq 103$ ) and $\Delta P=-0.1 \mathrm{M}$ (light red, $\mathrm{N}_{\text {cell }} \geq 78$ ). In all conditions, the difference in the density of CME events between steady-state and any time after the shock is statistically significant (one-way ANOVA, $p<10^{-3}$ ). For $\Delta P=-0.025 \mathrm{M}$ and $\triangle \mathrm{P}=-0.05 \mathrm{M}$, 
bioRxiv preprint doi: https://doi.org/10.1101/342030; this version posted January 27, 2021. The copyright holder for this preprint (which was not certified by peer review) is the author/funder, who has granted bioRxiv a license to display the preprint in perpetuity. It is made available under the differences between time Bbin $\mathrm{p}>0.09$; details in the data file). (A) and (B) insets: relative volume increase after the hypotonic shocks (the volume at steady state is used as a reference). The numbers of cells used for each condition and each time point are given in Supplemental Table 11. The number of cells measured in the insets are the same as in the main figures. Star $\left.{ }^{*}\right)$ : the large majority of pil1 $\Delta$ protoplasts were too damaged or dead 4 minutes after the hypotonic shocks at $\Delta \mathrm{P}=-0.1 \mathrm{M}$ (Figure $6 \mathrm{~B}$ ), which prevented us to measure the density of endocytic events and the volume after this time point. C) Density of endocytic events in wild-type (blue circle) and pil1 $\Delta$ (red triangle) walled cells initially at steady state in $1.2 \mathrm{M}$ sorbitol and after an acute hypotonic shock of $\Delta \mathrm{P}=-1.2 \mathrm{M}, \mathrm{N}_{\text {cell }} \geq 44$. The numbers of cells used for each condition and each time point are given in Supplemental Table 12. For willed-type and pil1 $\Delta$ walled cells, the differences in the density of CME events after 2 min are not statistically significant ( $p>0.08$; details in the data file). D) Density of endocytic events in intact cells at steady state in different osmolarities, $\mathrm{N}_{\text {cell }} \geq 80$. In pil $1 \Delta$ walled cells, the difference in the density of CME events between all pairs of conditions is statistically significant (one-way ANOVA, $p<10^{-4}$ ). In wild-type walled cells, the difference is small but statistically significant (details in the data file). (A), (B), (C) and (D): error bars are standard errors of the mean. The numbers of cells used for each condition and each time point are given in Supplemental Table 13. 
bioRxiv preprint doi: https://doi.org/10.1101/342030; this version posted January 27, 2021. The copyright holder for this preprint (which was not certified by peer review) is the author/funder, who has granted bioRxiv a license to display the preprint in perpetuity. It is made available under

A)

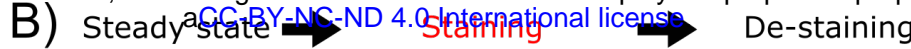

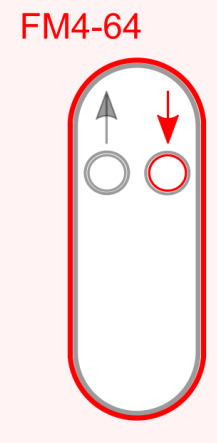

C) Steady state in $0.4 \mathrm{M}$

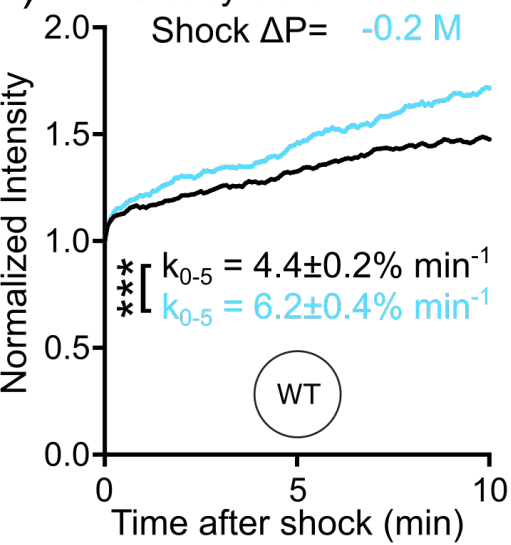

F) Steady state in $1.2 \mathrm{M}$

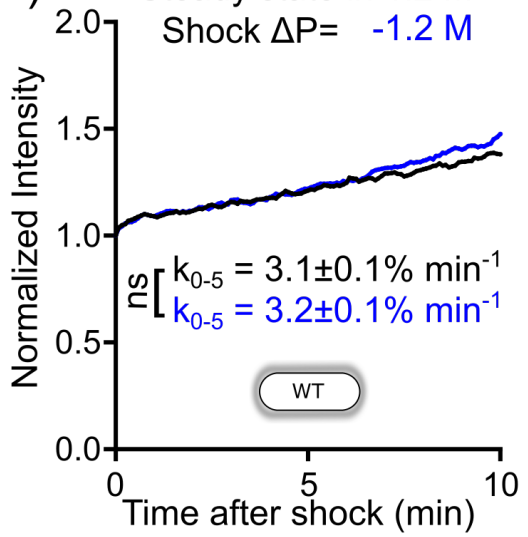

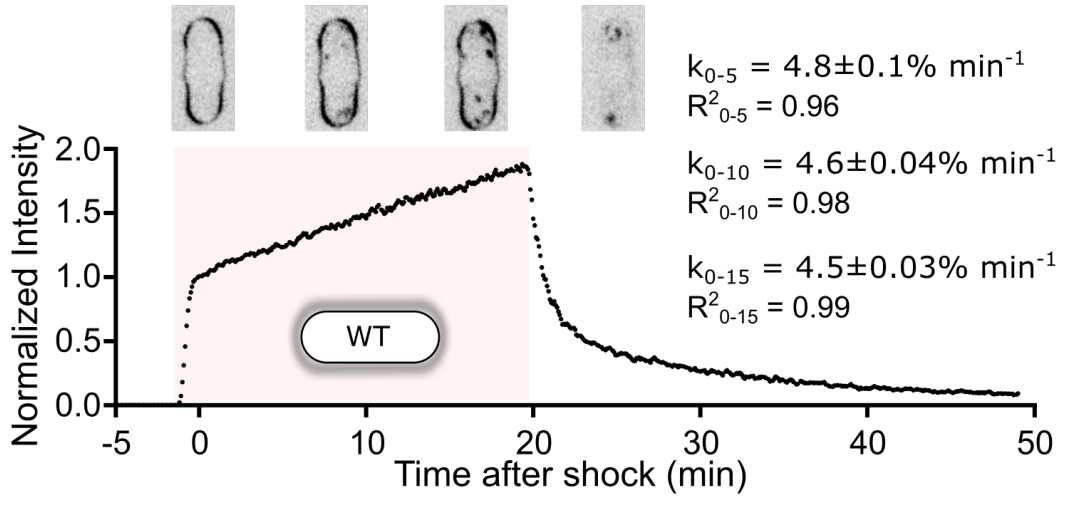

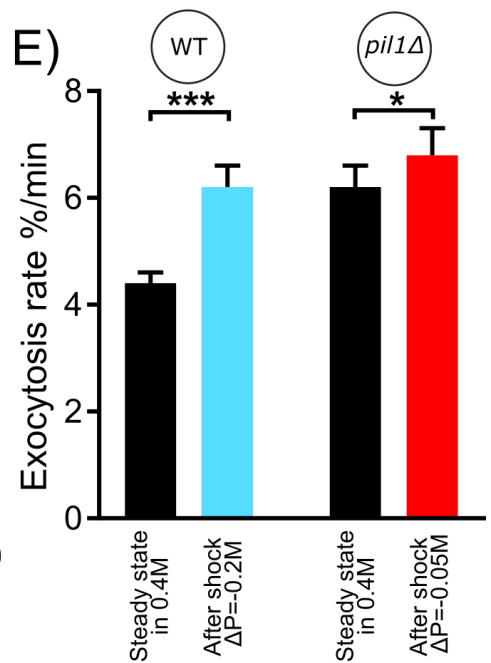

$\mathrm{H})$

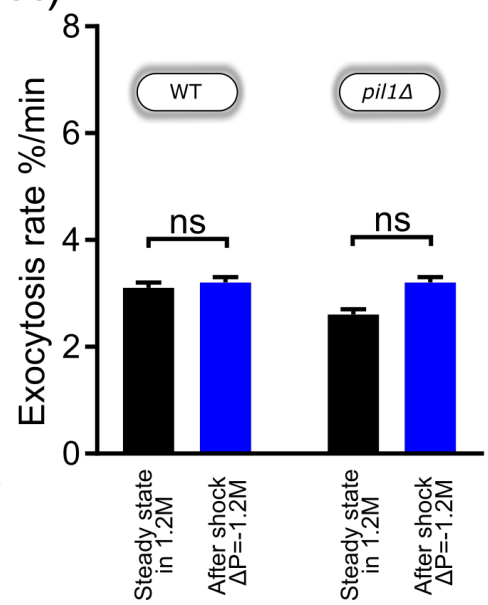

Figure 8: Exocytosis rate increases after an acute change in membrane tension in protoplasts but not in walled cells. A) Rationale of measurement of whole cell exocytosis rate through FM4-64 staining. After FM4-64 is flown in the imaging chamber, the dye rapidly binds to the cell surface in less than a minute. After this initial phase, the whole cell fluorescence increases every time new (unlabeled) internal membrane is exposed to the cell surface by exocytosis. Note that endocytic events do not change the total fluorescence measured. B) Measurement of yeast cell exocytosis rate at steady state in $0 \mathrm{M}$ sorbitol. Cells were stained with $20 \mu \mathrm{M}$ FM4-64 in EMM5S for 20 min before washing with EMM5S. During FM4-64 staining, the fluorescence intensity increases rapidly for 1 min before entering a slow linear phase over at least 
bioRxiv preprint doi: https://doi.org/10.1101/342030; this version posted January 27, 2021. The copyright holder for this preprint (which was not certified by peer review) is the author/funder, who has granted bioRxiv a license to display the preprint in perpetuity. It is made available under

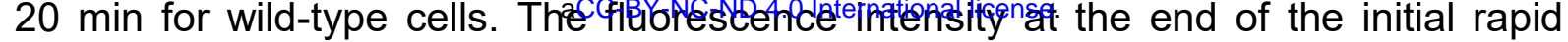
increase phase corresponds to the complete staining of cell surface. It was normalized to 1 , so that the subsequent increase in fluorescence intensity corresponds to a percentage of the plasma membrane surface area. After the dye was removed 20 min later, the decrease in fluorescence intensity suggests that the incorporation of FM4-64 didn't interfere with the vesicle trafficking pathway of the cell. The rate of exocytosis (measured as a percentage of the plasma membrane surface area per minute) is the slope of a linear fit of the measured signal over the first $5 \mathrm{~min}\left(\mathrm{k}_{0-5}\right), 10 \mathrm{~min}\left(\mathrm{k}_{0-10}\right)$ or $15 \mathrm{~min}\left(\mathrm{k}_{0-15}\right)$. Example images of stained cells at different time points are shown in the middle panel (inverted contrast). (C) - $(\mathrm{H})$ Rates of exocytosis at steady state and after hypotonic shocks. C) and D) The exocytic rate of wild-type and pil1 $\Delta$ protoplasts increases after a $\Delta P=-0.2 \mathrm{M}$ (black, before shock, $\mathrm{N}_{\text {cells }}=20$; light blue, after shock, $\mathrm{N}_{\text {cells }}=37 ; 4$ replicates each) and $\Delta \mathrm{P}=-0.05 \mathrm{M}$ (black, before shock, $\mathrm{N}_{\text {cells }}=44$; red, after shock, $\mathrm{N}_{\text {cells }}=60 ; 4$ replicates each) acute hypotonic shocks, respectively. Before time $0 \mathrm{~min}$, all protoplasts were at steady-state in $0.4 \mathrm{M}$ sorbitol. Curves for individual conditions in panels (C) and (D) are plotted in Figure 8 Supplement $1 \mathrm{~A}$ and $B$, respectively. E) Summary of exocytic rates for wild-type and pil1 $1 \Delta$ protoplasts before and after hypotonic shock. F) and G) The exocytic rate of wild-type walled cells is not changed after a $\Delta \mathrm{P}=-1.2 \mathrm{M}$ acute hypotonic shock (black, before shock, $\mathrm{N}_{\text {cells }}=79$; blue, after shock, $\mathrm{N}_{\text {cells }}=68 ; 3$ replicates each). The exocytic rate of pil1 $\Delta$ walled cells does not change significantly in the same conditions (black, before shock, $\mathrm{N}_{\text {cells }}=60$; blue, after shock, $\mathrm{N}_{\text {cells }}=96 ; 3$ replicates each). All walled cells were at steady-state in $1.2 \mathrm{M}$ sorbitol before time $0 \mathrm{~min}$. Curves for individual conditions in panels $(F)$ and $(G)$ are plotted in Figure 8 Supplement $1 C$ and $D$, respectively. H) Summary of exocytic rates for wild-type and pil1 $\Delta$ walled cells before and after hypotonic shock. $(C)-(H)$ Data from at least three independent experiments were pooled together to produce each curve. $p$-values: non-significant (ns), $p>0.05$; one star $\left({ }^{*}\right), p \leq 0.05$; three stars $\left(^{* * *}\right)$, $\mathrm{p} \leq 0.001$. 
bioRxiv preprint doi: https://doi.org/10.1101/342030; this version posted January 27, 2021. The copyright holder for this preprint (which was not certified by peer review) is the author/funder, who has granted bioRxiv a license to display the preprint in perpetuity. It is made available under Steady state in $0.4 \mathrm{M}$ Shock $\Delta \mathrm{P}=$

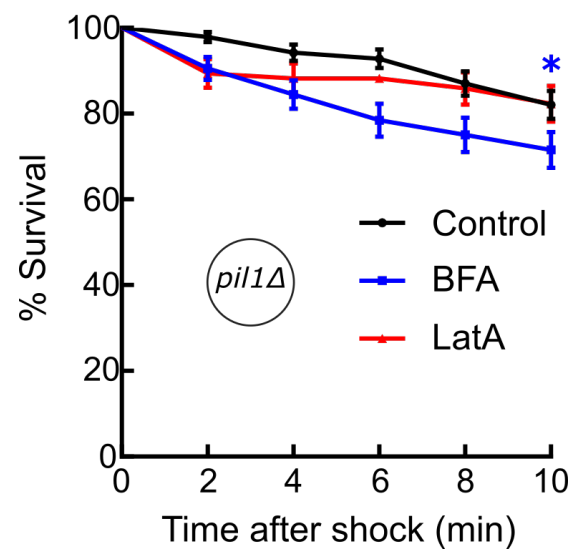

Figure 9: Inhibition of exocytosis but not endocytosis decreased the survival rate of protoplasts under acute hypotonic shock. pil1 $\Delta$ protoplasts initially at steady state in $0.4 \mathrm{M}$ sorbitol (black line; $\mathrm{N}=114$ ), $0.4 \mathrm{M}$ sorbitol plus $2 \mathrm{mM}$ BFA (Blue line; $\mathrm{N}=83$ ), or $0.4 \mathrm{M}$ sorbitol plus $25 \mu \mathrm{M}$ Latrunculin $\mathrm{A}$ (Red line; $\mathrm{N}=70$ ), were submitted to a $\triangle \mathrm{P}=-0.2 \mathrm{M}$ hypotonic shock ( $\mathrm{t}=0 \mathrm{~min}$ ), and their survival rates were compared over time. BFA or Latrunculin A were included in the respective shock solution. Only BFA treatment led to a significant decreased survival rate of protoplasts compared with the control group. Data are pooled from two independent experiments and plotted as Kaplan-Meier survival curves. Error bars: standard error of the mean by the Greenwood formula. One star $\left(^{*}\right), p \leq 0.05$, logrank test. Typical fields of view for each condition are shown in Figure 9 Supplement 1. 
bioRxiv preprint doi: https://doi.org/10.1101/342030; this version posted January 27, 2021. The copyright holder for this preprint (which was not certified by peer review) is the author/funder, who has granted bioRxiv a license to display the preprint in perpetuity. It is made available under aCC-BY-NC-ND 4.0 International license.

A) $\boldsymbol{U}$ Endocytic pit with actin patch

(s) Pil1p

Exocytic vesicle

Endocytic vesicle
EXXXXXX Cell wall

$\rightarrow$ Membrane tension

$\Delta$ Exocytosis

$\nabla$ Endocytosis

\section{Isotonic solution}
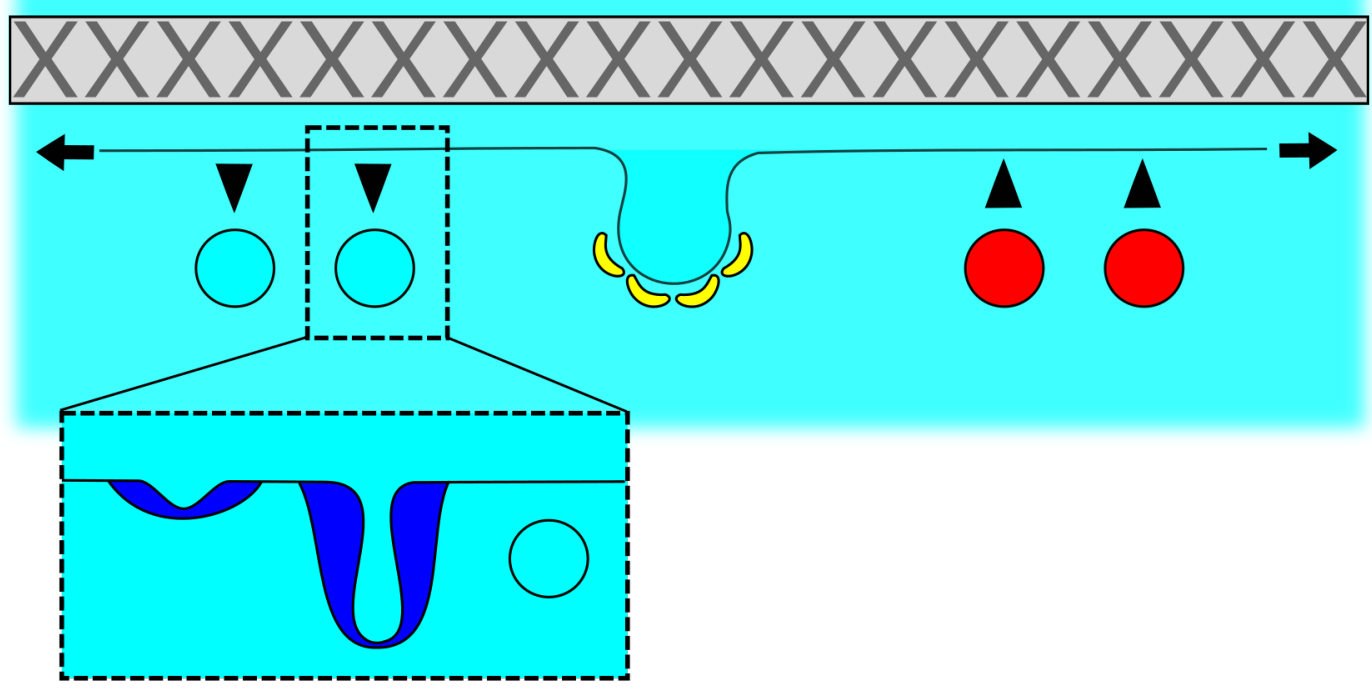

B)

After acute hypotonic shock

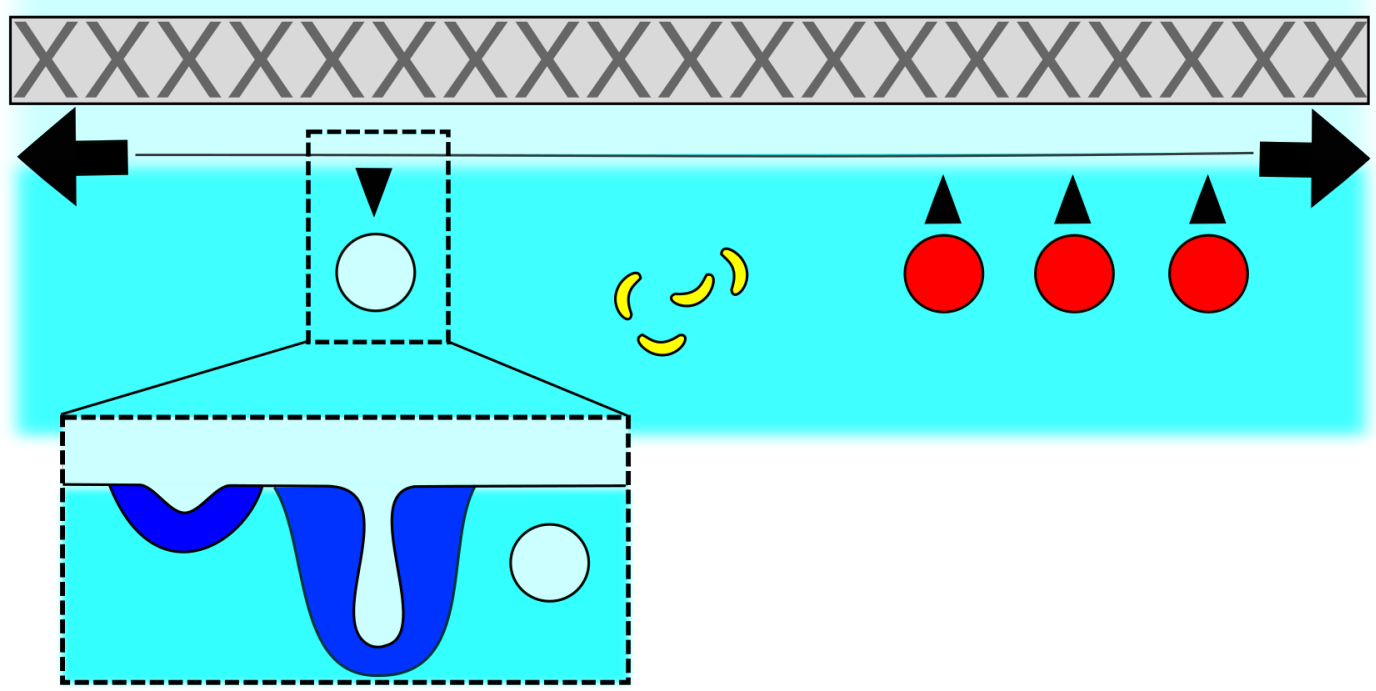


bioRxiv preprint doi: https://doi.org/10.1101/342030; this version posted January 27, 2021. The copyright holder for this preprint (which was not certified by peer review) is the author/funder, who has granted bioRxiv a license to display the preprint in perpetuity. It is made available under aCC-BY-NC-ND 4.0 International license.

Figure 10: Schematic of the adaptation of fission yeast endocytosis, exocytosis and eisosome after acute hypotonic shock-induced increase in membrane tension. A) In an isotonic solution, endocytosis and exocytosis rates are largely balanced, and proteins including Pil1p are assembled at the plasma membrane to form eisosomes. Actin is recruited to endocytic sites to provide the forces needed to reshape the membrane under normal membrane tension. When present, cell wall makes fission yeast cell resistant to significant changes in the osmolarity of extracellular solution. B) Acute hypotonic shock results in an increase of membrane tension, which leads to a decrease of endocytosis rate, an increase in exocytosis rate, and a rapid disassembly of eisosomes, within $\sim 2$ minutes. The proteins of the actin machinery are recruited in larger amount to endocytic sites to provide larger forces for successful endocytosis under increased membrane tension. Failure of adaptation to the increase in membrane tension leads to membrane rupture and cell death in both protoplasts and walled cells. 
bioRxiv preprint doi: https://doi.org/10.1101/342030; this version posted January 27, 2021. The copyright holder for this preprint (which was not certified by peer review) is the author/funder, who has granted bioRxiv a license to display the preprint in perpetuity. It is made available under aCC-BY-NC-ND 4.0 International license.

\section{Supplemental figures}


bioRxiv preprint doi: https://doi.org/10.1101/342030; this version posted January 27, 2021. The copyright holder for this preprint (which was not certified by peer review) is the author/funder, who has granted bioRxiv a license to display the preprint in perpetuity. It is made available under
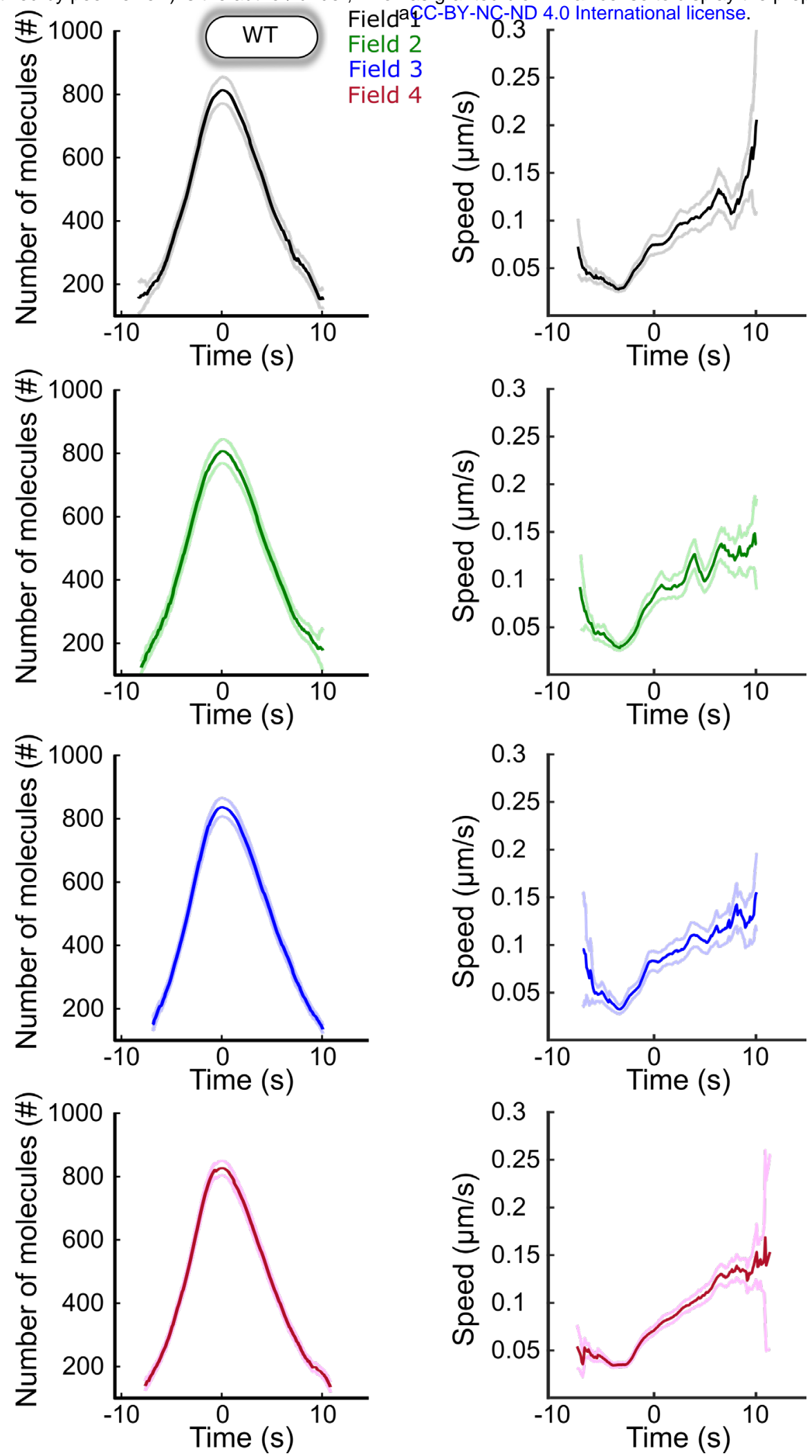

Figure 1 Supplement 1: Separate plots for the data from each field of view in panels $1 \mathrm{~F}$ and 1G. Each curve with a dark color represents the average of several endocytic events from a different field of view of the same sample $(N \geq 64)$, and the light colors are the $95 \%$ confidence intervals. For each average curve, the peak value 
bioRxiv preprint doi: https://doi.org/10.1101/342030; this version posted January 27, 2021. The copyright holder for this preprint (which was not certified by peer review) is the author/funder, who has granted bioRxiv a license to display the preprint in perpetuity. It is made available under

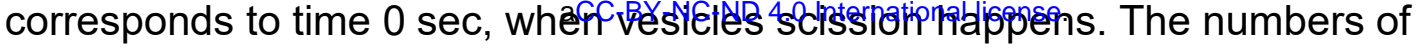
endocytic events used in each curve are given in Supplemental Table 2. 
bioRxiv preprint doi: https://doi.org/10.1101/342030; this version posted January 27, 2021. The copyright holder for this preprint (which was not certified by peer review) is the author/funder, who has granted bioRxiv a license to display the preprint in perpetuity. It is made available under
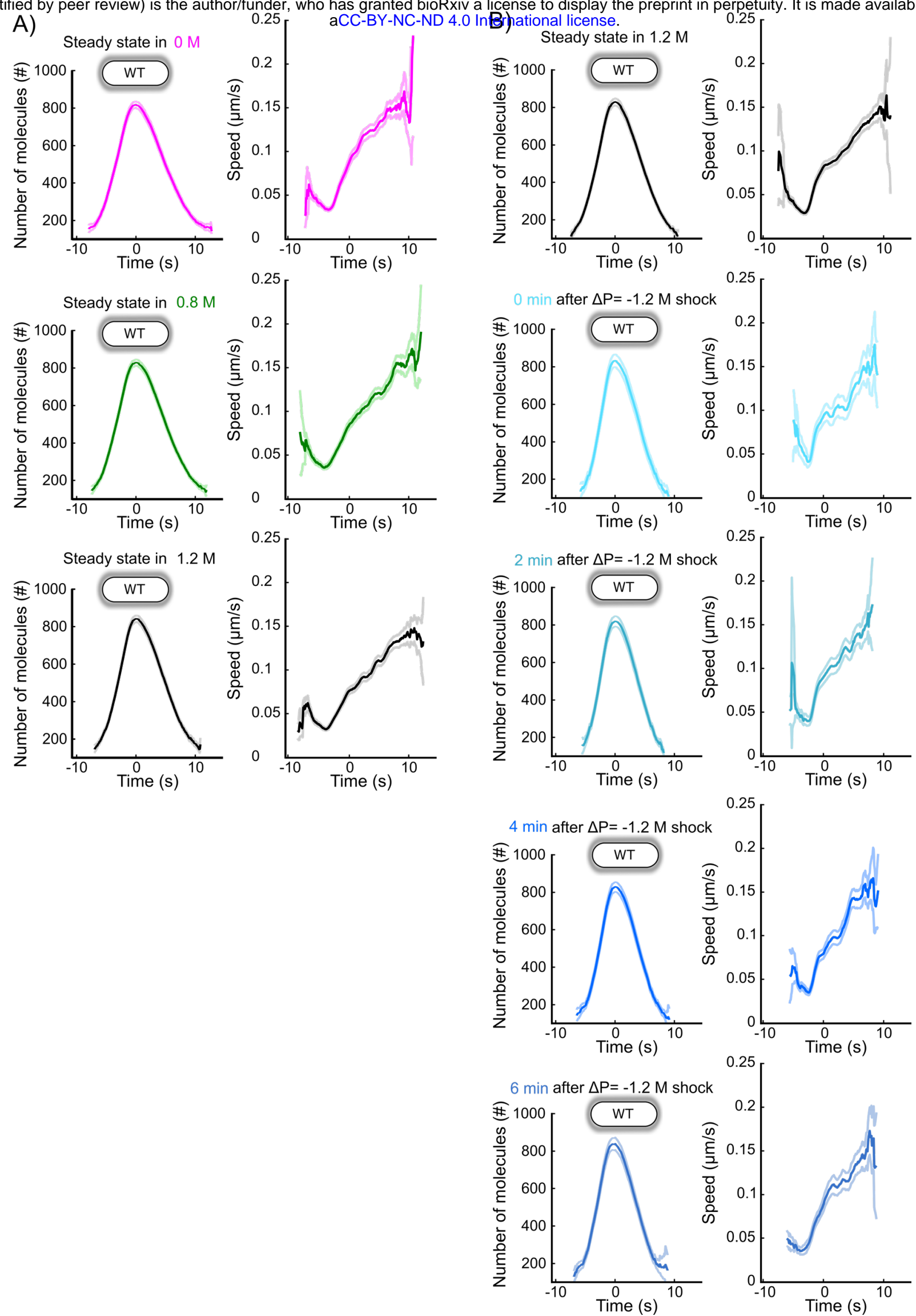

Figure 2 Supplement 1: Separate plots for each condition in Figures 2B $(A)$ and $2 F$ (B). A) Number of molecules (left panel) and speed (right panel) of Fim1p-mEGFP in wild-type walled cells at steady state in media supplemented with different sorbitol 
bioRxiv preprint doi: https://doi.org/10.1101/342030; this version posted January 27, 2021. The copyright holder for this preprint (which was not certified by peer review) is the author/funder, who has granted bioRxiv a license to display the preprint in perpetuity. It is made available under

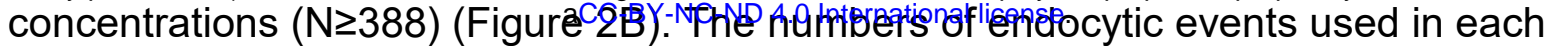
curve are given in Supplemental Table 3. E) Number of molecules (left panel) and speed (right panel) of Fim1p-mEGFP for wild-type walled cells initially at steady state in 1.2 $\mathrm{M}$ sorbitol and after an acute osmotic shock of $\Delta \mathrm{P}=-1.2 \mathrm{M}$. Black: steady state in $1.2 \mathrm{M}$ sorbitol; light to dark blue (from top to bottom rows): $0 \mathrm{~min}, 2 \mathrm{~min}, 4 \mathrm{~min}$, and 6 min after the acute hypotonic shock $(\mathrm{N} \geq 103)$ (Figure $2 \mathrm{~F})$. The numbers of endocytic events used in each curve are given in Supplemental Table 4. (A) and (B): dark colors: average; light colors: average $+/-95 \%$ confidence interval. 
bioRxiv preprint doi: https://doi.org/10.1101/342030; this version posted January 27, 2021. The copyright holder for this preprint (which was not certified by peer review) is the author/funder, who has granted bioRxiv a license to display the preprint in perpetuity. It is made available under aCC-BY-NC-ND 4.0 International license.
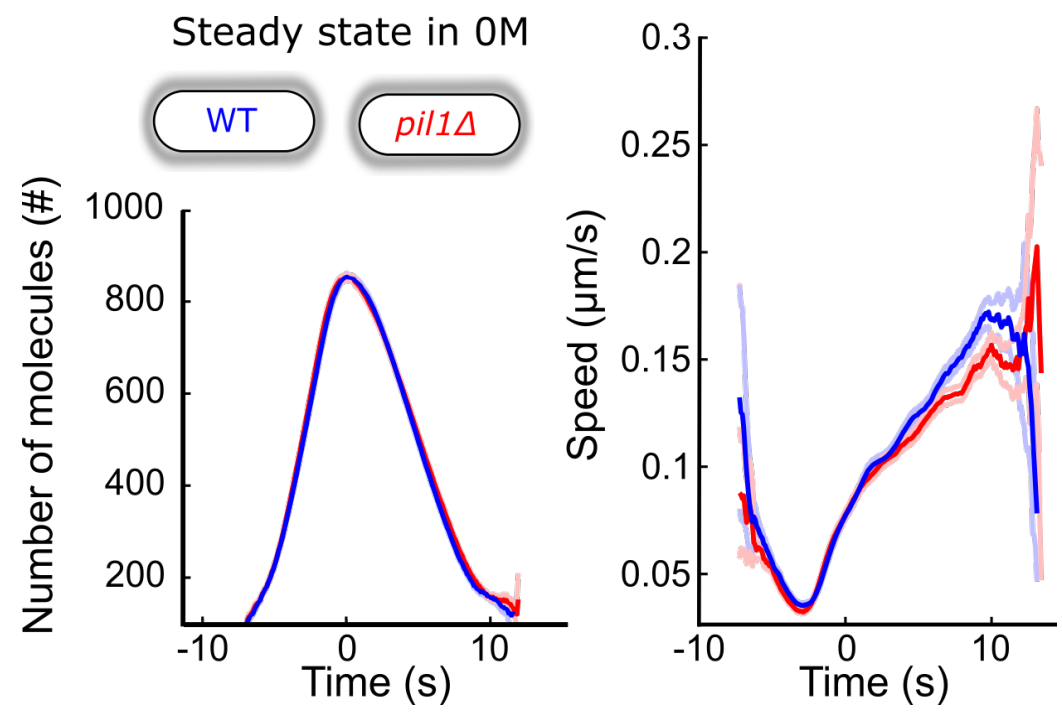

Figure 3 Supplement 1: The number of molecules (left panel) and speed (right panel) of Fim1p-mEGFP at CME sites in wild-type (blue, $\mathrm{N}=1773$ ) and pil1 $(\mathrm{red}, \mathrm{N}=1884$ ) walled cells at steady state in EMM5S without sorbitol are identical (same data as Figures $2 \mathrm{~B}$ and $3 \mathrm{~B}$ ). Dark colors: average, light colors: average $+/-95 \%$ confidence interval. 
bioRxiv preprint doi: https://doi.org/10.1101/342030; this version posted January 27, 2021. The copyright holder for this preprint (which was not certified by peer review) is the author/funder, who has granted bioRxiv a license to display the preprint in perpetuity. It is made available under

A)

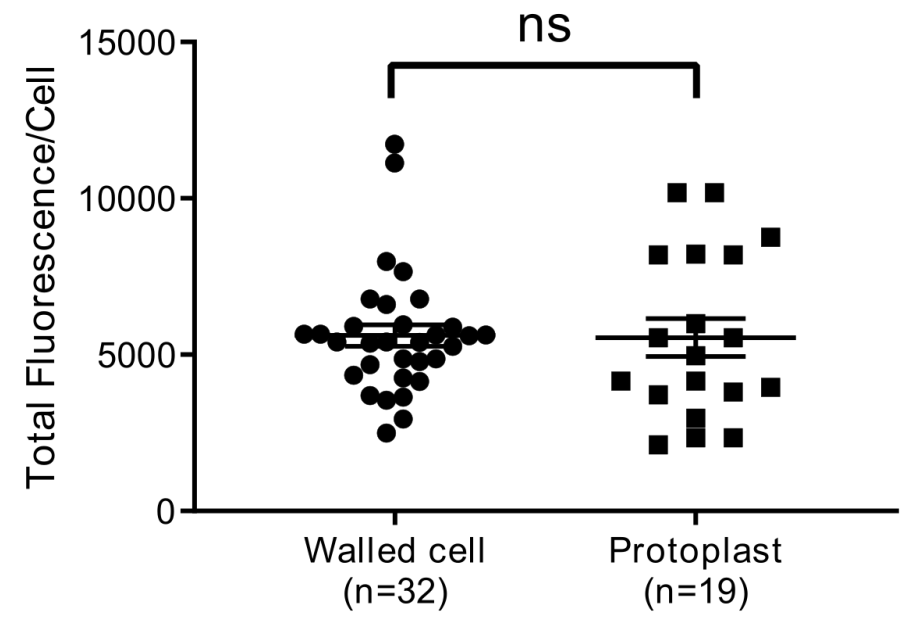

B)

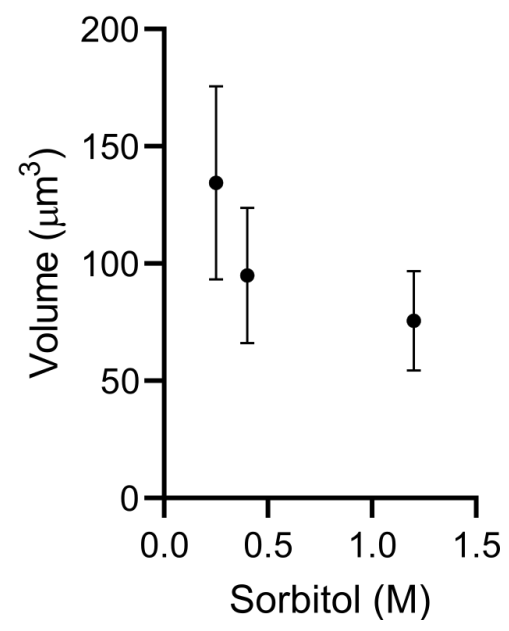

Figure 4 Supplemental 1: A) The total amount of Pil1-mEGFP in walled cells and protoplasts are not significantly different (Mann-Whitney test, $P=0.65$ ). Bars: mean and standard error of the mean. B) Protoplasts volume at steady state in $0.25 \mathrm{M}$ $(\mathrm{N}=26), 0.4 \mathrm{M}(\mathrm{N}=34)$ and $1.2 \mathrm{M}(\mathrm{N}=39)$ sorbitol (same cells were used as in Figure 4C). Error bars: standard deviations. 
bioRxiv preprint doi: https://doi.org/10.1101/342030; this version posted January 27, 2021. The copyright holder for this preprint (which was not certified by peer review) is the author/funder, who has granted bioRxiv a license to display the preprint in perpetuity. It is made available under A) $1400[\quad$ aCC-BY-NC-ND 4.0 BHetritational license.
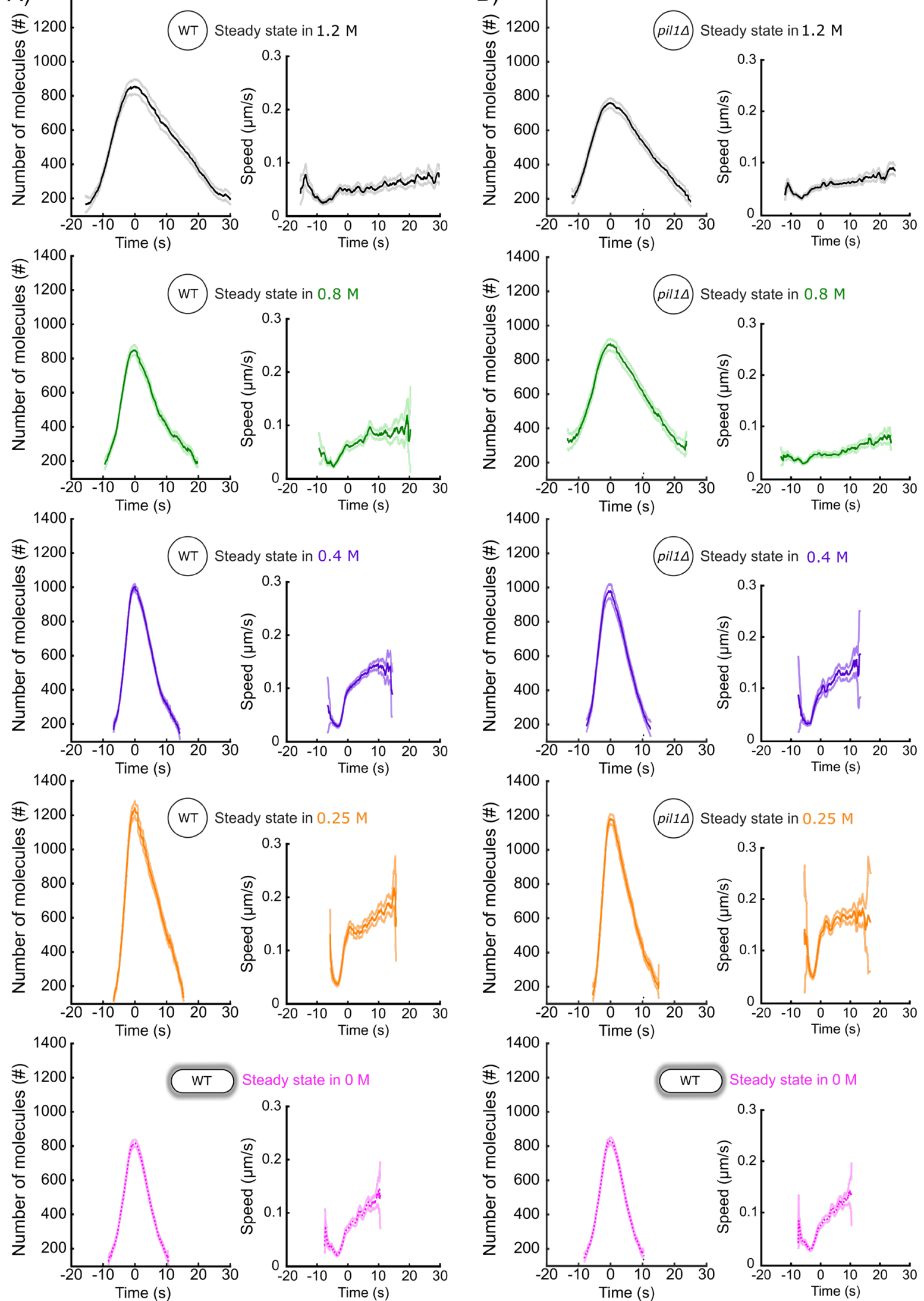

Figure 4 Supplemental 2: Separate plots for each condition in Figures $4 \mathrm{~F}(\mathrm{~A})$ and $4 G$ (B). A) and B) Number of molecules (left panels) and speed (right panels) of Fim1p-mEGFP for wild-type $(\mathrm{A})$ and pil1 $\triangle(\mathrm{B})$ protoplasts at steady state in different sorbitol concentrations. Orange: $0.25 \mathrm{M}$; purple: 0; green: $0.8 \mathrm{M}$; black: $1.2 \mathrm{M}$. Dark 
bioRxiv preprint doi: https://doi.org/10.1101/342030; this version posted January 27, 2021. The copyright holder for this preprint (which was not certified by peer review) is the author/funder, who has granted bioRxiv a license to display the preprint in perpetuity. It is made available under

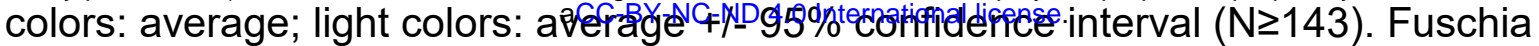
dotted curves: wild-type walled cells at steady state in $0 \mathrm{M}$ sorbitol (same as Figure 3B). The numbers of endocytic events used in each curve are given in Supplemental Table 7 . 
bioRxiv preprint doi: https://doi.org/10.1101/342030; this version posted January 27, 2021. The copyright holder for this preprint (which was not certified by peer review) is the author/funder, who has granted bioRxiv a license to display the preprint in perpetuity. It is made available under

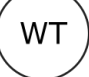

$$
\Delta \mathrm{P}=-0.05 \mathrm{M}
$$
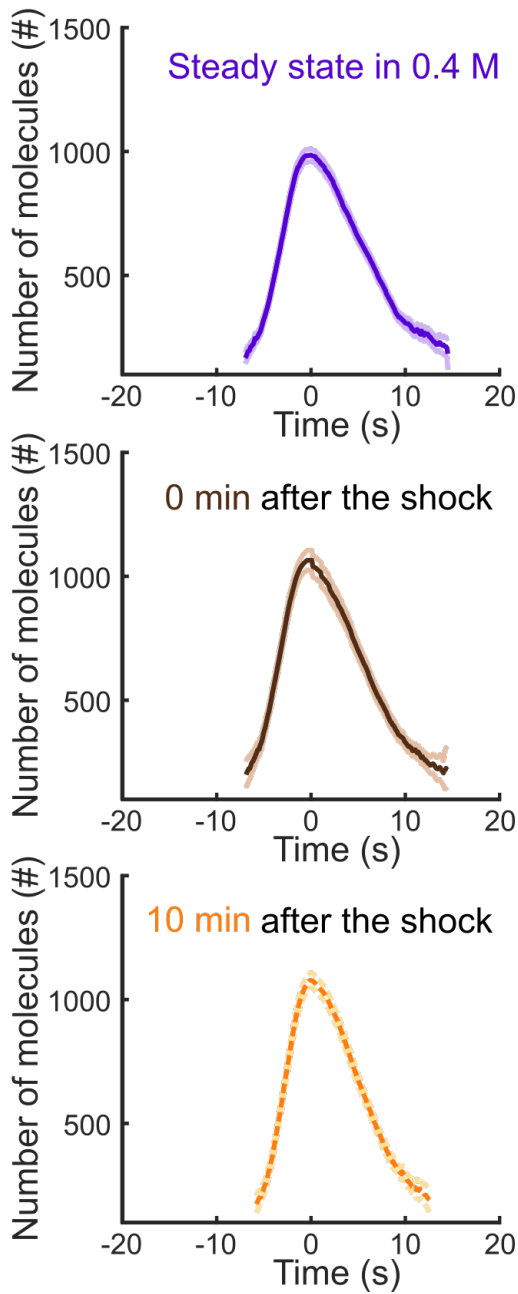

$\Delta \mathrm{P}=-0.1 \mathrm{M}$
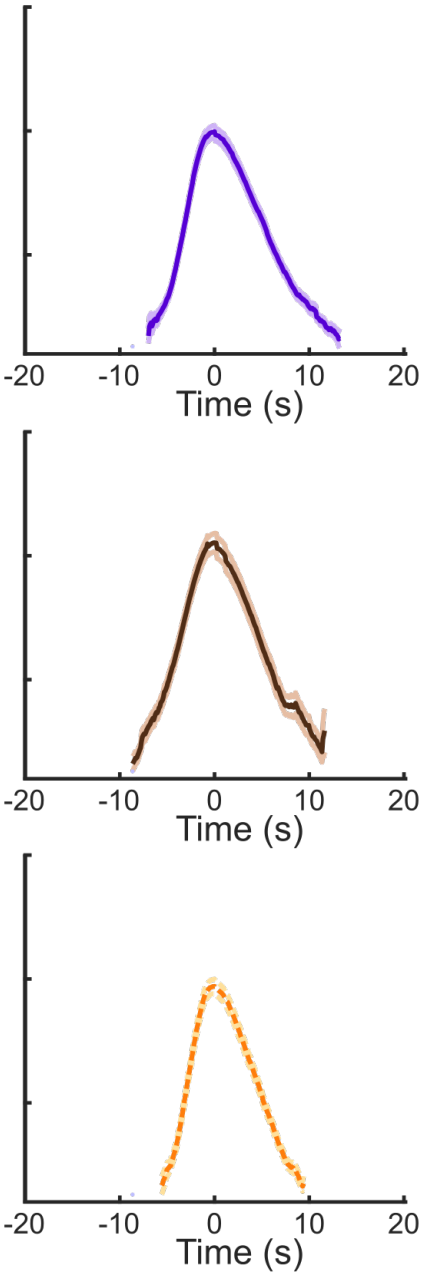

$\Delta \mathrm{P}=-0.2 \mathrm{M}$
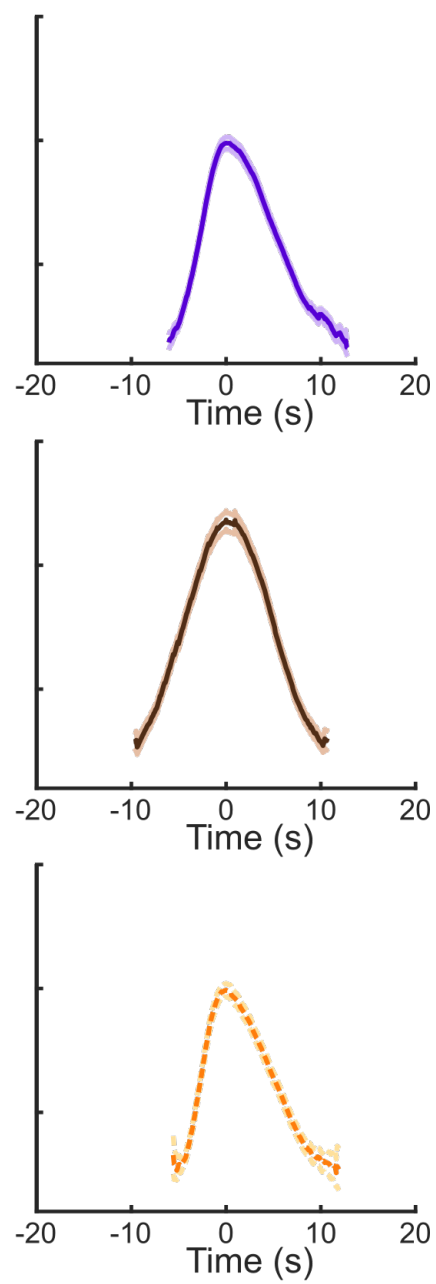

Figure 5 Supplement 1: Separate plots for each condition shown in Figure 5C. Number of Fim1p-mEGFP molecules in wild-type protoplasts at steady-state in $0.4 \mathrm{M}$ sorbitol (purple), 0 min (brown) and 10 min (orange) after an hypotonic shock of $\Delta \mathrm{P}=$ $0.05 \mathrm{M}$ (left panels), $\Delta P=-0.1 \mathrm{M}$ (middle panels) and $\Delta P=-0.2 \mathrm{M}$ (right panels), $\mathrm{N} \geq 95$. The speeds of Fim1p-mEGFP for each condition are shown in Figure 5 Supplements 3 . The numbers of endocytic events used in each curve are given in Supplemental Table 8. Dark colors: average, light colors: average $+/-95 \%$ confidence interval. 
bioRxiv preprint doi: https://doi.org/10.1101/342030; this version posted January 27, 2021. The copyright holder for this preprint (which was not certified by peer review) is the author/funder, who has granted bioRxiv a license to display the preprint in perpetuity. It is made available under

pil1

$\Delta \mathrm{P}=-0.05 \mathrm{M}$

$\Delta \mathrm{P}=-0.1 \mathrm{M}$

$\Delta \mathrm{P}=-0.2 \mathrm{M}$
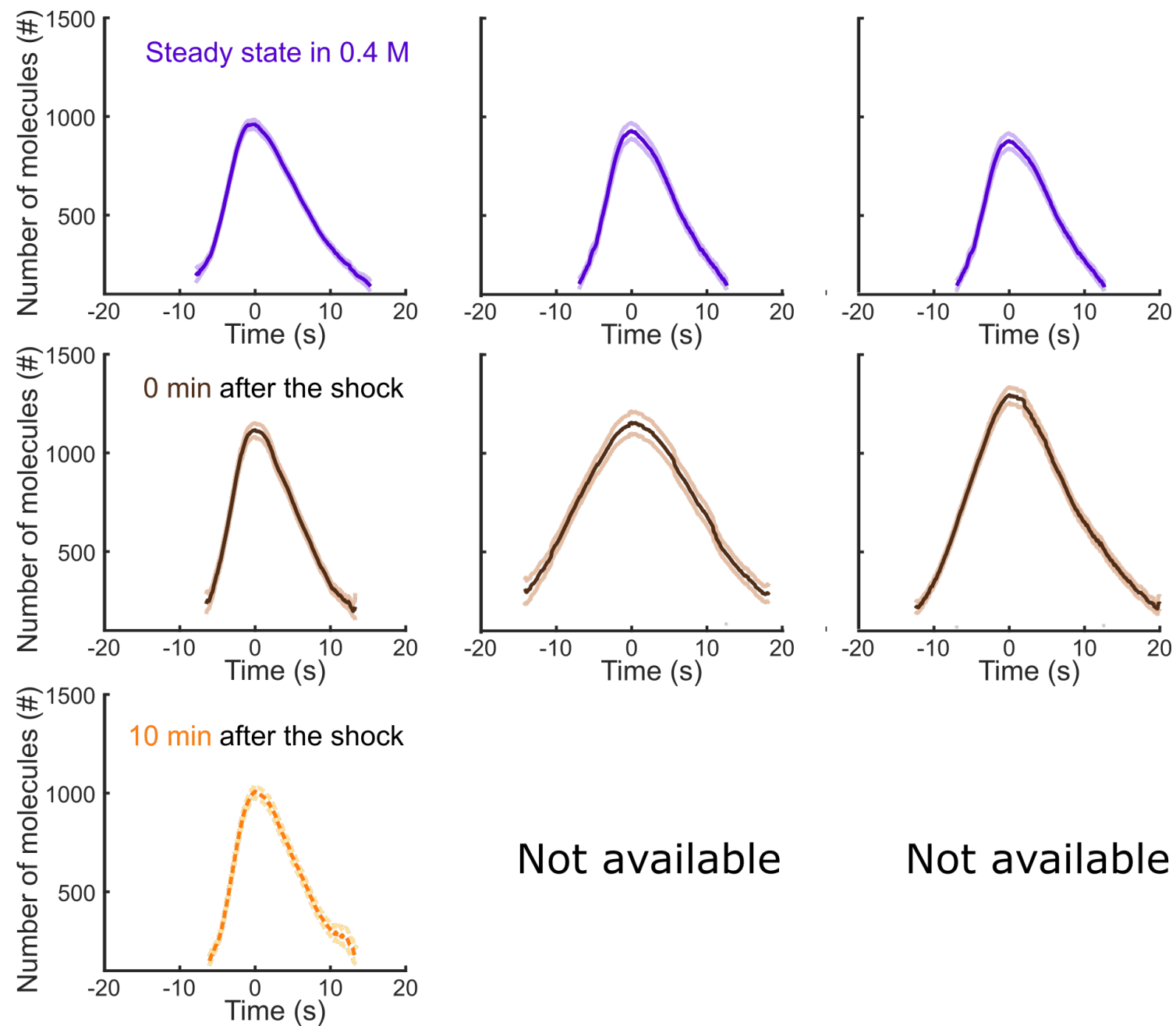

Not available

Not available

Figure 5 Supplement 2: Separate plots for each condition shown in Figure 5F. Number of Fim1p-mEGFP molecules in pil1 $\Delta$ protoplasts at steady-state in $0.4 \mathrm{M}$ sorbitol (purple), 0 min (brown) and $10 \mathrm{~min}$ (orange) after an hypotonic shock of $\triangle P=$ $0.05 \mathrm{M}$ (left panels), $\Delta \mathrm{P}=-0.1 \mathrm{M}$ (middle panels) and $\Delta \mathrm{P}=-0.2 \mathrm{M}$ (right panels), $\mathrm{N} \geq 95$. The speeds of Fim1p-mEGFP for each condition are shown in Figure 5 Supplements 4. The numbers of endocytic events used in each curve are given in Supplemental Table 8 . Note that the large majority of pil1 $\Delta$ protoplasts were too damaged or dead 2 minutes after hypotonic shocks larger than or equal to $\Delta \mathrm{P}=-0.1 \mathrm{M}$ to allow us to track enough endocytic events and produce a curve (Figures $6 \mathrm{~B}$ and C, Figure 6 Supplement 1 ). Dark colors: average, light colors: average $+/-95 \%$ confidence interval. 
bioRxiv preprint doi: https://doi.org/10.1101/342030; this version posted January 27, 2021. The copyright holder for this preprint (which was not certified by peer review) is the author/funder, who has granted bioRxiv a license to display the preprint in perpetuity. It is made available under

A)

(WT $\Delta \mathrm{P}=-0.05 \mathrm{M}$

Steady state at $0.4 \mathrm{M}$

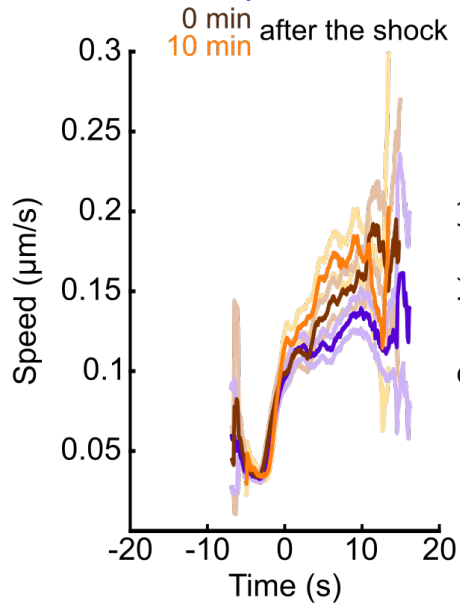

aCC-BY-NC-ND 4.0 International license.

$\Delta \mathrm{P}=-0.1 \mathrm{M}$

$\Delta \mathrm{P}=-0.2 \mathrm{M}$
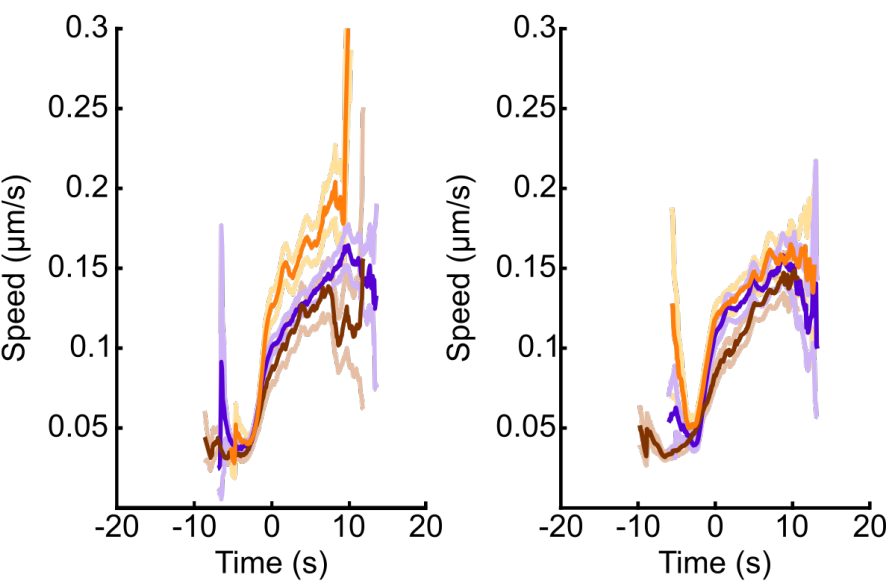

B)
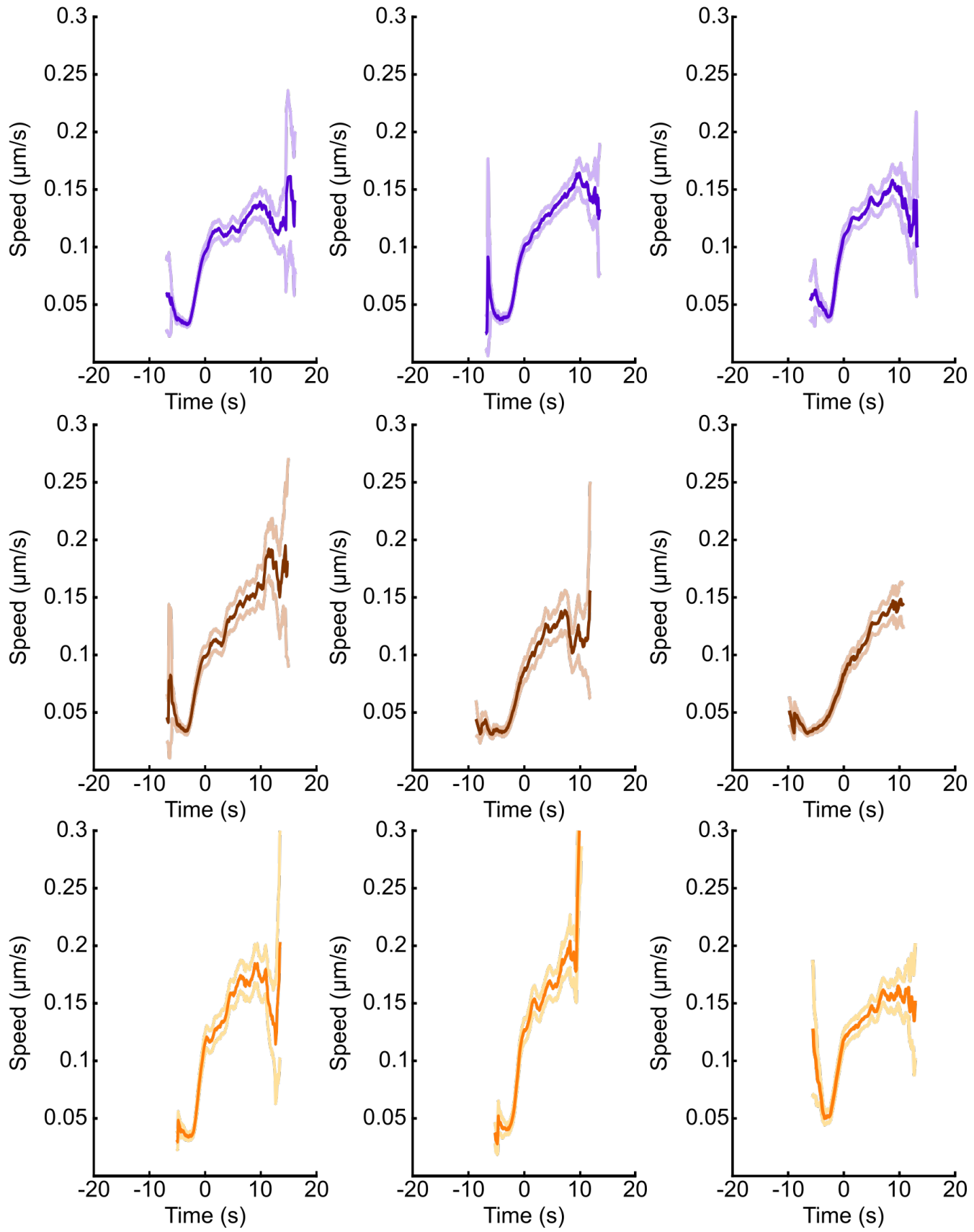
bioRxiv preprint doi: https://doi.org/10.1101/342030; this version posted January 27, 2021. The copyright holder for this preprint (which was not certified by peer review) is the author/funder, who has granted bioRxiv a license to display the preprint in perpetuity. It is made available under

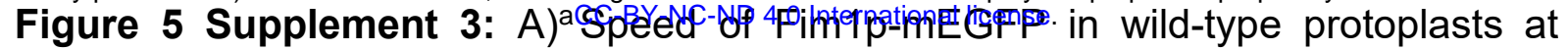
steady-state in $0.4 \mathrm{M}$ sorbitol (purple), $0 \mathrm{~min}$ (brown) and $10 \mathrm{~min}$ (orange) after an hypotonic shock of $\Delta P=-0.05 \mathrm{M}$ (left panels), $\Delta \mathrm{P}=-0.1 \mathrm{M}$ (middle panels) and $\Delta \mathrm{P}=-0.2$ $M$ (right panels). B) Separate plots for each condition shown in panel A. (A and B) The same endocytic events as the ones used in Figure $5 \mathrm{C}$ have been used to generate these plots. The numbers of endocytic events used in each curve are given in Supplemental Table 8. Dark colors: average, light colors: average +/- 95\% confidence interval. 
bioRxiv preprint doi: https://doi.org/10.1101/342030; this version posted January 27, 2021. The copyright holder for this preprint (which was not certified by peer review) is the author/funder, who has granted bioRxiv a license to display the preprint in perpetuity. It is made available under

A)

pil1 $\Delta \mathrm{P}=-0.05 \mathrm{M}$

$\Delta \mathrm{P}=-0.1 \mathrm{M}$

$\Delta \mathrm{P}=-0.2 \mathrm{M}$
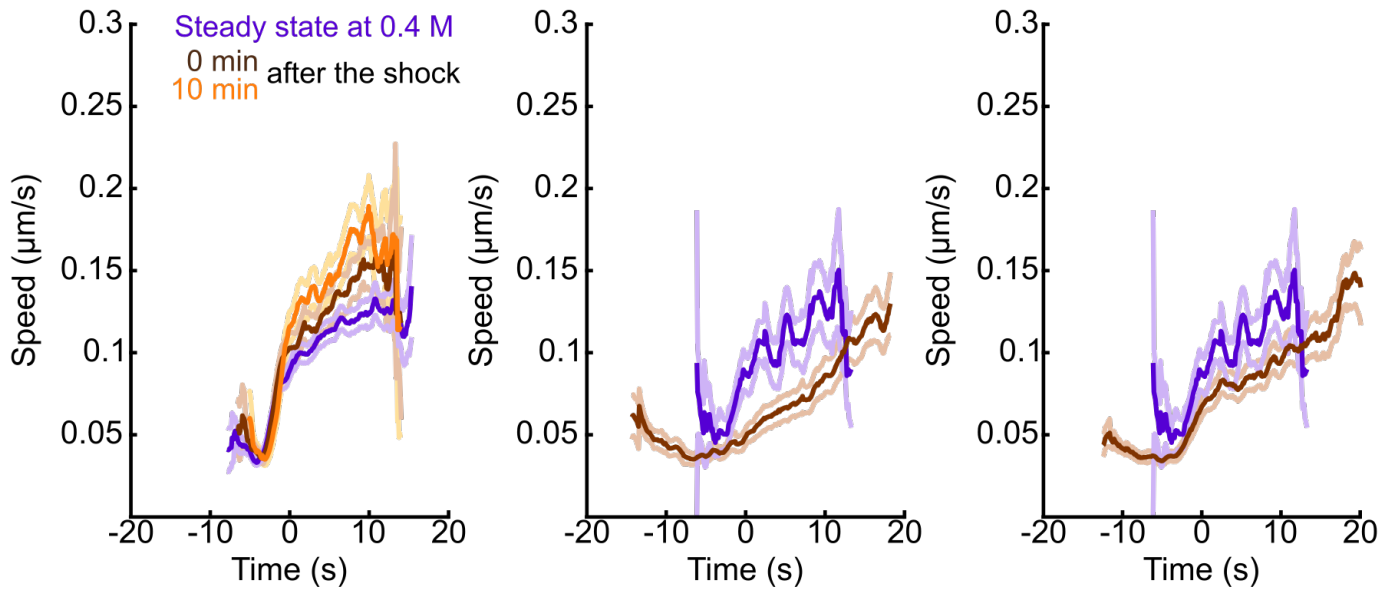

B)
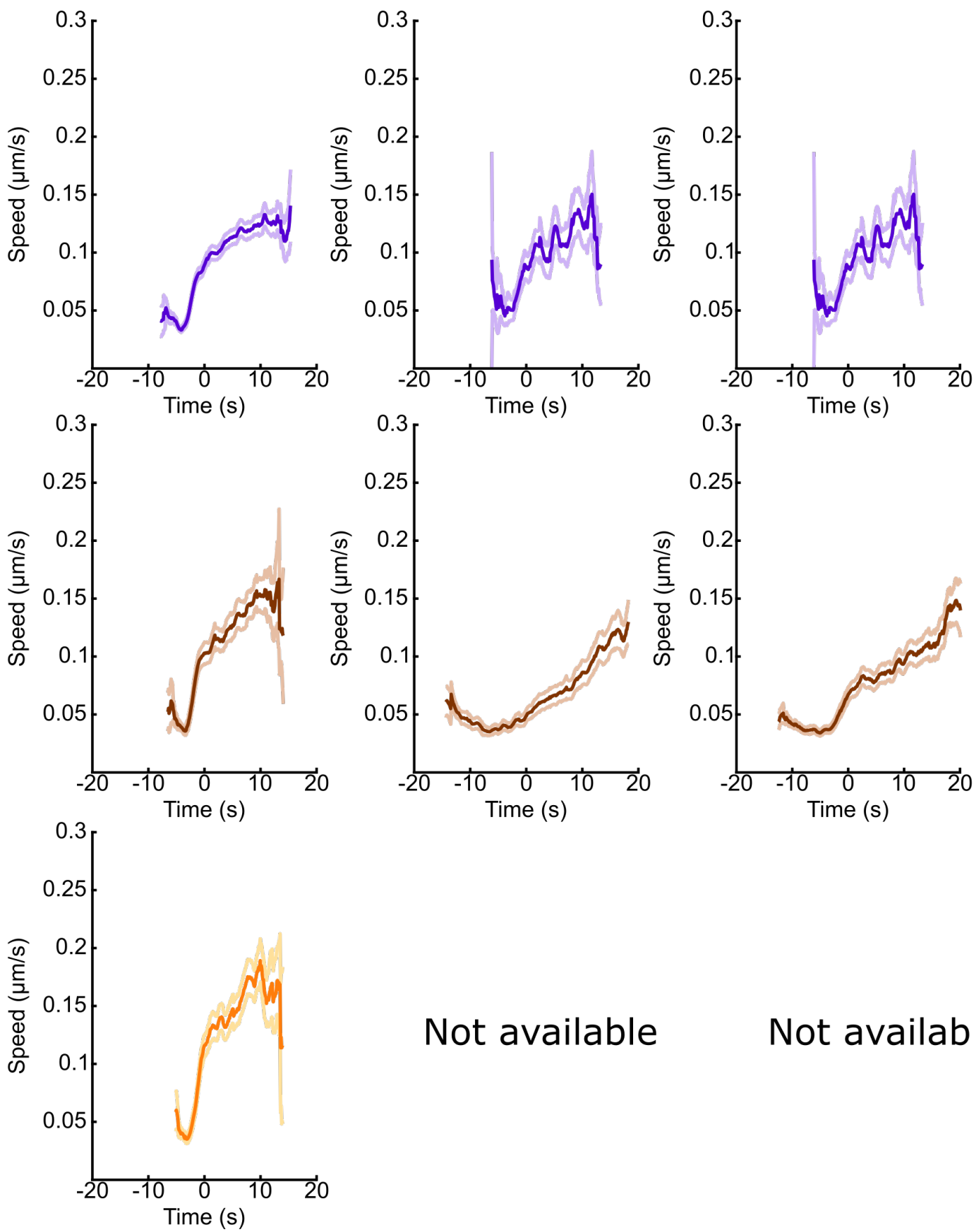

Not available

Not available 
bioRxiv preprint doi: https://doi.org/10.1101/342030; this version posted January 27, 2021. The copyright holder for this preprint (which was not certified by peer review) is the author/funder, who has granted bioRxiv a license to display the preprint in perpetuity. It is made available under

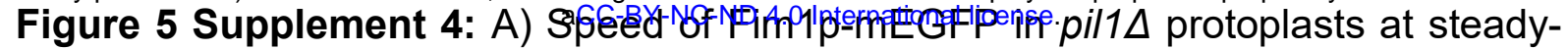
state in $0.4 \mathrm{M}$ sorbitol (purple), 0 min (brown) and $10 \mathrm{~min}$ (orange) after an hypotonic shock of $\Delta P=-0.05 \mathrm{M}$ (left panels), $\Delta \mathrm{P}=-0.1 \mathrm{M}$ (middle panels) and $\Delta \mathrm{P}=-0.2 \mathrm{M}$ (right panels). B) Separate plots for each condition shown in panel $A$. (A and B) The same endocytic events as the ones used in Figure 5F have been used to generate these plots. The numbers of endocytic events used in each curve are given in Supplemental Table 8. Dark colors: average, light colors: average +/- 95\% confidence interval. 
bioRxiv preprint doi: https://doi.org/10.1101/342030; this version posted January 27, 2021. The copyright holder for this preprint (which was not certified by peer review) is the author/funder, who has granted bioRxiv a license to display the preprint in perpetuity. It is made available under

A)

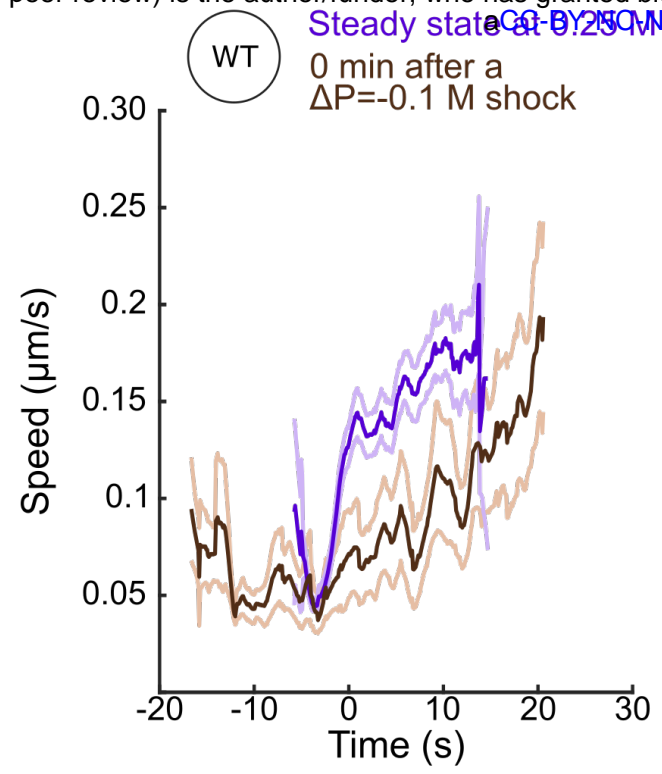

C)

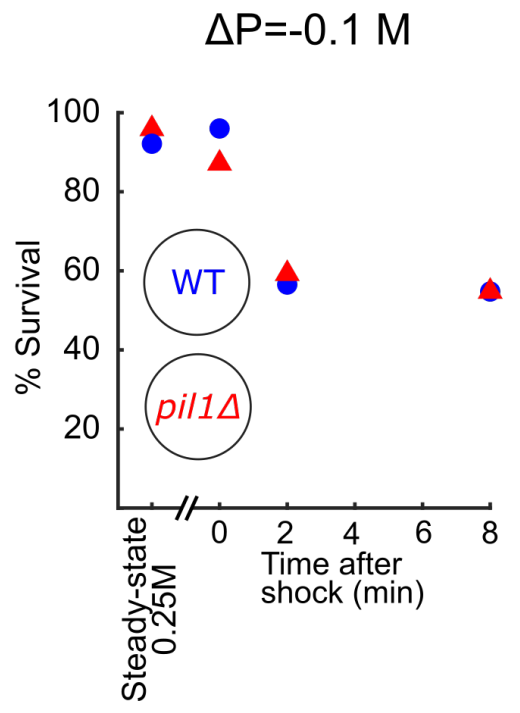

B)

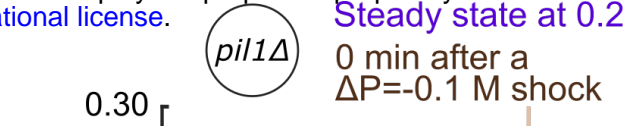

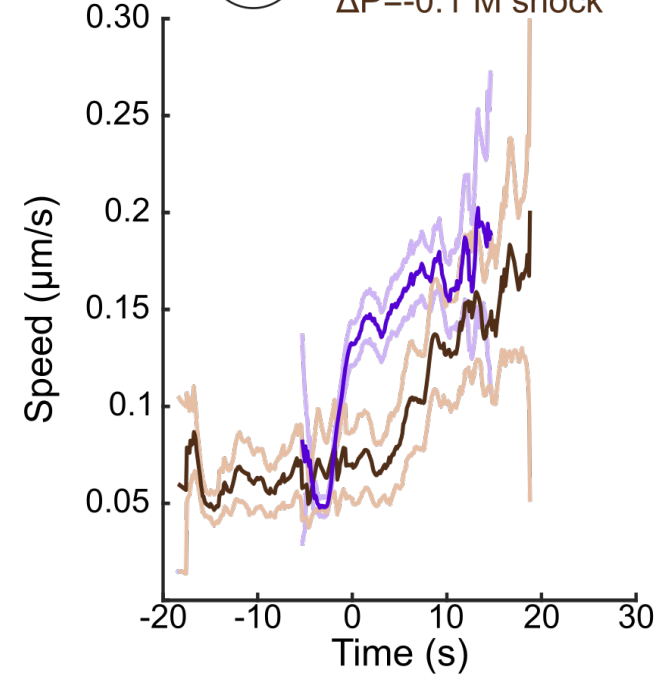


bioRxiv preprint doi: https://doi.org/10.1101/342030; this version posted January 27, 2021. The copyright holder for this preprint (which was not certified by peer review) is the author/funder, who has granted bioRxiv a license to display the preprint in perpetuity. It is made available under

A)

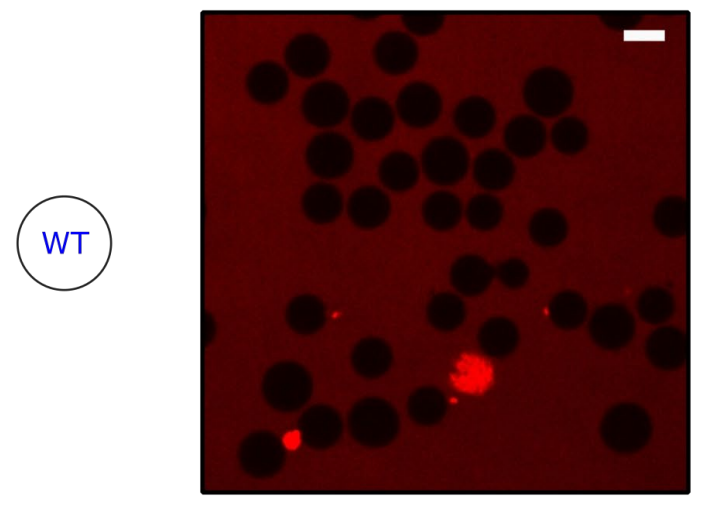

B)

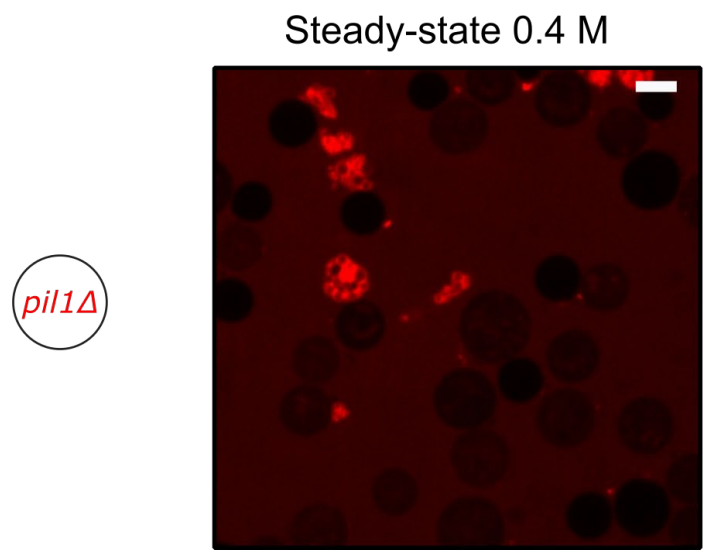

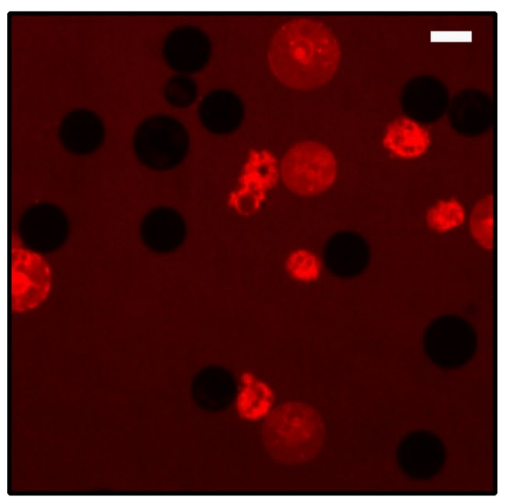

8 minutes after a $\triangle P=-0.1 \mathrm{M}$ shock

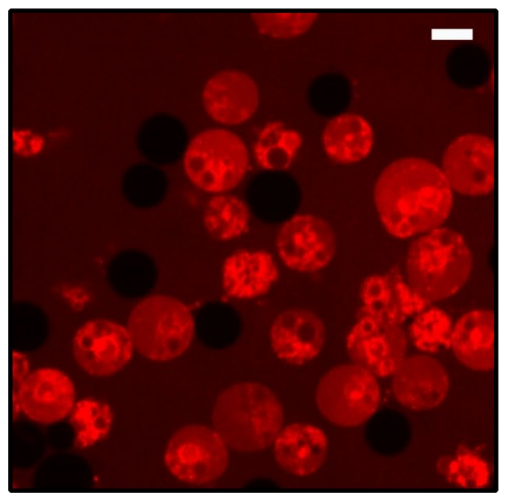

Figure 6 Supplement 1: A) and B) Typical fields of view of wild-type (A) and pil1 $\Delta$ (B) protoplasts at steady state in $0.4 \mathrm{M}$ sorbitol (left panel) and 8 minutes (right panel) after a $\triangle \mathrm{P}=-0.1 \mathrm{M}$ hypotonic shock. Cells are considered alive if they do not contain any red fluorescence from the sulforhodamin B dye. Scale bar: $5 \mu \mathrm{m}$. 
bioRxiv preprint doi: https://doi.org/10.1101/342030; this version posted January 27, 2021. The copyright holder for this preprint (which was not certified by peer review) is the author/funder, who has granted bioRxiv a license to display the preprint in perpetuity. It is made available under

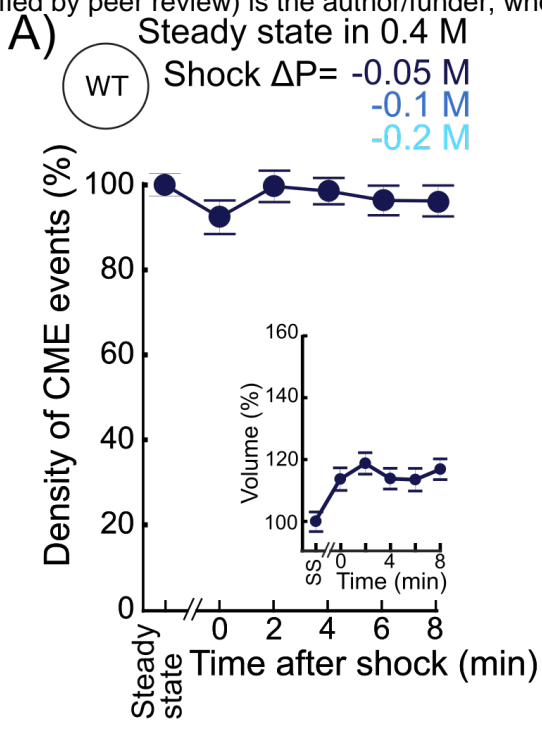
aCC-BY-NC-ND 4.0 International license.
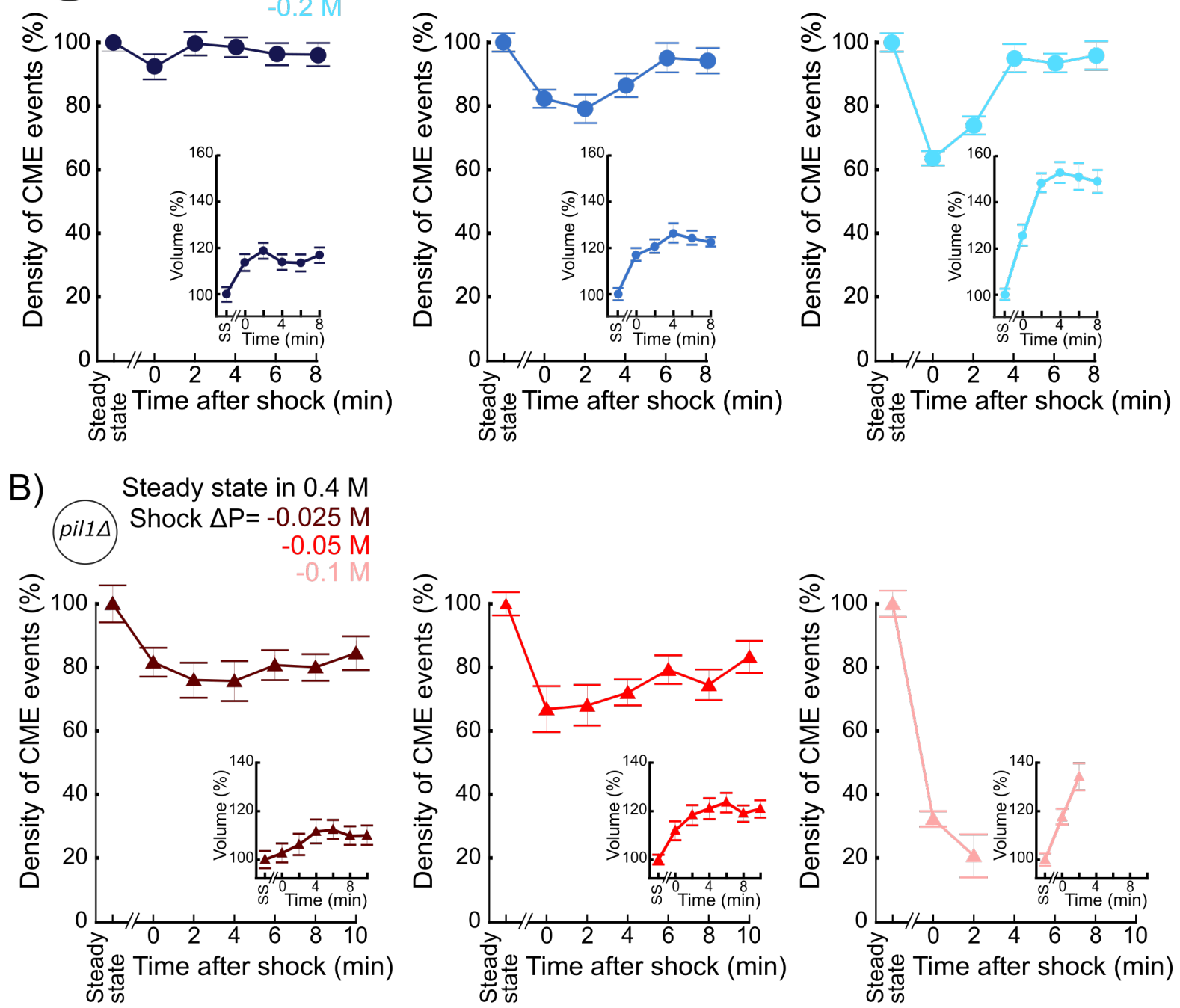

Figure 7 - Supplement 1: Separate plots for each condition shown in Figure 7A and B. A) Temporal evolution of density of endocytic events (average number of endocytic events at a given time in a cell divided by the cell length) in wild-type protoplasts initially at steady state in $0.4 \mathrm{M}$ sorbitol and after an acute hypotonic shock of $\triangle P=-0.05 \mathrm{M}$ (dark blue, $\mathrm{N}_{\text {cell }} \geq 102$ ), $\Delta \mathrm{P}=-0.1 \mathrm{M}$ (blue, $\mathrm{N}_{\text {cell }} \geq 54$ ) and $\Delta \mathrm{P}=-0.2 \mathrm{M}$ (light blue, $\mathrm{N}_{\text {cell }} \geq 83$ ). $\mathrm{B}$ ) Same as $(\mathrm{A})$ but with pil1 $\Delta$ protoplasts and hypotonic shocks of $\triangle \mathrm{P}=-0.025 \mathrm{M}$ (dark red, $N_{\text {cell }} \geq 70$ ), $\Delta P=-0.05 \mathrm{M}$ (red, $N_{\text {cell }} \geq 103$ ) and $\Delta P=-0.1 \mathrm{M}$ (light red, $N_{\text {cell }} \geq 78$ ). (A) and (B) insets: relative volume increase after the hypotonic shocks (the volume at steady state is used as a reference). The number of cells used for each condition and each time point is given in Supplemental Table 11. The number of cells measured in the insets are the same as in the main figures. (A) and (B): error bars are standard errors of the mean. The number of cells used for each condition and each time point is given in Supplemental Table 13. 
bioRxiv preprint doi: https://doi.org/10.1101/342030; this version posted January 27, 2021. The copyright holder for this preprint (which was not certified by peer review) is the author/funder, who has granted bioRxiv a license to display the preprint in perpetuity. It is made available under

A)
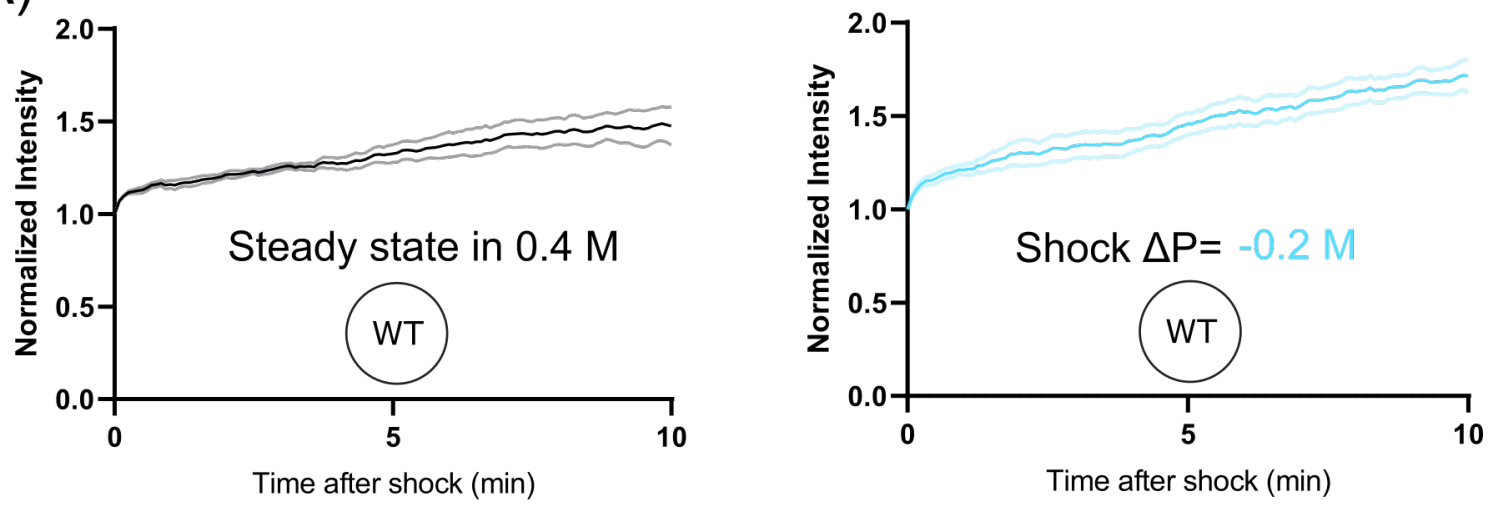

B)
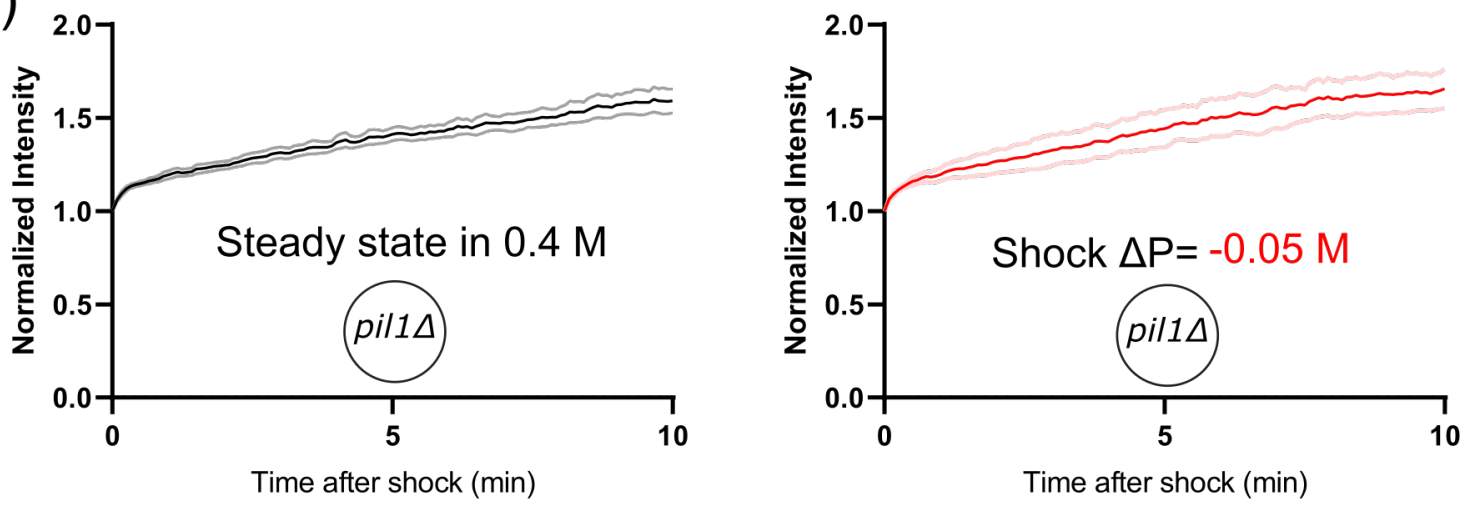

C)
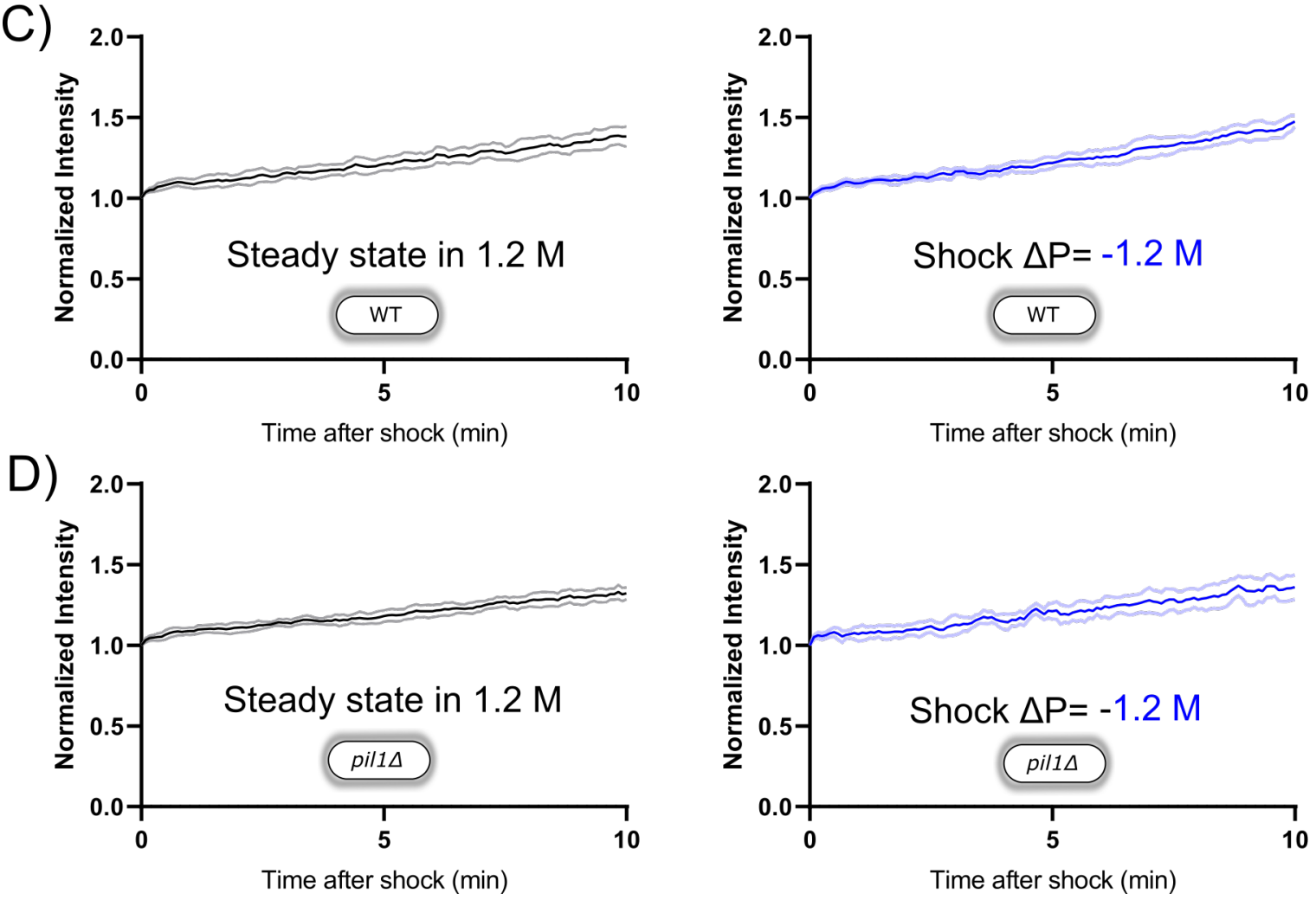

Figure 8 - Supplement 1: Separate plots for each condition in Figure 8. Rates of exocytosis at steady state and after hypotonic shocks. A) and B) The exocytic rate of wild-type and pil1 $\Delta$ protoplasts increases after a $\Delta P=-0.2 \mathrm{M}$ (black, before shock, $\mathrm{N}_{\text {cells }}=20$; light blue, after shock, $\mathrm{N}_{\text {cells }}=37 ; 4$ replicates each) and $\Delta \mathrm{P}=-0.05 \mathrm{M}$ (black, before shock, $\mathrm{N}_{\text {cells }}=44$; red, after shock, $\mathrm{N}_{\text {cells }}=60$; 4 replicates each) acute hypotonic 
bioRxiv preprint doi: https://doi.org/10.1101/342030; this version posted January 27, 2021. The copyright holder for this preprint (which was not certified by peer review) is the author/funder, who has granted bioRxiv a license to display the preprint in perpetuity. It is made available under

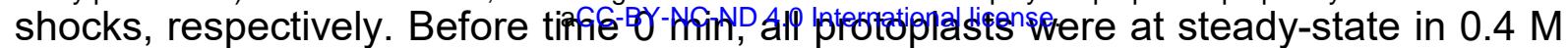
sorbitol. C) and D) The exocytic rate of wild-type walled cells is not changed after a $\triangle \mathrm{P}=-1.2 \mathrm{M}$ acute hypotonic shock (black, before shock, $\mathrm{N}_{\text {cells }}=79$; blue, after shock, $\mathrm{N}_{\text {cells }}=68 ; 3$ replicates each). The exocytic rate of pil1 $\Delta$ walled cells does not change significantly in the same conditions (black, before shock, $\mathrm{N}_{\text {cells }}=60$; blue, after shock, $\mathrm{N}_{\text {cells }}=96 ; 3$ replicates each). All walled cells were at steady-state in $1.2 \mathrm{M}$ sorbitol before time 0 min. (A)-(E) Dark color: mean; light color: standard error of the mean.

Steady state in $0.4 \mathrm{M}$

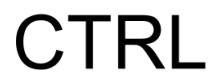

LatA

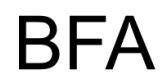

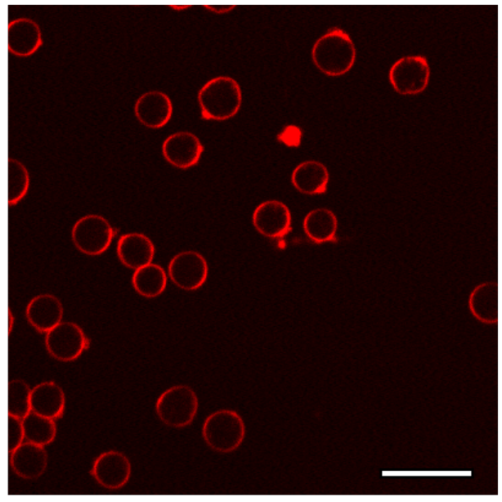
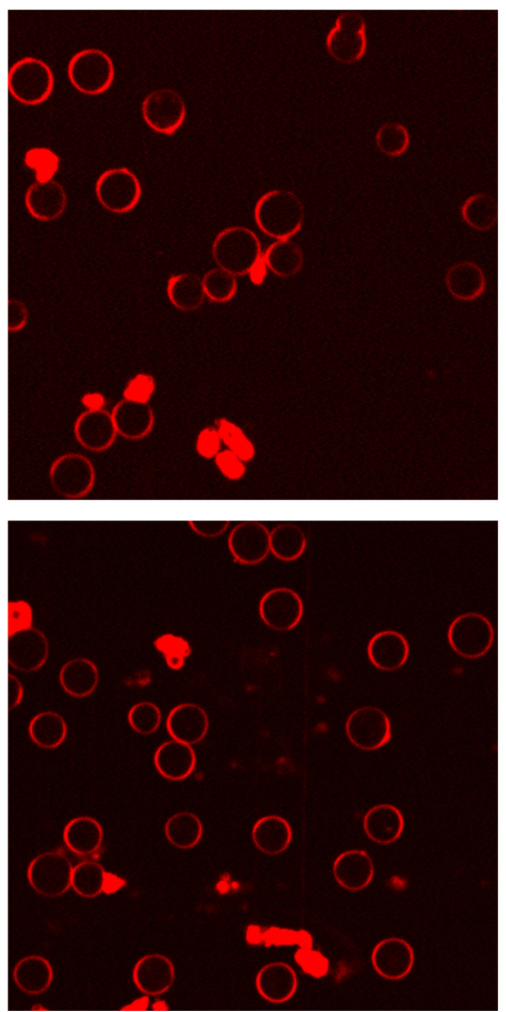

10 minutes after $\Delta \mathrm{P}=-0.2 \mathrm{M}$ shock
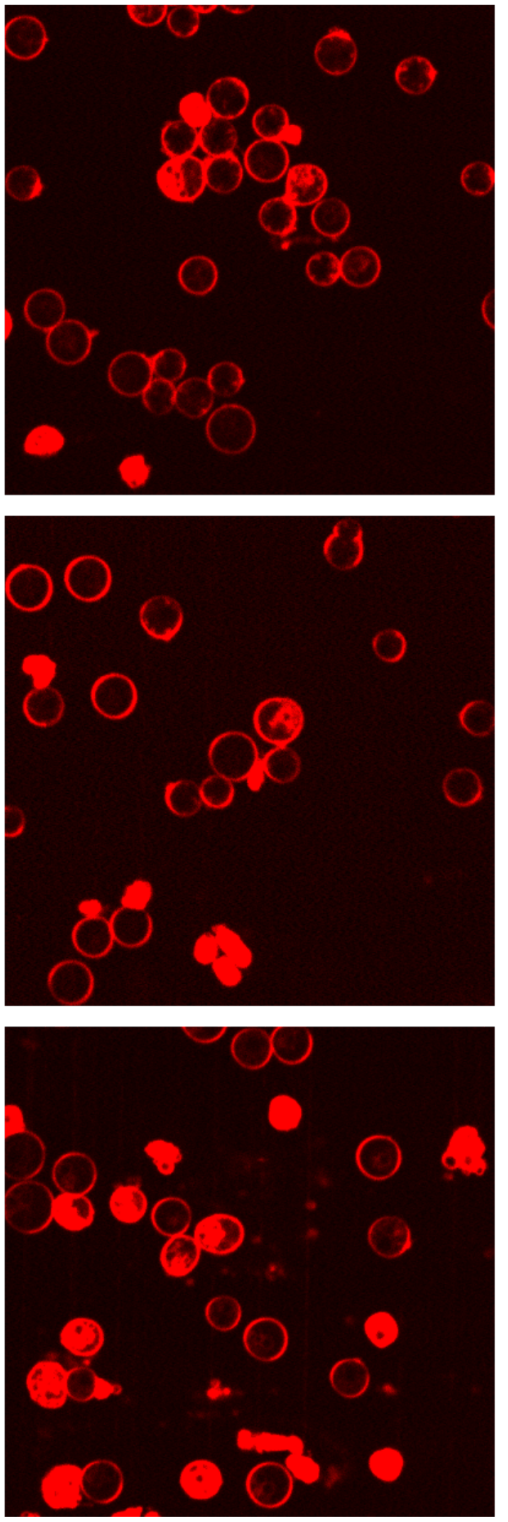
bioRxiv preprint doi: https://doi.org/10.1101/342030; this version posted January 27, 2021. The copyright holder for this preprint (which was not certified by peer review) is the author/funder, who has granted bioRxiv a license to display the preprint in perpetuity. It is made available under

Figure 9 Supplemental 1: Typical fields of view of pil1 $\Delta$ protoplasts at steady state in $0.4 \mathrm{M}$ sorbitol (left panel) and 10 minutes (right panel) after a $\Delta P=-0.2 \mathrm{M}$ hypotonic shock. First row: control, second row: latrunculin A, third row: Brefeldin A. Cells are considered dead if they contain large amounts of intracellular red fluorescence from the FM4-64 dye, which is the consequence of a rupture of the plasma membrane. Scale bar: $10 \mu \mathrm{m}$. 
bioRxiv preprint doi: https://doi.org/10.1101/342030; this version posted January 27, 2021. The copyright holder for this preprint (which was not certified by peer review) is the author/funder, who has granted bioRxiv a license to display the preprint in perpetuity. It is made available under

Supplemental tables

Supplemental Table 1: Yeast strains

\begin{tabular}{|c|c|c|}
\hline Strain & Genotype & Mating type \\
\hline SpJB57 & $\begin{array}{c}\text { fim1-mEGFP-NatMX6 ade6-M216 his3- } \Delta 1 \text { leu1-32 } \\
\text { ura4- } \Delta 18\end{array}$ & $\mathrm{~h}+$ \\
\hline SpJB204 & $\begin{array}{c}\text { pil1-mEGFP-kanMX6 ade6-M216 his3- } \Delta 1 \text { leu1-32 } \\
\text { ura4- } \Delta 18\end{array}$ & $\mathrm{~h}$ - \\
\hline SpJB234 & $\begin{array}{c}\text { pil1 } \Delta \text { fim1-mEGFP-NatMX6 ade6-M216 his3- } \Delta 1 \\
\text { leu1-32 ura4- } \Delta 18\end{array}$ & $\mathrm{~h}-$ \\
\hline SpJB566 & $\begin{array}{c}\text { mScarlet-I-end4 mEGFP-fim1 fex1 } \Delta \text { fex2 } \Delta \text { ade6- } \\
\text { M216 his3-D1 leu1-32 ura4-D18 }\end{array}$ & $\mathrm{h}-$ \\
\hline
\end{tabular}

Supplemental Table 2: Number of endocytic events used to generate Figures $1 \mathrm{~F}$ and $1 \mathrm{G}$

\begin{tabular}{|c|c|}
\hline Field of view & Number of tracks \\
\hline Field 1 & 64 \\
\hline Field 2 & 79 \\
\hline Field 3 & 91 \\
\hline Field 4 & 202 \\
\hline
\end{tabular}

Supplemental Table 3: Number of endocytic events used to generate Figure 2B

\begin{tabular}{|c|c|}
\hline $\begin{array}{c}\text { Sorbitol } \\
\text { concentration }\end{array}$ & Number of tracks \\
\hline $0 \mathrm{M}$ & 388 \\
\hline $0.8 \mathrm{M}$ & 454 \\
\hline $1.2 \mathrm{M}$ & 451 \\
\hline
\end{tabular}

Supplemental Table 4: Number of endocytic events used to generate Figure 2E

\begin{tabular}{|c|c|}
\hline Time point & Number of tracks \\
\hline Steady state & 354 \\
\hline 0 min & 103 \\
\hline 2 min & 169 \\
\hline 4 min & 190 \\
\hline 6 min & 153 \\
\hline
\end{tabular}


Supplemental Table 5: Number of endocytic events used to generate Figure 3B

\begin{tabular}{|c|c|}
\hline $\begin{array}{c}\text { Sorbitol } \\
\text { concentration }\end{array}$ & Number of tracks \\
\hline $0 \mathrm{M}$ & 342 \\
\hline $0.8 \mathrm{M}$ & 516 \\
\hline $1.2 \mathrm{M}$ & 514 \\
\hline
\end{tabular}

Supplemental Table 6: Number of endocytic events used to generate Figure 3D

\begin{tabular}{|c|c|}
\hline Time point & Number of tracks \\
\hline Steady state & 583 \\
\hline 0 min & 176 \\
\hline 2 min & 145 \\
\hline 4 min & 326 \\
\hline
\end{tabular}

Supplemental Table 7: Number of endocytic events used to generate Figures 4F and $4 G$

\begin{tabular}{|c|c|c|}
\hline $\begin{array}{c}\text { Sorbitol } \\
\text { concentration }\end{array}$ & $\begin{array}{c}\text { Number of } \\
\text { tracks } \\
\text { WT cells }\end{array}$ & $\begin{array}{c}\text { Number of tracks } \\
\text { pil1 } \mathbf{\Delta} \text { cells }\end{array}$ \\
\hline Protoplasts in 1.2 M & 143 & 203 \\
\hline Protoplasts in 0.8 M & 151 & 184 \\
\hline Protoplasts in 0.4 M & 682 & 166 \\
\hline Protoplasts in 0.25 M & 395 & 370 \\
\hline WT walled cells in 0M & 234 & 300 \\
\hline
\end{tabular}


bioRxiv preprint doi: https://doi.org/10.1101/342030; this version posted January 27, 2021. The copyright holder for this preprint (which was not certified by peer review) is the author/funder, who has granted bioRxiv a license to display the preprint in perpetuity. It is made available under

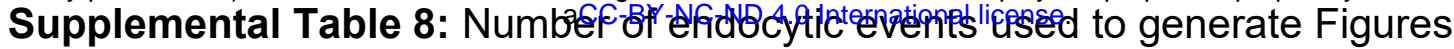

$5 \mathrm{C}$ and $5 \mathrm{~F}$

$\Delta \mathrm{P}=-0.05 \mathrm{M}$

\begin{tabular}{|c|c|c|}
\hline Time point & $\begin{array}{c}\text { Number of tracks } \\
\text { WT cells }\end{array}$ & $\begin{array}{c}\text { Number of tracks } \\
\text { pil1 } \Delta \text { cells }\end{array}$ \\
\hline Steady state in $0.4 \mathrm{M}$ & 279 & 429 \\
\hline 0 min after $\Delta \mathrm{P}=-0.05 \mathrm{M}$ & 193 & 183 \\
\hline 10 min after $\Delta \mathrm{P}=-0.05 \mathrm{M}$ & 182 & 206 \\
\hline
\end{tabular}

$\Delta P=-0.1 M$

\begin{tabular}{|c|c|c|}
\hline Time point & $\begin{array}{c}\text { Number of tracks } \\
\text { WT cells }\end{array}$ & $\begin{array}{c}\text { Number of tracks } \\
\text { pil1 } \mathbf{\Delta} \text { cells }\end{array}$ \\
\hline Steady state in $0.4 \mathrm{M}$ & 413 & 95 \\
\hline 0 min after $\Delta \mathrm{P}=-0.1 \mathrm{M}$ & 190 & 215 \\
\hline 10 min after $\Delta \mathrm{P}=-0.1 \mathrm{M}$ & 186 & $\emptyset$ \\
\hline
\end{tabular}

$\Delta P=-0.2 M$

\begin{tabular}{|c|c|c|}
\hline Time point & $\begin{array}{c}\text { Number of tracks } \\
\text { WT cells }\end{array}$ & $\begin{array}{c}\text { Number of tracks } \\
\text { pil1 } \Delta \text { cells }\end{array}$ \\
\hline Steady state in $0.4 \mathrm{M}$ & 269 & 95 \\
\hline 0 min after $\Delta \mathrm{P}=-0.2 \mathrm{M}$ & 396 & 373 \\
\hline 10 min after $\Delta \mathrm{P}=-0.2 \mathrm{M}$ & 309 & $\varnothing$ \\
\hline
\end{tabular}

Supplemental Table 9: Number of endocytic events used to generate Figure 5D and 5G

\begin{tabular}{|c|c|}
\hline Time point & $\begin{array}{c}\text { Number of tracks } \\
\text { WT cells }\end{array}$ \\
\hline Steady state in $0.4 \mathrm{M}$ & 269 \\
\hline 0 min after $\Delta P=-0.2 \mathrm{M}$ & 396 \\
\hline 2 min after $\Delta P=-0.2 \mathrm{M}$ & 124 \\
\hline 4 min after $\Delta P=-0.2 \mathrm{M}$ & 127 \\
\hline 6 min after $\Delta P=-0.2 \mathrm{M}$ & 178 \\
\hline 8 min after $\Delta P=-0.2 \mathrm{M}$ & 255 \\
\hline 10 min after $\Delta P=-0.2 \mathrm{M}$ & 309 \\
\hline
\end{tabular}


bioRxiv preprint doi: https://doi.org/10.1101/342030; this version posted January 27, 2021. The copyright holder for this preprint (which was not certified by peer review) is the author/funder, who has granted bioRxiv a license to display the preprint in perpetuity. It is made available under

\begin{tabular}{|c|c|}
\hline Time point & 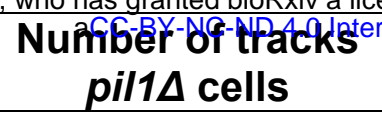 \\
\hline Steady state in $0.4 \mathrm{M}$ & 429 \\
\hline 0 min after $\Delta P=-0.05 M$ & 183 \\
\hline 2 min after $\Delta \mathrm{P}=-0.05 \mathrm{M}$ & 188 \\
\hline 4 min after $\Delta P=-0.05 M$ & 162 \\
\hline 6 min after $\Delta P=-0.05 M$ & 193 \\
\hline $8 \mathrm{~min}$ after $\Delta \mathrm{P}=-0.05 \mathrm{M}$ & 197 \\
\hline 10 min after $\Delta P=-0.05 M$ & 206 \\
\hline
\end{tabular}

Supplemental Table 10: Number of endocytic events used to generate Figures $5 \mathrm{H}$ and 51

\begin{tabular}{|c|c|c|}
\hline Time point & $\begin{array}{c}\text { Number of tracks } \\
\text { WT cells }\end{array}$ & $\begin{array}{c}\text { Number of tracks } \\
\text { pil1 } \Delta \text { cells }\end{array}$ \\
\hline Steady state in $0.25 \mathrm{M}$ & 226 & 182 \\
\hline 0 min after $\Delta \mathrm{P}=-0.1 \mathrm{M}$ & 75 & 67 \\
\hline
\end{tabular}

Supplemental Table 11: Number of cells used to generate Figures 7A and 7B

$\Delta \mathrm{P}=-\mathbf{0 . 0 2 5 M}$

\begin{tabular}{|c|c|c|}
\hline Time point & $\begin{array}{c}\text { Number of cells } \\
\text { WT cells }\end{array}$ & $\begin{array}{c}\text { Number of cells } \\
\text { pil1 } \Delta \text { cells }\end{array}$ \\
\hline Steady state in $0.4 \mathrm{M}$ & $\varnothing$ & 99 \\
\hline 0 min after $\Delta P=-0.025 \mathrm{M}$ & $\varnothing$ & 100 \\
\hline 2 min after $\Delta P=-0.025 \mathrm{M}$ & $\varnothing$ & 71 \\
\hline 4 min after $\Delta P=-0.025 \mathrm{M}$ & $\varnothing$ & 70 \\
\hline 6 min after $\Delta P=-0.025 \mathrm{M}$ & $\varnothing$ & 98 \\
\hline 8 min after $\Delta P=-0.025 \mathrm{M}$ & $\varnothing$ & 118 \\
\hline 10 min after $\Delta P=-0.025 \mathrm{M}$ & $\varnothing$ & 96 \\
\hline
\end{tabular}

$\Delta \mathrm{P}=-0.05 \mathrm{M}$

\begin{tabular}{|c|c|c|}
\hline Time point & $\begin{array}{c}\text { Number of cells } \\
\text { WT cells }\end{array}$ & $\begin{array}{c}\text { Number of cells } \\
\text { pil1 } \Delta \text { cells }\end{array}$ \\
\hline Steady state in $0.4 \mathrm{M}$ & 172 & 263 \\
\hline 0 min after $\Delta P=-0.05 \mathrm{M}$ & 102 & 106 \\
\hline 2 min after $\Delta P=-0.05 \mathrm{M}$ & 117 & 111 \\
\hline 4 min after $\Delta P=-0.05 \mathrm{M}$ & 114 & 106 \\
\hline 6 min after $\Delta P=-0.05 \mathrm{M}$ & 113 & 103 \\
\hline 8 min after $\Delta P=-0.05 \mathrm{M}$ & 124 & 123 \\
\hline 10 min after $\Delta P=-0.05 \mathrm{M}$ & $\varnothing$ & 104 \\
\hline
\end{tabular}


bioRxiv preprint doi: https://doi.org/10.1101/342030; this version posted January 27, 2021. The copyright holder for this preprint (which was not certified by peer review) is the author/funder, who has granted bioRxiv a license to display the preprint in perpetuity. It is made available under

$\Delta \mathrm{P}=-\mathbf{0 . 1 M}$

\begin{tabular}{|c|c|c|}
\hline Time point & $\begin{array}{c}\text { Number of cells } \\
\text { WT cells }\end{array}$ & $\begin{array}{c}\text { Number of cells } \\
\text { pil1 } \mathbf{\text { cells }}\end{array}$ \\
\hline Steady state $0.4 \mathrm{M}$ & 127 & 151 \\
\hline 0 min after $\Delta \mathrm{P}=-0.1 \mathrm{M}$ & 62 & 125 \\
\hline 2 min after $\Delta \mathrm{P}=-0.1 \mathrm{M}$ & 70 & 78 \\
\hline 4 min after $\Delta \mathrm{P}=-0.1 \mathrm{M}$ & 78 & $\emptyset$ \\
\hline 6 min after $\Delta \mathrm{P}=-0.1 \mathrm{M}$ & 62 & $\emptyset$ \\
\hline 8 min after $\Delta \mathrm{P}=-0.1 \mathrm{M}$ & 54 & $\varnothing$ \\
\hline
\end{tabular}

$\Delta \mathrm{P}=-\mathbf{0 . 2 M}$

\begin{tabular}{|c|c|c|}
\hline Time point & $\begin{array}{c}\text { Number of cells } \\
\text { WT cells }\end{array}$ & $\begin{array}{c}\text { Number of cells } \\
\text { pil1 } \mathbf{\Delta} \text { cells }\end{array}$ \\
\hline Steady state $0.4 \mathrm{M}$ & 146 & $\varnothing$ \\
\hline 0 min after $\Delta \mathrm{P}=-0.2 \mathrm{M}$ & 149 & $\varnothing$ \\
\hline 2 min after $\Delta \mathrm{P}=-0.2 \mathrm{M}$ & 158 & $\emptyset$ \\
\hline 4 min after $\Delta \mathrm{P}=-0.2 \mathrm{M}$ & 83 & $\varnothing$ \\
\hline 6 min after $\Delta \mathrm{P}=-0.2 \mathrm{M}$ & 107 & $\emptyset$ \\
\hline 8 min after $\Delta \mathrm{P}=-0.2 \mathrm{M}$ & 83 & $\varnothing$ \\
\hline
\end{tabular}

Supplemental Table 12: Number of cells used to generate Figure 7C

\begin{tabular}{|c|c|c|}
\hline Time point & $\begin{array}{c}\text { Number of cells } \\
\text { WT cells }\end{array}$ & $\begin{array}{c}\text { Number of cells } \\
\text { pil1 } \mathbf{\text { cells }}\end{array}$ \\
\hline Steady state 1.2M & 62 & 119 \\
\hline 0 min after $\Delta \mathrm{P}=-1.2 \mathrm{M}$ & 82 & 69 \\
\hline 2 min after $\Delta \mathrm{P}=-1.2 \mathrm{M}$ & 77 & 44 \\
\hline 4 min after $\Delta \mathrm{P}=-1.2 \mathrm{M}$ & 67 & 67 \\
\hline 6 min after $\Delta \mathrm{P}=-1.2 \mathrm{M}$ & 66 & $\varnothing$ \\
\hline
\end{tabular}

Supplemental Table 13: Number of cells used to generate Figure 7D

\begin{tabular}{|c|c|c|}
\hline $\begin{array}{c}\text { Sorbitol } \\
\text { Concentration }\end{array}$ & $\begin{array}{c}\text { Number of cells } \\
\text { WT cells }\end{array}$ & $\begin{array}{c}\text { Number of cells } \\
\text { pil1 } \mathbf{\Delta} \text { cells }\end{array}$ \\
\hline Steady state in 0 M & 240 & 188 \\
\hline Steady state in $0.8 \mathrm{M}$ & 103 & 105 \\
\hline Steady state in 1.2 M & 159 & 183 \\
\hline Steady state in $2 \mathrm{M}$ & 161 & 80 \\
\hline
\end{tabular}

